\title{
Waldeyer's ring equivalent lymphoid tissue in the rat : a model for studying the immunological role of nose associated lymphoid tissue
}

Citation for published version (APA):

Koornstra, P. (1997). Waldeyer's ring equivalent lymphoid tissue in the rat : a model for studying the immunological role of nose associated lymphoid tissue. [Doctoral Thesis, Maastricht University]. Universiteit Maastricht. https://doi.org/10.26481/dis.19970905pk

Document status and date:

Published: 01/01/1997

DOI:

10.26481/dis.19970905pk

Document Version:

Publisher's PDF, also known as Version of record

Please check the document version of this publication:

- A submitted manuscript is the version of the article upon submission and before peer-review. There can be important differences between the submitted version and the official published version of record.

People interested in the research are advised to contact the author for the final version of the publication, or visit the DOI to the publisher's website.

- The final author version and the galley proof are versions of the publication after peer review.

- The final published version features the final layout of the paper including the volume, issue and page numbers.

Link to publication

\footnotetext{
General rights rights.

- You may freely distribute the URL identifying the publication in the public portal. please follow below link for the End User Agreement:

www.umlib.nl/taverne-license

Take down policy

If you believe that this document breaches copyright please contact us at:

repository@maastrichtuniversity.nl

providing details and we will investigate your claim.
}

Copyright and moral rights for the publications made accessible in the public portal are retained by the authors and/or other copyright owners and it is a condition of accessing publications that users recognise and abide by the legal requirements associated with these

- Users may download and print one copy of any publication from the public portal for the purpose of private study or research.

- You may not further distribute the material or use it for any profit-making activity or commercial gain

If the publication is distributed under the terms of Article $25 \mathrm{fa}$ of the Dutch Copyright Act, indicated by the "Taverne" license above, 


\title{
WALDEYER'S RING EQUIVALENT LYMPHOID TISSUE IN THE RAT
}

\author{
A model for studying the immunological role of \\ nose associated lymphoid tissue
}


Printing: Benda Drukkers, Nijmegen

CIP-gegevens Koninklijke Bibliotheek, "s-Gravenhage Koornstra, Petra Jacoba

Waldeyer's Ring Equivalent lymphoid tissue in the rat

Proefschrift Maastricht-Met samenvatting in het Nederlands-Met literatuuropgave

ISBN: $90-9010856-4$

Trefwoorden: Waldeyer's Ring, Tonsil, Immunology, Lymphoid tissue, Lymphoid cell recirculation 


\title{
WALDEYER'S RING EQUIVALENT LYMPHOID TISSUE IN THE RAT
}

\author{
A model for studying the immunological role of \\ nose associated lymphoid tissue
}

\section{PROEFSCHRIFT}

ter verkrijging van de graad van doctor aan de Universiteit Maastricht op

gezag van de Rector Magnificus, Prof. mr. M. J. Cohen,

volgens het besluit van het College van Decanen, in het openbaar te verdedigen

op vrijdag 5 september 1997 om 14.00 uur

door

Petra Koornstra 


\section{Promotores:}

Prof, dr. P.J.C. van Breda Vriesman

Prof. dr. E.H.M.A. Marres

\section{Copromotores:}

Dr. F.I.C.R.S. de Jong

Dr. A.M. Duijvestijn

\section{Beoordelingscommissie:}

Prof. dr. J.W. Arends (Voorzitter)

Prof. dr. J. Drukker

Dr. W. Kuijpers (Katholieke Universiteit Nijmegen)

Prof. dr. J.J. Manni

Prof. dr. T. Sminia (Vrije Universiteit Amsterdam)

Publication of this thesis was financially supported by:

Abbott, Smithkline Beecham 
Jer nagedachtonis aan mijn vador on $\mathcal{L}_{00}$ Aan mijn moeder. Voor Rolf, Barbara en Bas 


\section{Contents}

$\begin{array}{ll}\text { Abbreviations } & 8\end{array}$

Introduction to the chapters $\quad 11$

$\begin{array}{lll}\text { Chapter } 1 & \text { General introduction } & 15\end{array}$

Chapter 2 Anatomy and surgical approach of the Waldeyer ring equivalent lymphoid tissue in the rat

Chapter 3 Immunohistology of nasopharyngeal (Waldeyer's ring equivalent) lymphoid tissue in the rat

Chapter 4

Chapter 5

Chapter 6

Epilogue

The Waldeyer ring equivalent in the rat. A Model for Analysis of Oronasopharyngeal Immune Responses

69

Tonsillar (Waldeyer's ring equivalent) lymphoid tissue in the Rat: Lymphocyte Subset Binding to High Endothelial Venules (HEV) and In Situ Distribution

Summary

Samenvatting

Dankwoord

Curriculum vitae 


\section{Abbreviations}

$\begin{array}{ll}\text { Ag } & \text { antigen } \\ \text { AFC } & \text { antibody forming cell } \\ \text { APC } & \text { antigen presenting cell } \\ \text { BALT } & \text { bronchus associated lymphoid tissue } \\ \text { BrdU } & \text { bromodesoxyuridine } \\ \text { BSA } & \text { bovine serum albumin } \\ \text { CD } & \text { cluster of differentiation } \\ \text { CLN } & \text { cervical lymph node } \\ \text { Cpm } & \text { counts per minute } \\ \text { DCLN } & \text { deep cervical lymph node } \\ \text { EPO } & \text { endogenous peroxidase } \\ \text { ET } & \text { Eustachian tube } \\ \text { FACS } & \text { fluorescein activated cell sorter } \\ \text { FCS } & \text { fetal calf serum } \\ \text { FDC } & \text { follicular dendritic cell } \\ \text { GC } & \text { germinal center } \\ \text { HBSS } & \text { Hanks balanced salt solution } \\ \text { HE } & \text { hematoxylin eosin } \\ \text { HEV } & \text { high endothelial venules } \\ \text { IDC } & \text { interdigitating (dendritic) cell } \\ \text { Ig } & \text { immunoglobulin } \\ \text { MadCAM } & \text { mucosal addressin cell adhesion molecule } \\ \text { MALT } & \text { mucosa associated lymphoid tissue } \\ \text { MHC } & \text { major histocompatibility complex } \\ \text { MOAb } & \text { monoclonal antibody } \\ \text { M cell } & \text { microfold epithelial cell } \\ \text { MLN } & \text { mesenteric lymph node } \\ \text { Mpli } & \text { macrophage } \\ \text { NALT } & \text { nose associated lymphoid tissue } \\ \text { PBS } & \text { phosphate buffered saline } \\ \text { PCLN } & \text { posterior cervical lymph node } \\ \text { PP } & \text { Peyer"s patch } \\ \text { RECA } & \text { rat endothelial cell antigen } \\ \text { RPM } & \text { rates/rounds per minutes } \\ \text { SCLN } & \text { superior cervical lymph node } \\ \text { SD } & \text { standard deviation } \\ \text { SF } & \text { sublimate formol fixative } \\ \text { SIgA } & \text { secretory immunoglobulin A } \\ \text { TCR } & \text { T cell receptor } \\ \text { WR } & \text { Waldeyer's ring } \\ \text { WRE } & \text { Waldeyer's ring equivalent } \\ \text { W/v } & \text { weight/volume } \\ & \end{array}$




\section{INTRODUCTION}

TO THE

\section{CHAPTERS}




\section{Introduction to the chapters}

The motive for the research presented in this thesis originated from a joint interest in the role of adenotonsillar tissues of the Department of Otorhinolaryngology from the Academic Hospital Maastricht and the Department of Immunology from the University Maastricht. Both departments felt the need to study these lymphoid tissues in immunological terms in a suitable experimental model. To allow detailed immunological studies in such an animal model, it is essential that the chosen species is immunologically well defined and inbred strains are available. For these reasons the rat was chosen as the experimental animal. In man the lymphoid tissues of the oronasopharynx are collectively called the Waldeyer ring (WR). In the rat no WR like organization of lymphoid tissue was found, but serial sectioning of the head revealed bilaterally located lymphoid tissue in the nasopharyngeal duct. The studies presented in this thesis deal with these nose associated lymphoid tissues or organs in the rat, which we originally, rather prematurely, called the Waldeyer ring equivalent (WRE). In more recent scientific correspondence these organs are called the nasal associated lymphoid tissue, or NALT.

Chapter $l$ is a review of the literature of lymphoid tissue emphasizing NALT/WRE. It derives from a joint effort with the Department of Pathology, National Institute of Public Health and Environmental Protection, Bilthoven, and the Department of Cell Biology, Free University of Amsterdam.

Chapter 2 describes the anatomical work. Here the localization, epithelial lining, the involution upon ageing, blood supply and lymph drainage of the NALT/WRE is described. The new surgical approach we developed for exploring and harvesting the WRE is demonstrated in detail.

Chapter 3 describes the immunohistolgy of NALT/WRE. The compartmentalization and distribution in situ of various immunologically relevant lymphoid and non Jymphoid cells in this mucosa associated lymphoid tissue is studied.

Chapter 4 describes in vivo experiments regarding migratory characteristics of lymphocytes from NALT/WRE to other lymphoid organs, and vice versa. Also the lymph drainage from NALT/WRE to local lymph nodes is studied. To define wether in NALT/WRE lymplocyte entrance from the blood occurred through so called high endothelial venules (HEV), the tissue is examined ultra structurally for the presence of these specialized blood vessels.

Chapter 5 addresses, in the context of lymphocyte migration, the adherence of lymphocytes to HEV in the NALT/WRE, using a specialized in vitro method. In order to acquire this technique that allows to measure adherence of lymphocytes to $\mathrm{HEV}$ in frozen sections of lymphoid tissue, a collaborative effort was started with Professor J.J. Woodruff, NY Downstate University. This method, with some modifications according to Dr. E.C. Butcher (Stanford University, Palo Alto), is used to compare the adherence of lymphocyte subsets to HEV between NALT/WRE and other lymphoid tissues. In addition, FACS 
analysis is performed to study the in situ distribution profiles of lymphocyte subsets in NALT/WRE.

Chapter 6 , in the epilogue, features of the human oronasopharyngeal lymphoid tissue are viewed in relation to models, including the present study.

The summary recapitulates the content of the individual chapters. 


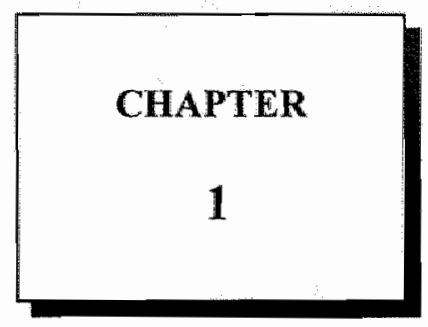

\section{General introduction}

\section{Adapted from: \\ THE ROLE OF NASOPHARYNGEAL LYMPHOID TISSUE}

C.F. Kuper', P.J.Koornstra ${ }^{2}$, D.M.H. Hameleers ${ }^{3}$, J. Biewenga ${ }^{3}$, B.J. Spit ${ }^{4}$, A.M. Duijvestijn ${ }^{5}$, P.J.C. van Breda Vriesman ${ }^{5}$, T. Sminia

1 Laboratory of Pathology, National Institute of Public Health and Environmental Protection, Bilthoven

2 Department of Otorhinolaryngology, Academic Hospital, Maastricht

3 Department of Histology, Medical Faculty, Vrije Universiteit , Amsterdam

" TNO-ITV Department of Toxicology and Nutrition, Zeist

5 Department of Immunology, University of Limburg, Maastricht, Maastricht

Immunol Today $1992 ; 13,6: 219-224$ 


\section{Introduction}

In man, the tonsils are the most conspicuous lymphoid tissues in the oro- and nasopharynx. These structures are best known from adenotonsillectomy, frequently carried out in young children who suffer from recurrent tonsillitis or obstructive hypertrophic tonsils. Both conditions can be associated with severe clinical problems, such as hypoxemia and cardio pulmonary changes $(1,2,3,4)$. Patients mostly benefit from such a surgical intervention. However, the tonsils are immunological organs. Consequently, adenotonsillectomy may have repercussions on immune reactivity. Even to date, the precise immunological role of these lymphoid tissues is not fully clear, but it is most likely that they are essential in response to oro nasopharyngeal antigen from the external milieu. To understand the impact of nasal and oro nasopharyngeal lymphoid tissue on the immune system, it is needed to take a closer look at the oro nasopharyngeal lymphoid tissue in terms of location, structure, and function and its relation to other mucosa associated lymphoid tissues.

\section{Anatomy}

The internal milieu of human and animal species is in contact with the external milieu via the skin and mucosal membranes. In comparison to skin, the mucosal membranes form a weak mechanical barrier, but they are equipped with an extensive defence mechanism which in vertebrates comprises both nonspecific and specific elements.

The nasal mucosa is the first site of contact with inhaled antigens. However, the nature of local immune responses and the role of nose associated lymphoid tissue (NALT) in those responses have rarely been studied, due to the absence of a suitable animal model. In man, the collection of oro nasopharyngeal lymphoid tissues is known as Waldeyer's ring (WR) (5). It consists of lymphoid cell agglomerations, situated directly underneath the mucosal epithelium of the oro nasopharynx. During ontogeny, these tissues develop at well-defined locations in the oro nasopharynx by infiltration and aggregation of lymphocytes. The various well defined lymphoid structures in the oro nasopharynx are: the single pharyngeal tonsil, the bilateral palatine tonsils, the lingual tonsil, tonsillar structures around the opening of the two Eustachian tubes, and scattered lymph follicles in the posterior pharyngeal wall. Fig. 1 gives a schematical presentation of the lymphoid tissue agglomerations that compose the human WR.

\section{Histology}

Various histological, immunohistological and lymphocyte phenotyping studies with human oro nasopharyngeal lymphoid tissues have been pertormed. The studies concern themselves with WR lymphoid tissue, in particular the pharyngeal tonsil, and the palatine tonsils, under healthy and diseased conditions (6-14). Few studies describe the lymphoid cell populations found in the mucosa of the nose $(15,16)$. The so called lympho epithelial tissue of the pharyngeal and palatine tonsil consists predominantly of lined B cell follicles, which contain germinal centres (GC) with B cell blasts, including plasma blasts. Between these B cell follicles small $\mathrm{T}$ cell areas are located, in which both CD4 T(helper) and CD8 T(cytotoxic/suppressor) cells are present, with a preponderance of CD4 cells. High endothelial venules (HEV) that are 


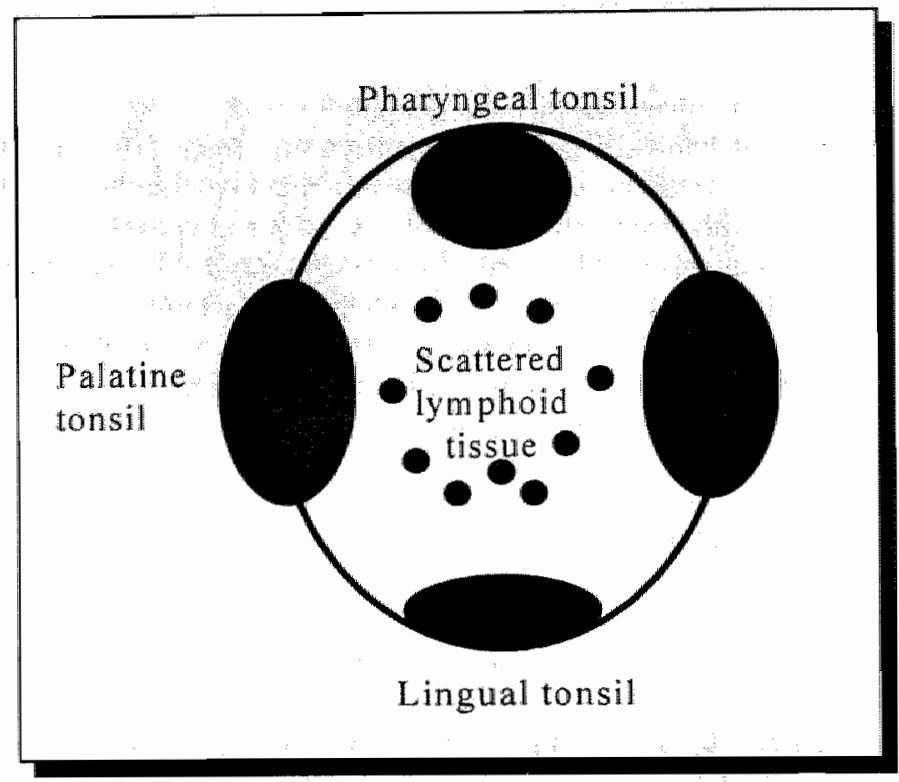

Fig.1. Schematic presentation of Waldeyer"s ring. (With permission of Dr. F.I.C.R.S. de Jong)

specialised to support immigration of blood lymphocytes into the tonsils are located in the $T$ cell areas. Most of the plasma cells found in the tissues are of the IgG and IgA isotype (17), followed to a lesser amount by $\operatorname{IgM}$ plasma cells. Only very few IgE plasma cells can be detected. Although IgG, IgA and IgM plasma cells are noticed in the GC, most of them are locatted in and near the epithelial and connective tissue structures of the tonsil away from these GC. Specialised antigen presenting cells, such as interdigitating dendritic cells and follicular dendritic cells are present in the T cell areas and germinal centres respectively. The lymphoid tissue of both the pharyngeal and the palatine tonsil is covered by an epithelial lining. The epithelial layer of the pharyngeal tonsil consists of pseudo stratified epithelium with cilia and secretory goblet cells similar to that in the nose. The palatine tonsil is covered with squamous stratified epithelium as found in the oral cavity and the pharynx. In contrast to the epithelium of the pharyngeal tonsil, the epithelial layer of the palatine tonsil shows deep crypts and is noticed as a lympho epithelial reticular layer as it is heavily infiltrated with lymphocytes. Various studies show that this WR lymphoid tissue belongs to the so-called mucosa associated lymphoid tissue (MALT) (6). MALT comprises defined lympho epithelial tissues or lymphoid cell agglomerations in organs that are directly related to the entrance and exit pathways of the body. In fig.2, a series of prominent organ systems containing lymphoid tissues belonging to MALT is presented. 


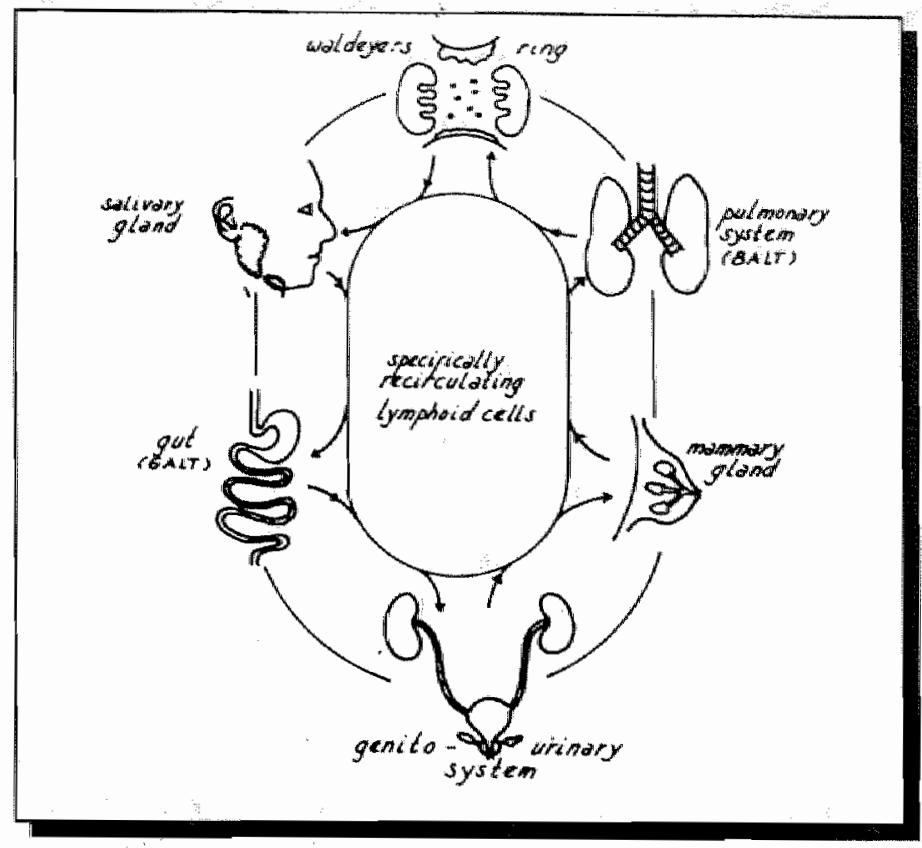

Fig.2. Artistic presentation of MALT.

(With permission of Dr. F.I.C.R.S. de Jong)

\section{Immunological functions of human tonsils}

Although little is known about the immunology of the WR lymphoid organs, indications for particular immunological functions of this oro-nasopharyngeal lymphoid tissue are obtained from clinical studies of certain diseases and from the effects of adenotonsillectomy. Decreased serum IgA levels are described after adenotonsillectomy. Although these studies are ambiguous with respect to the type of IgA that is affected, i.e. secretory or serum IgA, they indicate an important regulatory role of the tonsils in LgA production (18-23). IgA plasma cells are present in relatively great numbers in the tonsillar tissue and in vitro studies show a distinct production of monomeric IgA by tonsillar lymphocytes (24). That indeed tonsils are relevant for IgA production is observed in patients suffering from IgA nepluropathy. Among them tonsillectomy is a well known clinical intervention and leads to decreased serum $\lg A$ levels, and improvement of renal function $(25,26)$. These studies have suggested a role of oronasopharyngeal lymphoid tissue in IgA production and, in fact, recommend a thorough sudy on the IgA status of patients prior to adenotonsillectomy (27). From three studies $(28,29,30)$ in patients suffering from IgE mediated hypersensitivity, two describe a relation with tonsillar disease $(28,29)$ and point to a possible role of the tonsil in production of IgE relevant to disease. In other clinical studies, a relation between tonsillar function and rheumatoid arthritis (31) and between tonsillar function and Hodgkin's disease $(32,33)$ have been explored. 
However, these studies give controversial results about a particular tonsillar immunological role in these diseases. That indeed WR lymphoid tissue is essential for immunity to inhalation antigens is suggested by the increasing incidence of recurrent airway infections and airway hyper responsiveness (34). This was thought to be a result from deleterious effects of air pollution on mucosal WR structures: More recently however, it is considered that the increase of airway diseases is associated with or caused by pathogenic inhalation antigens, such as mite products, as a result of insulation of houses. Although conclusive evidence on the causes of increasing airway diseases has not been given so far, it becomes more and more clear that an adequate oro-nasopharyngeal immune system is essential in averting diseases of the upper airway.

\section{Animal tissue equivalents to the ring of Waldeyer}

Tissues equivalent to Waldeyer's ring have been found in monkeys $(35,36)$, horses $(37,38)$ and cattle (39), but no functional studies have been performed in these species. It was long thought that rodents do not possess tonsillar tissue although, decades ago, paired lymphoid cell agglomerations were described in the nasal passages of the rat (40). Reciently Belal et al. (41) and lchimiya et al. (42) have reported the presence of such aggregates in mice. Recent approaches have been made to study NALT/WRE in the rat (43-49) and mouse (50). These studies have demonstrated that the lymphoid cell accumulations, situated at the entrance of the nasopharyngeal duct, are a component of the MALT. Although cross-sections of the nasal passages show lymphoid accumulations elsewhere, the above mentioned paired tissue is probably the only well organised MALT in the nose of rodents that has a fixed location. Since NALT/WRE is a mucosa associated lymphoid tissue, it is essential to compare functions of NALT/WRE with those of other defined mucosa associated lymphoid tissues such as that in the lower respiratory tract (Bronchus Associated Lymphoid Tissue (BALT)) and in the gut (Peyer's patches (PP)).

\section{Comparison of NALT/WRE with other MALT structure}

NALT/WRE has a more activated appearance than BALT in conventionally housed, untreated rats i.e. better developed follicles and marked intra epithelial infiltration by leukocytes in NALT/WRE (48) (see Table 1 and Fig. 3). It is also found earlier in ontogeny than BALT (43). The more activated appearance and earlier development of NALT/WRE are probably due to its strategic position i.e. first contact with respect to incoming air (containing aero antigens).

Rats breathe through the nose so the inspired air always passes the nasal cavities before it reaches the lungs. NALT/WRE resembles PP with regard to ontogeny although PP appears shortly before bitth, earlier than NALT/WRE. This may reflect a more central rolle for PP in MALT or may simply result from the earlier exposure of the gut to an antigen. The activated appearance and the ontogeny of these MALT components suggest that NALT/WRE and PP are the main components in the defence of the respiratory tract and gut, respectively.

Although NALT/WRE and PP both appear to be important to the defence of mucosal sites, their mechanisms may differ. PP may be the central tissue in the induction of secretory 
PP

\section{Ontogeny}

Presence of tissue

birth

First lymphocytes

Distinct $T$ and $B$ areas

Day 10 after birth

Before birth

$\mathrm{T}$
NALT/WRE

At birth

$\mathrm{T}$

Day 10 after birth

\section{BALT}

Day 4 after $+t$

$+$

$++$

Membranous IgA

positive $B$ cells.

Tingible body

macrophages
Intraepithelial

leukocytes

Adult tissue

FDC in follicles

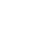

.

$++$

Table 1. Characteristics of PP, NALT/WRE and BALT in normal rats.

PP: Peyer's patch, NALT: nose associated lymphoid tissue, BALT: bronchus associated lymphoid tissue, FDC: follicular dendritic cell

References: Ontogeny: PP(71), NALT/WRE(43), BALT(69)

Adult tissue: PP(70), NALT/WRE(47,49), BALT(70), FDC(68)

immunoglobulin (Ig) synthesis, while the lymphoid tissues in the respiratory tract appear to be more involved in cellular responses. Even within the respiratory tract, MALT tissues differ: NALT/WRE and BALT differ in their state of activation and in the number of B cells that express membrane IgA (mIgA). The latter are rare in NALT/WRE but not in BALT $(51,52)$ and in this respect BALT resembles PP more closely than does NALT/WRE. The differences in distribution patterns of macrophage populations in NALT/WRE, BALT and PP (48) provide additional evidence of diwergent mechanisms for the different mucosal lymphoid tissues. 


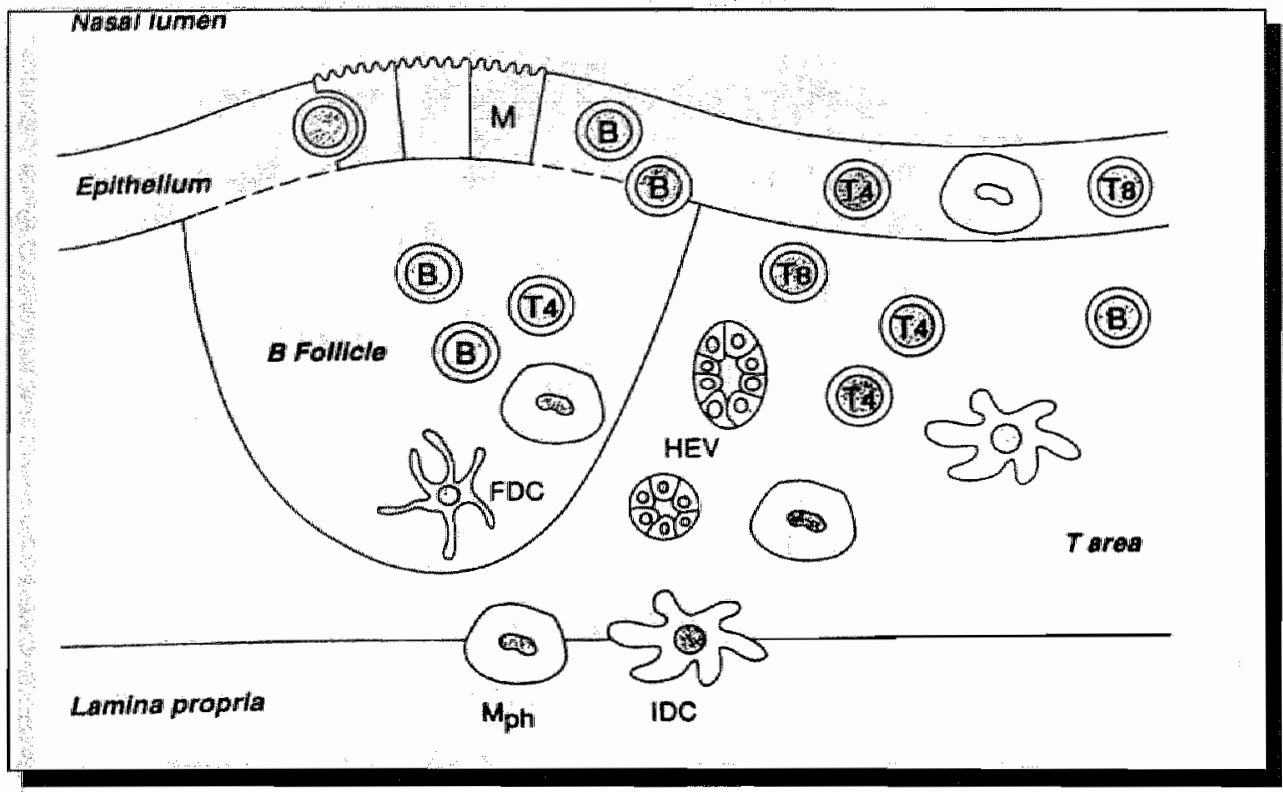

Fig.3. Schematic representation of compartments and cellular composition of NALT/WRE.

B: B cell; T4: CD4-positive T cell, T8: CD8-positive T cell, Mph: macrophages, IDC: interdigitating dendritic cell, FDC: follicular dendritic cell, HEV: high endothelial venule, M: microfold epithelial cell. (Source: Kuper CF et al. The role of nasopharyngeal lymphoid tissue. Immunol Today $1992 ; 13,6$ )

\section{Antigen uptake and drainage}

The nature of the interaction between an antigen, the nasal mucosa and NALT/WRE depends on the composition, dose and frequency of administration of the antigen and on the integrity of the epithelium. Soluble antigens may easily penetrate the whole nasal epithelium and come into contact with intra epithelial and sub mucosal leukocytes and dendritic cells. The nasal mucosa drains into the superficial cervical lymph nodes which in turn drain into the posterior cervical lymph nodes (53). However, an overload of antigen may cause antigenic material to reach the posterior cervical lymph nodes directly.

Particulate antigens may be removed quickly from the nasal mucosa by the mucocilliary system. However, when such antigens succeed in adhering to the epithelium they are taken up by specialized epithelial cells: the microfold or $\mathrm{M}$ cells, which are concentrated in the epithelium above NALT/WRE. Horseradish peroxidase gold complex particles are taken up by $M$ cells, but not by ciliated cells in the epithelium above NALT/WRE (47) (fig. 4). Uptake away from NALT/WRE has not been described, but the respiratory brush cell and the non ciliated cylindrical or cuboidal cells, which show morphological resemblance to the $M$ cells, are candidates for this role $(46,54)$. 


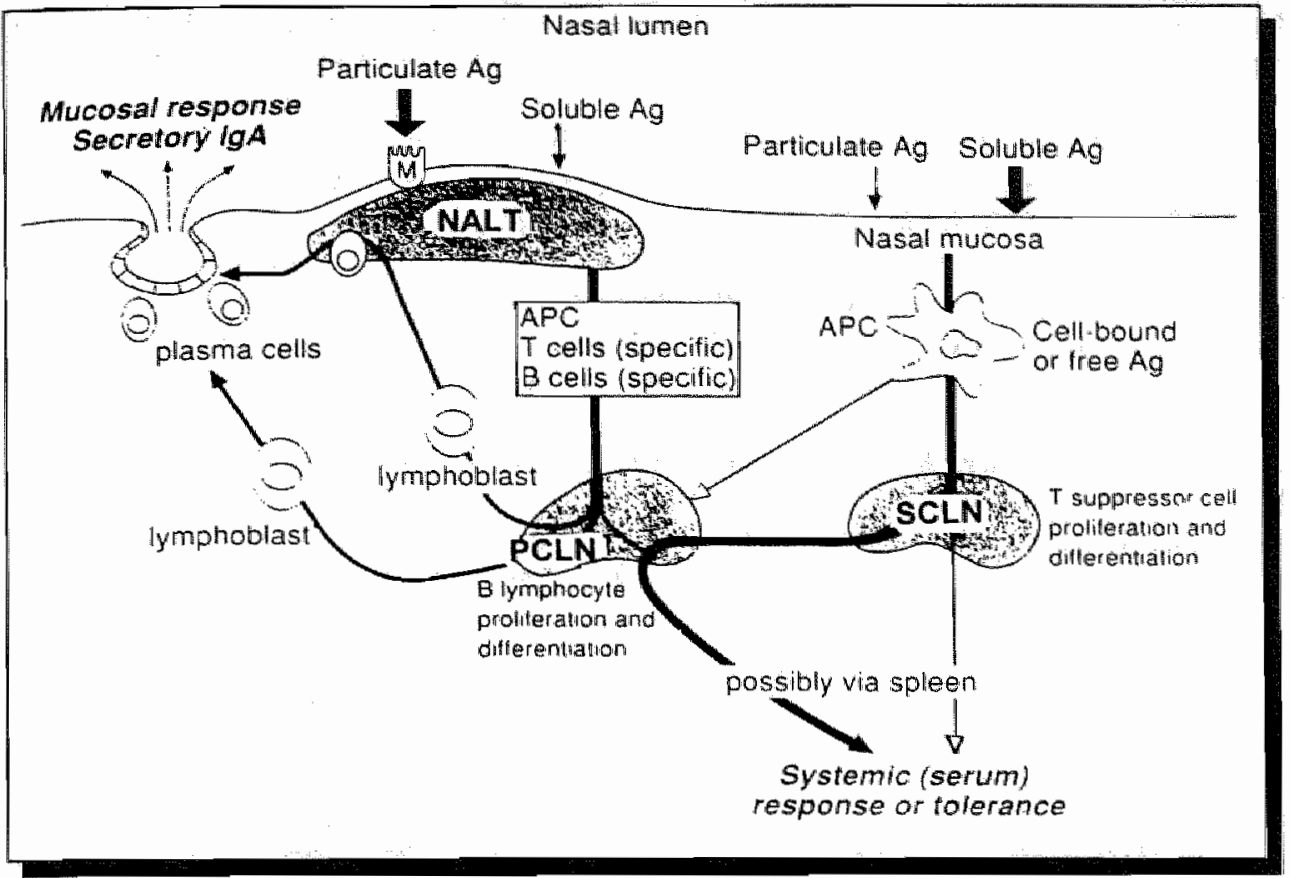

Fig. 4. A hypothetical scheme of pathways eliciting a local mucosal response and a systemic response or tolerance, via NALT/WRE and nasal mucosa (for explanation, see text).

APC: antigen presenting cell (macrophage, dendritic cell), M: microfold epitheliall cell, NALT: nose associated lymphoid tissue (see Fig. 2), PCLN: posterior cervical lymph node, SCLN: superior cervical lymph mode. (Source: Kuper CF et al. The role of nasopharyngeal lymphoid tissue. Immunol Today $1992 ; 13,6$ )

Antigen handling in the nasal mucosa, especially particulate antigen, is influenced by loss of epithelial integrity, which can be due to infection or air pollution. For instance, the adjuvant activity of cholera toxin depends on its ability to increase the permeability of the nasal epithelium to antigen $(55,56)$.

\section{Locall and systemic immune responses}

Antigenic stimulation of the mucosal immune system is known to induce specific local immune responses, notably the production of secretory immunoglobulins, and to result into specific systemic tolerance. The question is whether differences in morphology between NALT/WRE, BALT and PP are reflected in differences in responses generated in NALT/WRE in comparison to the other components of MALT.

Intra nasal inoculation of viral antigen is at least as immunogenic as oral immunization (57). 
Holt and Sedgwick (58) have studied tolerance induction to ovalbumin and shown that repeated intra nasal or inhalatory exposure results into the establishrnent of tolerance (as assessed by decreased serum titres of specific IgE and $\mathrm{g} G$ ), but intra tracheal instillation does not. These experiments show that the superficial cervical Iymph nodes into which the nasal mucosa drains are the site of suppressor $T$ cell induction and activation and may, therefore, play a pivotal role in the generation of tolerance $(59,60)$. Tolerance cannot be induced in animals up to two weeks of age (61). This might be due to a general immunological immaturity or to immaturity of component(s) of the mucosal immune system. Rats have an immature NALT/WRE up to ten days after birth (43). Therefore, a role for NALT/WRE in the processes of tolerance induction via MALT cannot be excluded.

The local reaction in NALT/WRE was examined following intra nasal application of antigen and the influence of the nature of the antigen on the response was analysed $(44,45)$. Single Intra nasal inoculation evokes almost no response, either in serum or tissues UTissues examined were lung, including BALT, NALT/WRE, posterior and superficial cervical lymph nodes, and spleen. Nasal mucosa, other than the area immediately around the NALT/WRE, was not examined). A second intra nasal inoculation with a soluble $T$ cell dependent antigen does induce a distinct response but only in the serum and in the draining posterior cervical lymph nodes. These findings confirm the importance of the posterior cervical lymph nodes in the mucosal immune system.

Most specific antibody forming cells (AFCs) in the posterior cervical lymph nodes produce $\operatorname{IgA}$. This suggests that the posterior cervical lymph nodes are involved in the generation of a secretory IgA response, possibly restricted to the nasal passages (Fig. 4). Particulate, a nonviable antigen fails to induce a significant response. The relatively low numbers of specific AFCs in the tissues and the low serum titres after Intra nasal immunization with the model antigens may be due to the limited number of exposures to the antigen.

It must, however, be kept in mind that repeated exposure via the nasal passages may lead to the induction of tolerance. The enhancement of the serum Ig levels after a second application of soluble antigen shows that memory formation accurs. Germinal centres play a major role in memory formation (62). However, only few germinal centres are observed in the NALT/WRE of Wistar rats, suggesting that NALT/WRE does not necessarily have a major role in memory formation after Intra nasal application of antigen. This function may be carried out by the efferent lymph nodes. Intra peritoneal administration of antigen has been shown to be an effective route for priming of the respiratory mucosa $(63,64)$. Therefore, the effect of lintra. peritoneal priming on the response to intra nasal challenge was compared with the effects of intra tracheal and subcutaneous priming, using a soluble, T cell dependent antigen (44). Again, significant mumbers of AFCs (IgG, IgM and IgA isotypes) were found in the posterior cervical lymph nodes after immunisation by all three routes, This emphasises the importance of these lymph nodes in the mucosal immune system. Splenic AFCs were prevalent following Intra peritoneal priming, and most of them produced $\operatorname{IgG}$ and IgM. As expected, priming by non mucosal routes induces a more systemic (serum) than mucosal response. 


\section{Current wiew on nasopharyngeal lymphoid tissue}

The information obtained from studies of NALT/WRE allows some hypotheses to be made, despite significant gaps in the understanding of antigen handling by the nasal mucosa:

1. NALT/WRE appears to be, in some respects, the principal mucosal lymphoid tissue in the respiratory tract because it develops earlier in life and has a more activated appearance in conventionally housed untreated animals than has BALT.

2. The morphological characteristics of PP and NALT/WRE indicate that PP and NALT/WRE may play equally important but different roles in the mucosal response. NALT/WRE is more a $T$ cell organ, while PP is a B cell organ. This is in accordance with data on binding of lymphocytes to HEV in PP and tonsillar tissue in man (65). The significance of the morphological differences between NALT/WRE and PP remains to be elucidated.

3. There is a separation between mucosal/secretory and systemic responses in the upper respiratory tract, similar to that found in the gut $(66,67)$.

The nature of the antigen that is exposed to the nasal mucosa and NALT/WRE and the priming routes determine the type of response (Fig. 4). Soluble antigen penetrates the whole nasal mucosal epithelium and reaches the superficial cervical lymph nodes. Therefore, these antigens preferentially induce a systemic immune response, or establish tolerance. In contrast, a particulate antigen is removed easily from the nasal mucosa but, on repeated exposure or when the ciliary apparatus is affected (both conditions are met by viable, replicating pathogens), it is taken by M cells and reaches NALT/WRE.

Via the posterior cervical lymph nodes a predominant slgA response is evoked and secretory immunity is established. The balance between activation in the posterior and superficial nodes determines the eventual response. Although a pivotal role for NALT/WRE in the establishment of a secretory response is suggested, it must be kept in mind that NALT/WRE is probably also involved in the systemic response. The studies on the immunological effects of tonsillectomy and adenoidectomy are in support of this and some of these studies evidently show that this clinical intervention at early age may not be as harmless as is often thought $(19,20,32,72)$.

What happens to NALT/WRE upon antigen exposure is still unknown and it is obwious that for answering this question the development of an adequate animal model is required. In this study a modell of WR in the rat is described in which specific immunological features of the oro nasopharyngeal lymphoid tissue are investigated. 


\section{References}

1. Grundfast KM. Adenotonsillar hypertrophy and upper airway obstruction in evolutionary perspective Laryngoscope $1982 ; 92: 650-656$.

2. Talaat AM, Nahhas MM. Cardiopulmonary changes secondary to Chronic adenotonsillitis. Arch Otolaryngol 1983; 109: 30-33.

3. Behlfett $\mathrm{K}$, Linder-Aronson S, Neander P. Posture of the head, the hyoid bone, and the tongue in children with and without enlarged tonsils. Eur J Othod 1990; 12:458-467.

4. vain Someren VH, Hibbert J, Stothers JK, Kyme MC, Morrison GAJ. Identification of hypoxemia in children having tonsillectomy and adenoidectomy. Clin Otolaryngol 1990; 15 : 263-271.

5. Waldeyer HWG. (1884), cited by Olah, I. In Tonsils. Structure, Immunology and Biochemistry (Antoni F and Staub M, eds) Akademia Kiado 1978; 5049.

6. Brandtzaeg $\mathbb{P}$. In Immunology of the Lung and Upper Respiratory Tract (Bienenstock J. ed.) McGraw-Hill 1984; 28-95.

7. Plum $J$, van Cauwenberge $P_{n}$ de Smedt M. Phenotyping of mononuclear cells from tonsils and corresponding biopsies using a cytofluorometer. Acta Otolaryingol (Stockh) 1986; 101: 129-134.

8. Skoog T. To the Question of the Physiological significance of the Tonsils; an animal experimental study. Acta Otolaryngol 1935; XXIII: 63-84.

9. Tabata T, Katsurahara T, Enomoto T, Kitashoji N and Tanaka S. Immunological function of human tonsil. Acta Otolaryngol 1975; 80: 474-478.

10. Korsrud FR, Brandtzaeg P. Immune system of human nasopharyngeal and pallatine tonsil: histomorphometry of lymphoid components and quantification of immunoglobulin-producing cells in health and disease. Clin Exp Inmunol 1980; 39:361-370.

11. Brandtzaeg P. Immune functions and immunopathology of palatine and nasopharyngeal tonsils. In Immunology of the Ear (Bemstein J, Ogra P eds.) Raven Press, New York, 1987.

12. Brandtzaeg P, Halstensen TS. Immunology and immunopathology of tonsils. Adv Oto Rhino Laryngol 1992; 47: 64-75.

13. Tang $X$, Hori S, Osamura RY, Tsutsumi $Y$. Reticular crypt epithelium and intra-epithelial lymphoid cells in the hyperplastic tonsil: a histochemical analysis. Pathol Int 1995; 45: 34 44. 
14. van Nieuwkerk EBJ, de Wolf CJM, Kamperdijk EWA, van der Baan $S_{*}$ Lynphoid and non lymphoid cells in the adenoids of children with otitis media with effusion: a comparative study. Clin Exp Immunol 1990; 79: 233-239.

15. Brandtzaeg $\mathbb{P}$. The immune system of the nose and nasopharynx. In Allergic and vasomotor rhinitis: patho physiological aspects. (Mygind N, Pipkorn U eds.) Munksgaard, Copenhangen 1987.

16. Hameleers DMH, Stoop AE, van der Ven 1, Biewenga J, van der Baan S, Sminia T. Intra epithelial lymphocytes and non lymphoid cells in the human nasal mucosa. Int Arch Allergy Appl Immunol 1989; 88: 317-322.

17. Quiding-Jarbrink $M$, Granstrom G, Nordstrom I, Holmgren $\mathbf{J}$, Czerkinsky $C$. Induction of compartmentalized B-cell responses in human tonsils. Infect lmmunol 1995; 63: 853-857.

18. Donovan R, and Soothill JF. Immunological studies in children undergoing tonsillectomy. Clin Exp Immunol 1973; 14: 347-357.

19. D'Amelio R, Palmisano L, Le Moli S, Seminara $R$, Aiuti F. Serum and Salivery IgA lewels in normal subjects: Comparison between Tonsillectomized and non-tonsillectomized Subjects. Int Anch Allergy Immunol 1982; 68: 256-259.

20. Cantani A, Bellioni P, Salvinelli F, Businco L. Serum Immunoglobulins and secretory IgA deficiency in tonsillectomized children. Ann Allergy 1986; 57 .

21. Sainz M, Gutierrez F, Moreno PM, Munoz C, Ciges M. Changes in immunologic response in tonsillectomized children. Clin Otolaryngol 1992;17:376-379.

22. Katic V, Klapan I, Katic $M$ et al. Acute upper respiratory tract infections and indications for tonsillectomy in children. Int J Ped Otorhinolaryngol 1994; 29: 169-178.

23. Smith RS, Sherman NA, Newcomb RW. Synthesis and Secretion of Immunoglobulin, Including IgA, by Human Tonsil and Adenoid Tissue Cultured in vitro. Int Arch Allergy 1974; 46: 785-801.

24. Tamura $S$, Masuda $Y$, Inokuchi 1 , Terasawa $K$, Sugiyama $\mathbb{N}$. Effect of and Indication for Tonsillectomy in IgA Nephropathy. Acta Otolaryngol (Stockh) 1.993; Suppl 508: 23-28.

25. Iino Y, Ambe K, et al. Chronic Tonsillitis and IgA Nephropathy. Acta Otolaryngol (Stockh) 1993; Suppl 508: 29-35.

26. Sugiyama $N$, Shimizu J, et al. Clinicopathological Study of the Effectiveness of Tonsillectomy in IgA Nephropathy Accompanied by Chronic Tonsillitis. Acta Otolaryngol (Stockh) 1993; Suppl 508: 43-48.

27. Bicknell PhG. Role of adenotonsillectomy in the management of pediatric ear, nose and throat infections. Ped Inf Dis J, 1994; 12: 75-78. 
28. Ostergaard PA. Tonsillar IgE plasma cells predict atopic disease. Clin Exp Immunol 1982; 49: $163-166$.

29. Yadaw RS, Yaday SPS et al. Serum immunoglobulin E levels in children with chronic tonsillitis. Int J Ped Otorhinolaryngol, 1992;24: 131-134.

30. Griffin JL, Ramadan HH, Adham RE. Prevalence of IgE-Mediated Hypersensitivity in Children With Adenotonsillar Disease. Arch Otolaryngol Head Neck Sur 1994; 120.

31. Maldyk E, Abgarowicz T, et al. Palatine tonsils and rheumatoid arthritis. Rheumatol 1969; T. VII 2.

32. Vianna NJ, Greenwald $P$, and Davies NP. Hypothesis: Tonsillectomy and Hodgkin's Disease: The lymphoid Tissue barrier. Lancet 1971; ii: 431-432.

33. Gledovic $Z$ and Radovanovic $Z$. History of tonsillectomy and appendectomy in Hodgkin's disease. Eur J Epidemiol 1991; 612-615.

34. Read R. and Read C. Breathing can be hazardous to your health. New Sci 1991; 23:34-36.

35. Loo SK. and Chin KN. Lymphoid tissue in the nasal mucosa of primates, with particular reference to intra epithelial lymphocytes. I Anat 1974; 117: 249-259.

36. Harkema JR, Plopper $\mathrm{CG}$, Hyde DM, al: Nonolfactory surface epithelium on the nasalcavity of the Bonnet Monkey: a morphologic and morphometric study of transitional and respiratory epithelium. Am I Anat 1987; 180: 266-279.

37. Mair TS, Batten EH, Stokes CR, Bourne FJ. The histological features of the immune system of the equine respiratory tract. J Comp Pathol 1987; 97: 575-586.

38. Mair TS, Batten EH, Stokes CR, Bourne FJ. The distribution of mucasal tymphoid nodules in the equine respiratory tract. J Comp Pathol 1988; 99: 159-168.

39. Shuh J, Oliphant O, Doige C. Abstract. Allergologie 1989; 7, 310.

40. Kelemen $\mathrm{G}$. The junction of the nasal cavity and the pharyngeal tube in the rat. Arch of Otolaryngol $1945 ; 24: 143-153$.

41. Belal AA, El-Gohery $Y$, Talaat M. Nasal and paranasal pathology in experimental billharziasis. J Laryngol Otol 1977; 91: 391-400.

42. Ichimiya $\mathbb{I}$, Kawauchi $H$, Tanaka $T$, Fujiyoshi $T$. and Mogi $G$. Distribution of immunocompetent cells in normal nasal mucosa: comparisons among germ-free, specific pathogen-free, and conventional mice. Ann Otol Rhinol Laryngol 1991; 100: 638-642.

43. Hameleers DMH, van der Ende M, Biewenga J, Sminia T. An immunohistochemical study on the postnatal development of the rat nasal-associated lymphoid tissue (NALT). Cell Tissue Res 1989; 256; 431-438. 
44. Hameleers $\mathrm{DMH}_{\text {g }}$ van der Ven I, Sminia T, Biewenga I. Anti-TNP forming Cells in Rats after different routes of priming with TNP-LPS followed by intranasal Boosting with the same antigen. Res Immunol 1990; $141: 515-528$.

45. Hameleers DMH, van der Ven I, Biewenga J, Sminia T. Mucosal and systemic antibody formation in the rat after intranasal administration of three different antigens. Immunol Cell Biol 1991; 69: 119-125.

46. Spit BJ, Hendriksen EGJ, Bruijntjes JP, Kuper CF. Nasall lymphoid tissue in the rat. Cell Tissue Res 1989; 255: 193-198.

47. Kuper CF, Spit BJ, Bruijntjes JP, Hendriksen EGJ, Hameleers DMH. In Nasal Carcinogenesis in Rodents: Relevance to Human Health Risk (Feron VI. and Bosland $M C_{\text {, }}$ eds) $1989 ; 30-36$, Pudoc.

48. de Jong FICRS, van Breda Vriesman PJC, Vlek LFM. Basic mechanisms of the nasopharyngeal immune-system. Clin Otolaryngol 1985; 10:228.

49. Kuper CF, Hameleers DMH, Bruijntjes JP. et al. Lymphoid and non-lymphoid cells in nasalassociated lymphoid tissue (NALT) in the rat. An immuno-and enzyme-histochemical study. Cell Tissue Res 1990; 259: 371-377.

50. van der Ven I, Sminia T. The development and structure of mouse nasal-associated Lymphoid Tissue: An Immuno- and Enzyme-Histochemical Study. Reg Immunol 1993; 5: 69-75.

51. Plesch BEC. Histology and immunohistochemistry of bronchus associated lymphoid tissue (BALT) in the rat. Adv Exp Med Biol. 1982; 149: 491-497.

52. Butcher EC, Rouse RV, Coffman RL, et al. Surface phenotype of Peyer's patch germinal centre cells: implications for the role of germinal centres in $B$ cell differentiation. I Immunol 1982; 129: 2698-2707.

53. Tilney NL. Patterns of lymphatic drainage in the adult laboratory rat. J Anat $1971 ; 109: 369$ 383.

54. Richardson J, Bouchard T, Ferguson CC. Uptake and transport of exogenous proteins by respiratory epithelium. Lab Invest $1976 ; 35: 307-312$.

55. Tamura S, Samegai Y, Kurata T. Effects of cholera toxin on delayed-type hypersensitivity to sheep red blood cells inoculated intra nasally into mice. Microbiol Jmmunol 1988; 32: 1.145 1161.

56. Lycke N, Karlsson U, Sjolander A, Magnusson KE. The adjuvant action of Cholera Toxin is associated with an increased intestinal permeability for luminal antigens. Scand J Immunol $1991 ; 33: 691-698$. 
57. Vanoff $B$, Andre $C$, Fontagnes $R$, Jourdan $G$. Secondary immune response to oral and nasal rough mutant strains of Salmonella typhimurium. Ann lmmunol Inst Pasteur 1982; $133 \mathrm{D}$ : $61 \% 70$.

58. Holt $\mathrm{PG}$ and Sedgwick JD. Suppression of IgE responses following inhalation of antigen. A natural homeostatic mechanism which limits sensitization to aeroallergens. Immunol Today $1987 ; 8: 14-15$.

59. Sedgwick JD. and Holt PG. Induction of IgE-secreting cells and IgE isotype-specific suppressor $\mathbb{T}$ cells in the respiratory lymph nodes of rats in response to antigen inhalation. Cell Immunol 1985; 94: 182-194.

60. Wan Wilsem EJG, Breve J, Savelkoul $\mathrm{H}$, et al. Oral Tolerance is Determined at the Level of Draining Lymph Nodes. Immunobiol 1995; 194: $403-414$.

61. Holt $\mathrm{PG}_{2}$ Vines $\mathrm{J}$, Britten D. Suppression of $\mathrm{IgE}$ responses by antigen inhalation: failure of tolerance mechanism(s) in newborn rats. Immunology 1988; 63: 591-593.

62. Kraal $G$, Weissman IL, Butcher EC. Germinal centre cells: antigen specificity, heavy chain class expression and evidence of memory. Adv Exp Med Biol 1985; 186: 145-151.

63. Scicchitano R, Husband AJ, Clancy RL. Contribution of Intra peritoneal immunization to the local immune response in the respiratory tract of sheep. Immunology 1984; 53: 375-384.

64. Sheldrake RF. Specific antibody response in porcine respiratory tract secretion following Intra peritoneal immunization. Vet Immunol Immunopathol 1989; 21: 177-186.

65. Pals ST, Kraal $G$, Horst $\mathbb{E}$, et al. Human lumphocyte - high endothelial venule interaction: organ- selective binding of $\mathrm{T}$ and $\mathrm{B}$ lymphocyte populations to high endothelium. $J$ Immunol $1986 ; 137: 760-763$.

66. Jeurissen $S H M$, Claassen $E$, van Roojen $N$, Kraal $G$. Intra-intestinal priming leads to antigen-specific IgA memory cells in peripheral lymphoid organs. Immunology 1985; 56 : 417.423.

67. Russell MW, Mestecky J. Induction of the mucosal immune response. Rev Infect Dis 1988; 10 Suppl 2: $440-446$.

68. Jeurissen SHM, Dijkstra CD. Characteristics and functional aspects of non-lymphoid cells in rat germinal centres, recognized by two monoclonal antibodies ED5 and ED6. Eur I Immunal 1986; 16:562-568.

69. Sminia T, van der Brugge-Gamelkoorn GJ, Jeurissen SHM. Structure and function of bronchus associated lymphoid tissue (BALT). Crit Rev Immunol 1989;9:119-150.

70. Sminia T, Plesch BEC. An immunohistochemical study of cells with surface and cytoplasmic immunoglobulins in situ in Peyer's patches and lamina propria of rat small intestine. Virchows Arch 1982; (Cell Pathol) 40: 181-189. 
71. Sminia T, Janse EM, Plesch BEC. Ontogeny of Peyer"s patches of the rat. Anat Rec 1983; 07: 309-316.

72. Yoshida $\mathrm{Y}$,Yamauchi. S, Myaka $\mathrm{H}$, Okamoto $\mathrm{K}$, Ozawa A. Tonsillectomy and autoantibodies in patients witl habituel tonsillitis. Auris Nasus Larynx 1980; 7: 151-157. 


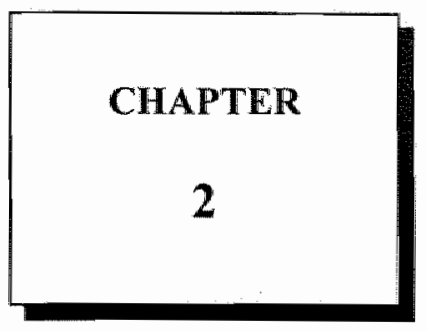

ANATOMY AND SURGICAL APPROACH OF THE WALDEYER RING EQUIVALENT IN THE RAT 


\section{Introduction}

Exposure of a human organism to inhalation antigens and alimentary antigens at the level of the oro-nasopharynx may lead to inflammatory reactions, to induction of immune responses in lymphoid tissues located in this area $(1,2,3,4,5,6)$ and/or it may lead to induction of tolerance (7).

Human lymphoid tissues in the oro-nasopharynx are known as Waldeyer's ring (W/R) and can be considered to be the body's first line of defence against antigens. The WR (8) is composed of the pharyngeal tonsil (also called adenoid), the palatine tonsils, the lingual tonsil, lymphoid tissue at the entrance of the Eustachian tube and scattered lymphoid tissue in the submucosa of the posterior pharyngeal wall (9).

In man, the local and systemic immunological function of WR is not completely understood. Infections and allergic reactions in the oro- nasopharynx are common. Upper airway problems affect individuals of all ages, notably children. Diseased human lymphoid tissue from the oronasopharynx can be easily obtained by surgical removal of the tonsils. Tonsillectomy is still a routine procedure. Diseased adenotonsillar tissues have been extensively studied histologically, immunohistochemically $(10,11,12,13)$ and phenotypically in terms of lymphoid subsets (14). If one wishes to study non diseased WR tissue and its function, an animal model is required. Obviously healthy human tonsils are not available for this purpose.

With the intention of developing such an experimental model, we carried out a careful search in the rat for an equivalent of the human WR.

The first description of accumulations of lymphoid cells in juxtaposition to the respiratory pharynx in rats was given by Keleman in 1945 (15). Studies performed by De Jong et al. (16) revealed that these accumulations of lymphoid cells have a defined location close to the first nasal choana.

To enable performing experiments in wivo a surgical technique, which would allow access to these lymphoid organs in a living rat, was considered essential. Since no such technique was described, we developed a surgical transpalatinal approach for in wivo experiments and for harvesting the minute organs in 1oto. Prior to the development of the surgical technique we had to determine the exact location of the organs.

In this chapter we present the methods by which we ascertained the exact position of the NALT/WRE and the result of this work. Consequently we report on the light and electron microscopical appearance and present data showing their participation in antigen transport and showing their involution upon ageing in the rat, as in man. Then we describe their vascularisation, \#ymphatic drainage and conclude with the description of the surgical approach to these organs. 


\section{Material and methods}

\section{Animatlls}

Inbred male Lewis rats, eight to twenty-four weeks old, barrier raised and conventionally maintained, were obtained from the Department of Animal Service of the University Maastricht.

\section{Anaesthesia}

General anaesthesia was induced by administering either:

- Hyphorm ${ }^{\mathrm{R}} 0.05 \mathrm{ml} / \mathrm{gram}$ body weight s.c., followed by Sedamun $\mathrm{R}^{\mathrm{R}} 0.01 \mathrm{ml} / \mathrm{gram}$ body weight im.

or

- inhalation of ether.

Animals were euthanised according to the Dutch law on experimental animal procedures.

\section{Corrosion of rat heads}

The rat head was dissected from the body at the level of C2-C3. The skin was removed from the head. The head was placed in a $200-\mathrm{ml}$ beaker filled with water. A biologic detergent, containing proteolytic enzymes, was added. Under continuous stirring the solution was heated for sixty minutes, twenty minutes at $30^{\circ} \mathrm{C}$, twenty minutes at $60^{\circ} \mathrm{C}$ and twenty minutes at $90^{\circ} \mathrm{C}$. The remaining soft tissue was gently removed from the skeleton by forceps. The clean skull was cut sagitally into a left and a right half. The saw cut was made slightly lateral to the midline, sparing: the nasal septum on one half of the skull.

\section{Decalcification of rat heads}

Decalcification was performed in a mixture of equal parts of $(8 \mathrm{~N})$ formic acid and ( $1 \mathrm{~N})$ sodium formate for three weeks. After rinsing in tap water (24 hours) the specimens were dehydrated in graded alcohols and embedded in paraplast. Serial $10 \mu \mathrm{m}$ sections were stained with hematoxylin and cosin (17). Sections were screened light microscopically in order to identify lymphoid structures:

\section{Immunohistology}

A two-step immunoperoxidase technique was used for immunostaining of Jymphoid tissue sections as described in Chapter 3.

\section{Scanning electron microscopy}

Entire lymphoid organs were removed and fixed in $2.5 \%$ glutaraldehyde in $0.1 \mathrm{M}$ sodium phosphate buffer ( $\mathrm{pH}: 7.2$ ), dehydrated in graded ethanol series and critical pount dried with liquid $\mathrm{CO}_{2}$. Next the specimens were attached to aluminum stubs with silver adhesive, coated with gold palladium and observed in a Cambridge SE 180 Scanning Electron Microscope operated at 15 KV. 


\section{Transmission Electron Microscopy}

Lymphoid tissue was removed and fixed for at least two hours in $2.5 \%$ glutaraldehyde in $0.1 \mathrm{M}$ sodium phosphate buffer ( $\mathrm{pH}: 7.24^{\circ} \mathrm{C}$ ), postfixed in $1 \%$ osminmtetroxide in $0.1 \mathrm{M}$ phosphate buffer ( $\mathrm{pH}: 7.2$ for 60 minutes at room temperature), dehydrated and embedded in Epon 812 . Ultra thin (70-80 nm) sections were cut on a Reichert ultra microtome, and collected on Formvar coated copper grids. Sections were contrasted with saturated uranyl acetate in $50 \%$ ethanol for ten minutes and 10\% lead citrate for five minutes. Transmission, electron microscopy was performed using a Philips CM 10.

\section{Vascularisation}

The blood supply of the Waldeyer ring equivalent (WRE) was studied using two techniques: injection with Indian ink (Pelikan Ink, Gunther Wagner, Germany) in six rats and silicon casting technique in 10 rats.

The Indian ink method was performed as follows; after ether anaesthesia the abdomen was opened and perfusion with $60 \mathrm{ml}$ of physiologic saline at room temperature was performed with the tip of the cannula residing in the first $10 \mathrm{~mm}$ of the aortic arch ( $\mathrm{n}=3$ ) or the tip of the cannula residing in the abdominal aorta $(n=3)$. The perfusion was followed by injection of approximately $20 \mathrm{ml}$ of Indian ink.

The Technovite casting technique was performed according to the following procedure; Technovit 7001 (methylmetacrylate), obtained from KHinipath B. V, the Netherlands was used, 100 grams of Technovit $7001,1 \%$ hardener $(1)$ and $1 \%$ cadmium red were mixed and subsequently stirred for five minutes at $4^{\circ} \mathrm{C}$. Subsequently, $1 \%$ of hardener (2) was added and mixed thoroughly. After euthanasia of the animals the abdomen of the rat was opened and the abdominal aorta and inferior vena cava were identified and cannulated. Next retrograde perfusion of the abdominal aorta was carried out with saline by slight manual pressure and approximately $20 \mathrm{ml}$ of Technovit mixture was infused into the aorta subsequently. After perfusion, the bodies were kept overnight under water at $4^{\circ} \mathrm{C}$ for the Technovit to solidify.

\section{Lymph drainage}

For studying the lymph drainage of the Waldeyer ring equivalent, toluidin blue $(n=10)$ or Indian Ink (Pelikan Ink, Gunther Wagner, Germany) $(n=10)$ was injected into the frontall part of this organ after prior dissection of the local mucosa by means of a $10 \mu$ Hamilton syringe. Euthanisation and dissection of the rat head and neck were performed under a stereo microscope (OpMi 6, Zeiss, Germany) after respectively 30 minutes, $1,2,3$ and 4 hours ( $n=2$ for each time interval). 


\section{Results}

\section{Topographical anatomy}

Anatomy is studied by observation of freshly dissected and corroded rat skulls (fig 1,2$)$. The roof of the nasal cavity is formed by the nasal bones, the ethmoid bone and the sphenoid bone rostrally and by the frontal bone dorsally. The lateral walls of the nasal cavity are formed by the incisival bone rostrally and by the frontal bone and maxilla enclosing the ethmoid dorsally. The floor of the nasal cavity (fig 2,3 ) is formed by the hard palate. The hard palate consists of a rostral, an intermediate and a dorsal part. The rostral part is formed by the palatine processes of both the incisival bone and the maxilla. The intermediate part of the hard palate is formed by an osseous lamella forming the bridge between the two first choanas. The dorsal part of the hard palate is formed by the horizontal part of the palatinal bone and the laterally attached alveolar process of the maxilla. The nasal cavity is separated into a right and a left half by the nasal septum. The nasopharyngeal duct lies in a direct line with the nasal septum (fig.1).

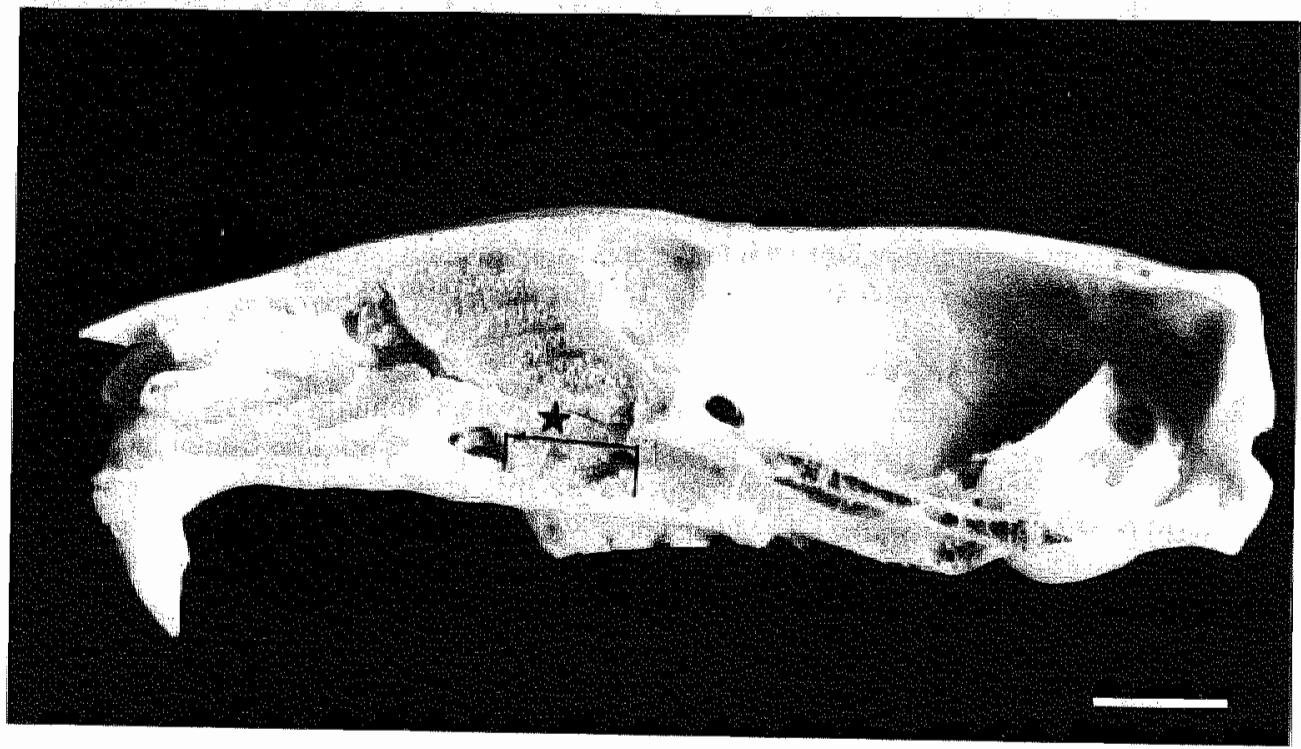

Fig. 1. Medial aspect of the right half skull of a Lewis rat. Asterisks mark the lacation of the NALT/WRE in the nasopharyngeal duct. The NALT/WRE is absent in this corroded skull. Bar represents $0.5 \mathrm{~cm}$. 


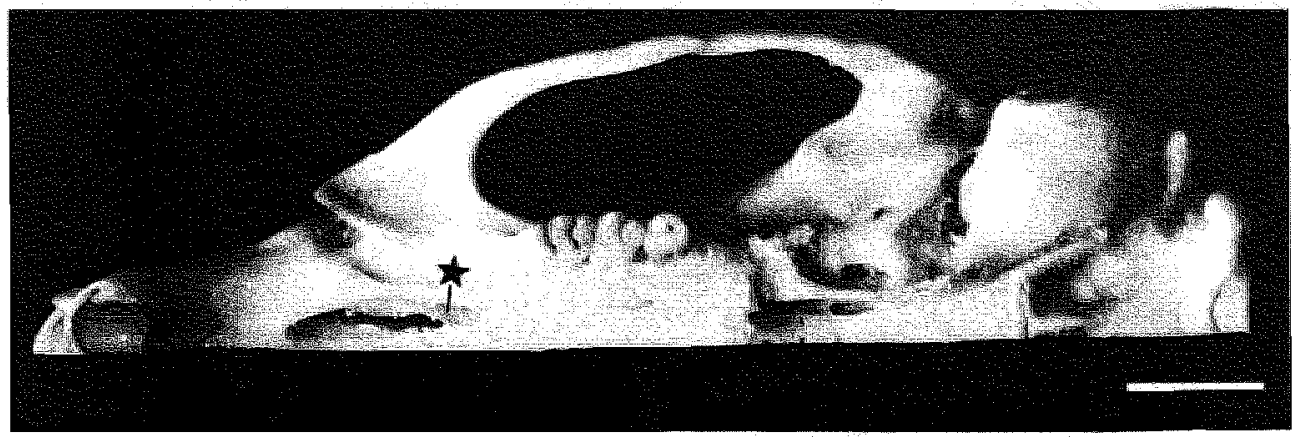

Fig. 2. Oral view of the left half skull of the Lewis rat. Asrerisks mark the location where the rostral part of the NALT/WRE is visible in the dorsolateral side of the first choana. The NALT/WRE is absent in this corroded skull. Bar represents $0.5 \mathrm{~cm}$.
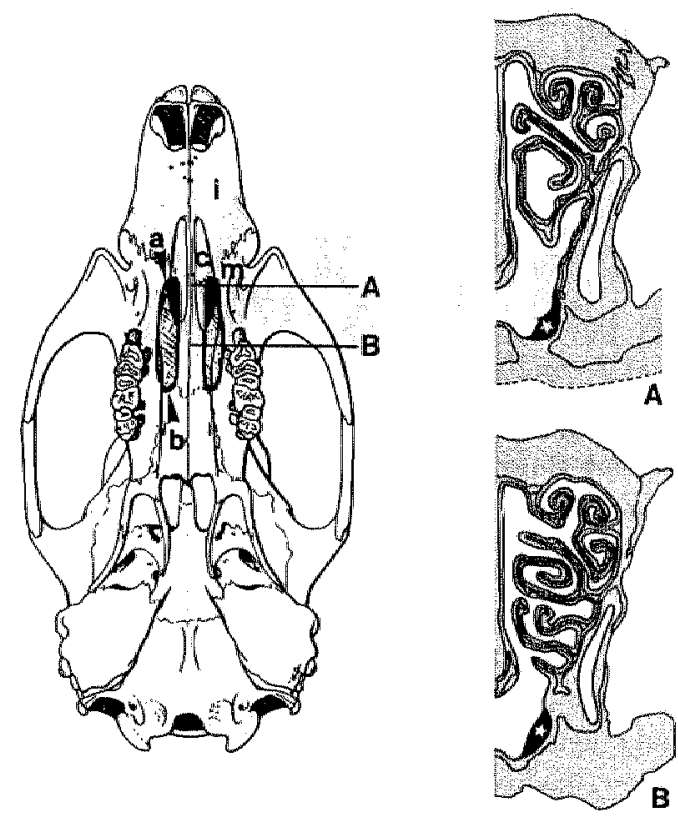

Fig. 3. In addition to the rostrall part of the NALT/WRE (see arrow head a), shown in fig. 2 the dorsal part of the NALT/WRE residing nasally to the hard palate is also marked (see arrow head b). i: incisival bone, $m$ : maxillar bone, $c$ : first choana. A and $B$ represent two coronal sections of the left side of the skull at the indicated location showing the position of the NALT/WRE close to the palate. Asterisk indicates the NALT/WRE. (With permission from H. Rensema, Department of Anatomy and Embryollogy, University Maastricht). 
Coronal sections of a decalcified rat skull shows that the NALT/WRE is located in the lateral wall of the nasopharyngeal duct where it appears rostrally at the level of the palatine fissure and ends dorsally at the level of the second molar (fig 3 ). It is covered by the epithelial lining of the nesopharyngeal duct (fig 4 ).

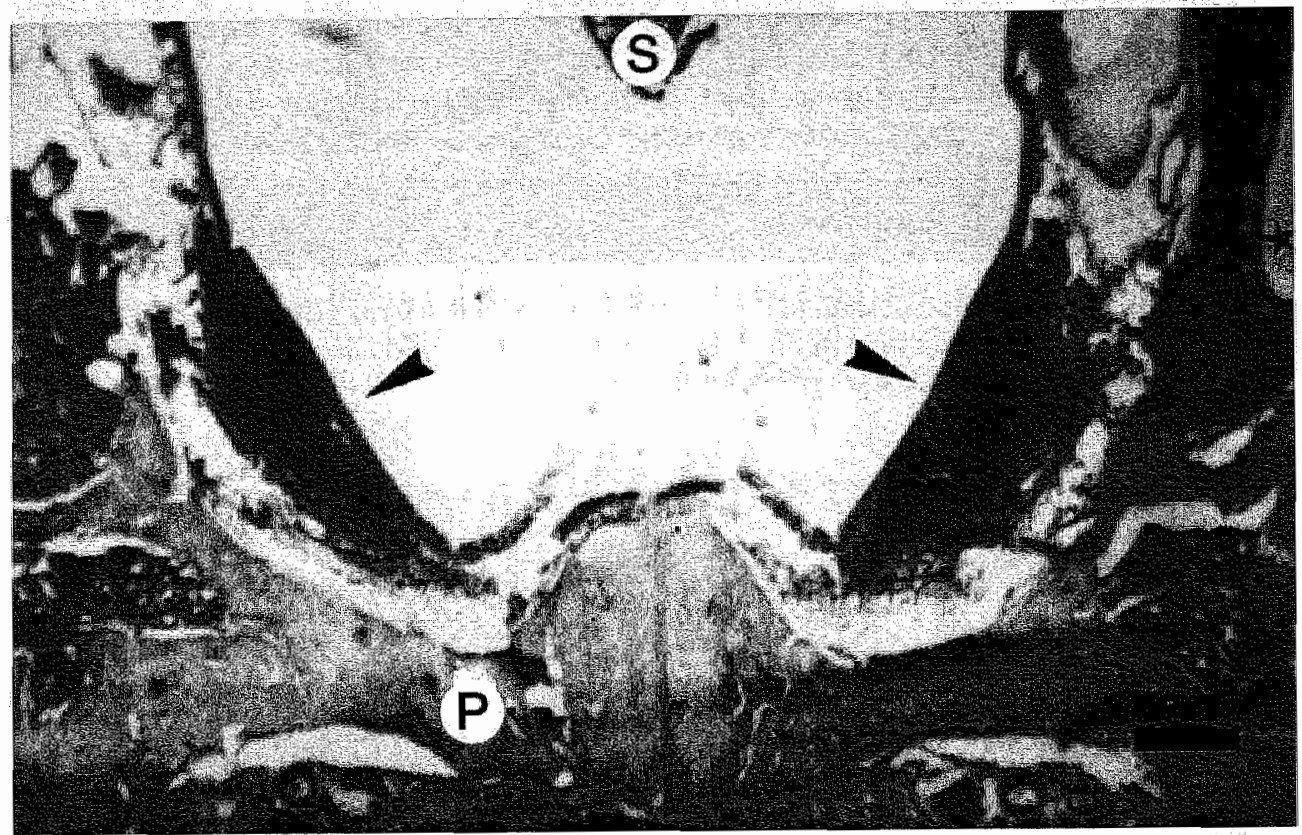

Fig. 4. HE stained coronal section of a decalcified rat skull. Arrow heads undicate the two lymphoid organs residing underneath the mucosal lining of the nasal cavity. $\mathrm{p}$ : hard palate, $s$ : masal septum. Asterisk indicates the maxillary sinus. Bar represents $1 \mathrm{~mm}$.

\section{Light and electron microscopy}

Light and electron micrographs of the lymphoid organs show at the luminal aspect dome shaped protrusions into the nasal cavity (fig.5).

The epithelial lining of the NALT/WRE consists of a great number of ciliated epithelial cells, a few mucous goblet cells and microvilli bearing cells (M cells). The epithelium is continuous through the few superficial crypts (fig.6). M cells, speciallised for antigen transport, are present both solitarily and in clusters (fig. 7,8). Transmission electron micrographs reveal $M$ cells with. a slightly more electron opaque cytoplasm compared to the ciliary cells. The nucleus of these non ciliated cells was usually located at the base of the cell. Many mitochondria and a few electron dense granules of various sizes as well as rough endoplasmic reticulum were seen through the entire cytoplasm, whereas vesicles and vacuoles were mainly situated at the apical side of the cell. The vesicles and vacuoles in the electron dense cytoplasm of $M$ cells were greater in number and size than those in the electron lucent cytoplasm of the ciliated cells (fig.9). 
Underneath this epithelium there is an accumulation of lymphoid cells. These lymplaid cells are organised in lymph follicles and interfollicular areas. Lymph follicles contaim mainly B cells and the interfollicular areas contain mainly $T$ cells and high endothelial venules. No interlymphoid septa were seen. At the base of the lymphoid follicles the lymphoid cells tend to be more loosely arranged. In between these cells there is an increase of collagen fibres and nerves. Arterioles and vessels are occasionally seen.

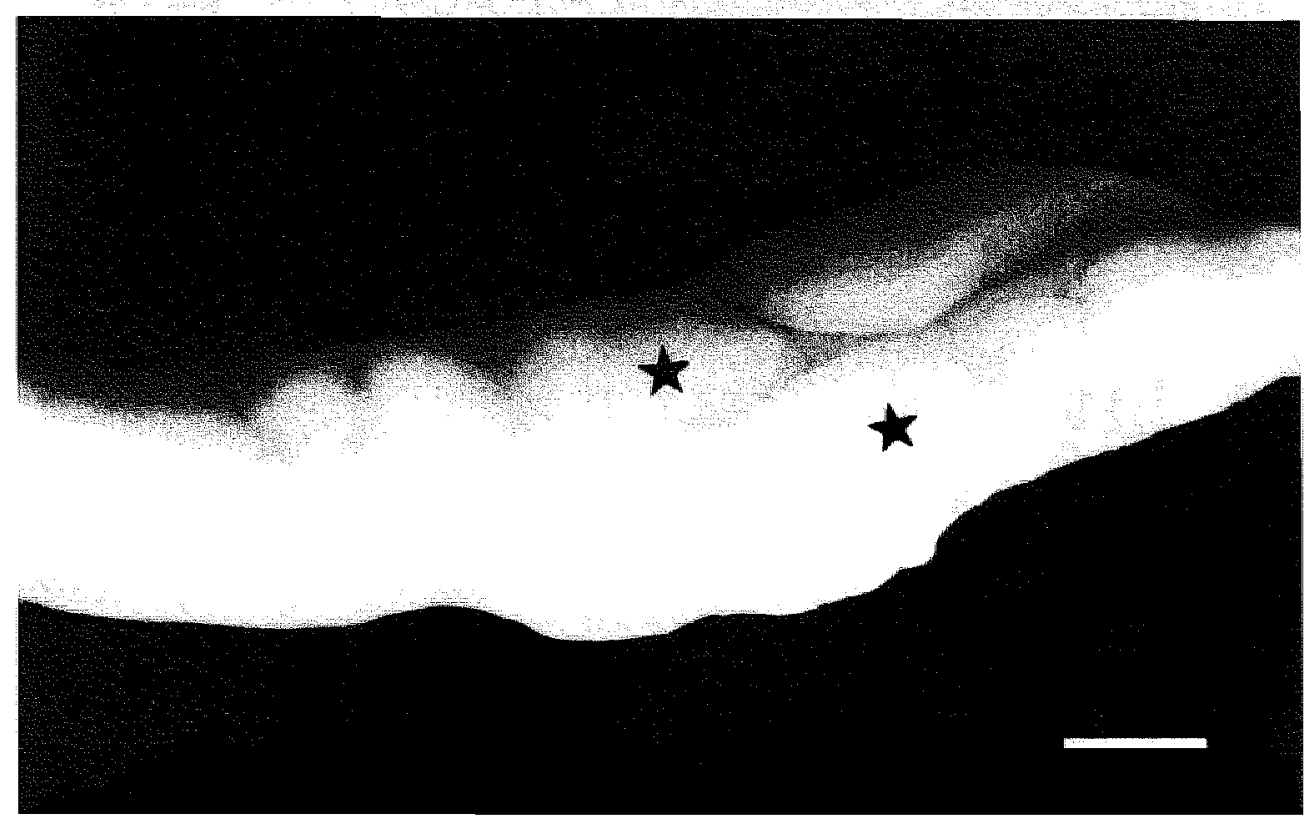

Fig.5. Nasal aspect of the NALT/WRE showing the dome shaped (asterisks) areas bulging into the nasal cavity. Light microscopical photograph (Tessovar, Zeiss, Germany). Bar represents $0.5 \mathrm{~mm}$. 


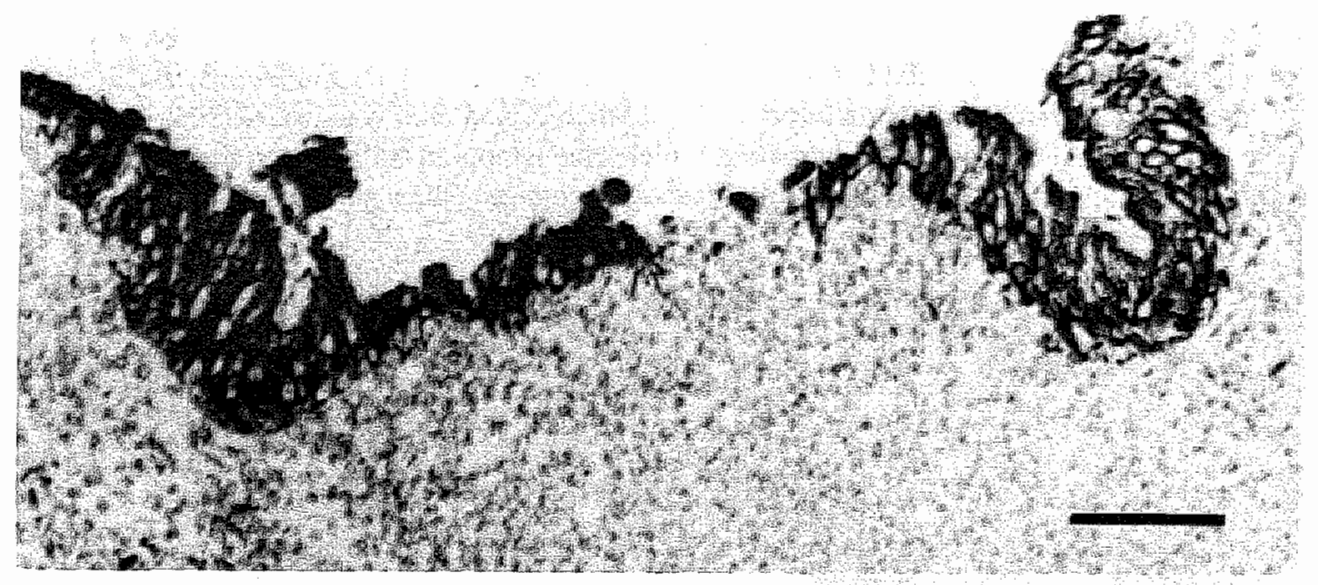

Fig. 6. Anti-keratin staining of a $4 \mu \mathrm{m}$ section of the NALT/WRE. A detail of the epithelial lining at the luminal side of the NALT/WRE in which the epithelial cells are visible (arrow). Bar represents $0,33 \mathrm{~mm}$. 


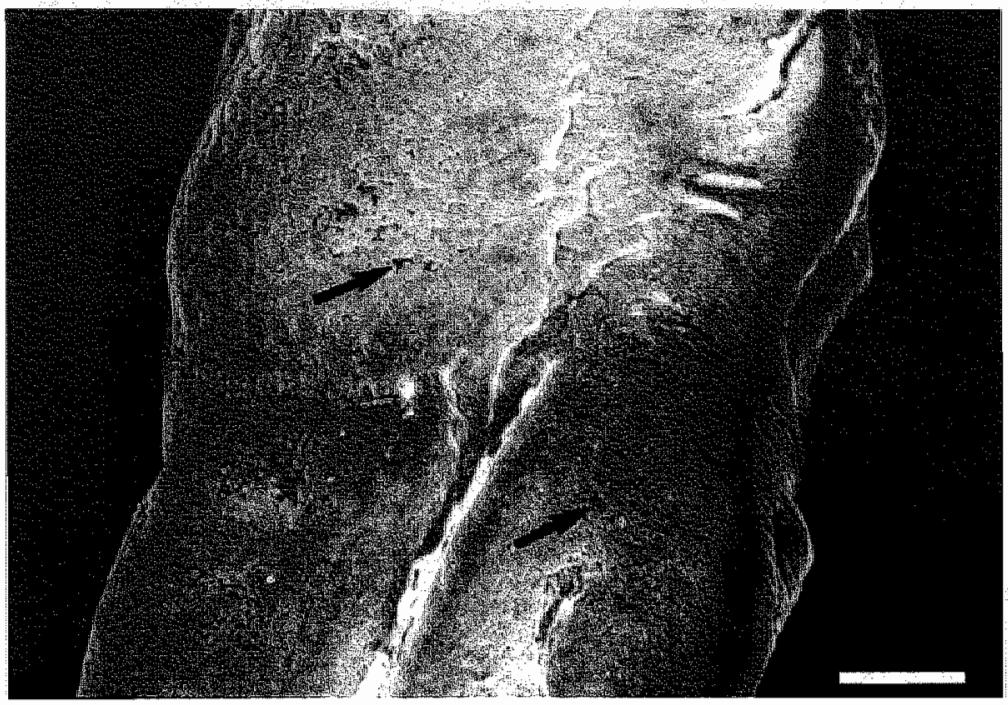

Fig. 7. Scanning micrograph of the luminal aspect of the NALT/WRE showing multiple small indentations (arrows). Bar represents $120 \mu \mathrm{m}$.

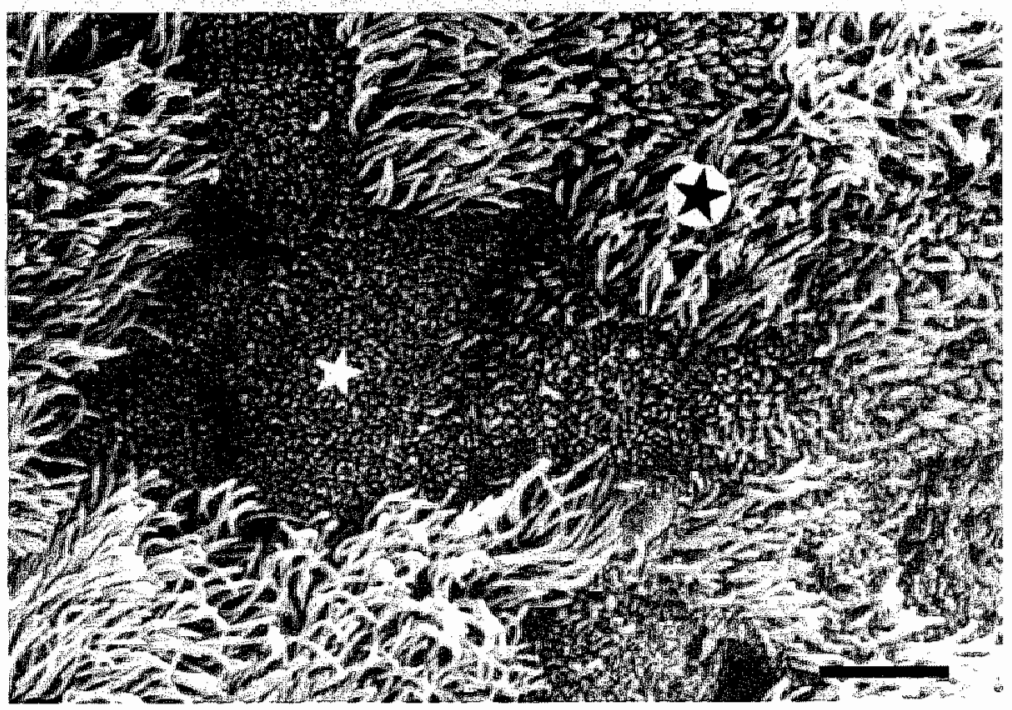

Fig.8. A detail of fig.14. At a higher magnification these indentations (white asterisk) turn out to be areas with $M$ cells that are clearly distinct from surrounding ciliated epithelial cells (black asteriski). Bar represents $3.5 \mu \mathrm{m}$. 


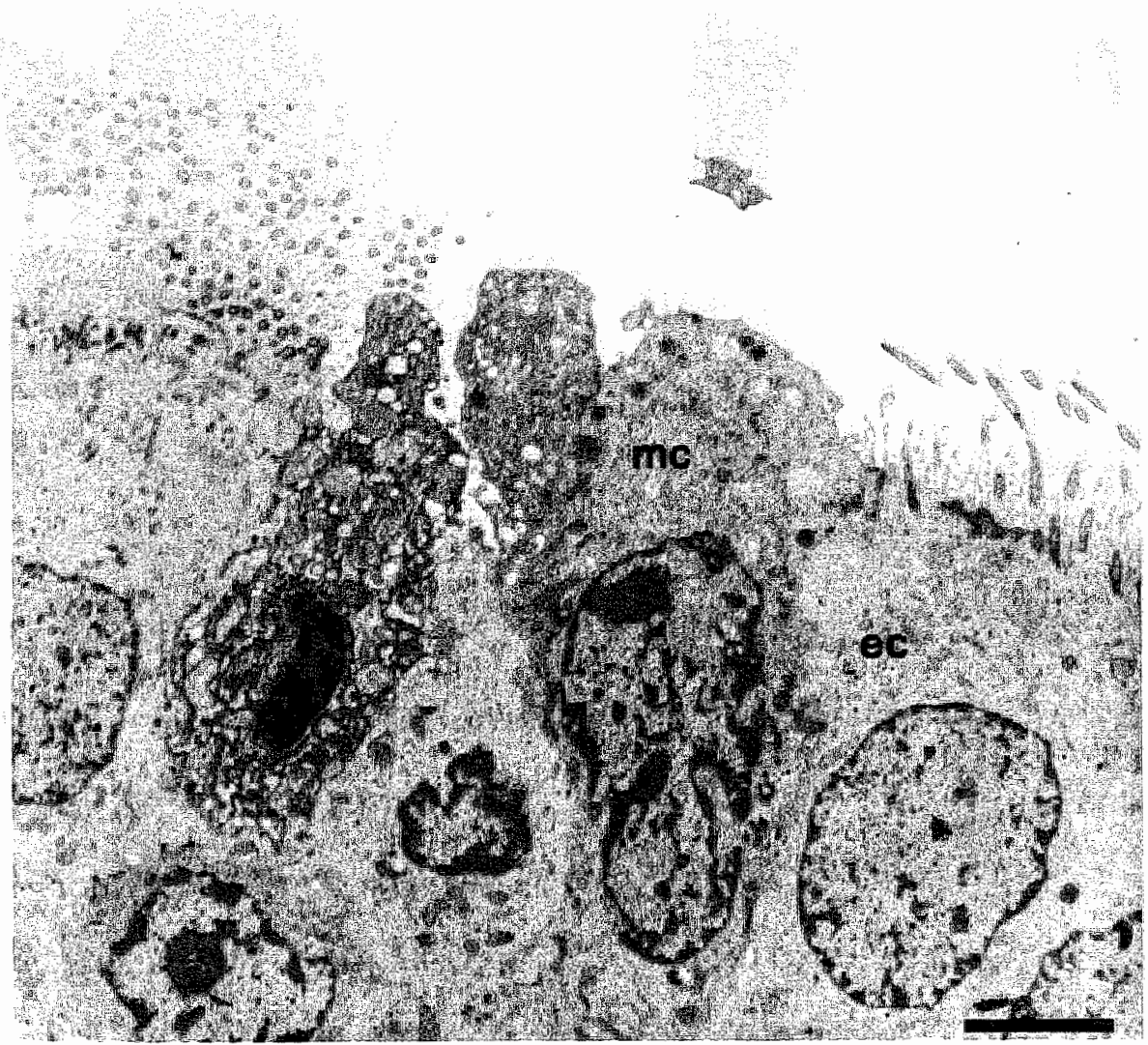

Fig. 9. Transmission micrograph of the NALT/WRE showing microvilli bearing cells (mc). These cells have an electron dense cytoplasm and the nucleus at the basal part of the cell. Mitochondria and dense granules are present throughout the cytoplasm whereas vesicles and vacuoles in various sizes are located in the apical part of the cell. Note the difference in ultra structure between $M$ cells (mc) and ciliary epithelial cells (ec). Bar represents $3 \mu \mathrm{mn}$.

\section{Involution upon ageing}

In order to determine whether the nomal pattern of growth and development of the nasopharyngeal duct rat tonsillar tissue resembles that of the human pharyngeal and palatine tonsils, all of the removed rat lymphoid tissue was weighed. Our data show that rapid growth of the NALT/WRE takes place during the first eight weeks of life, followed by a gradual growth till the age of eleven weeks (young adult age). The organs decline in weight after eleven weeks. The total body weight increases until the twenty-third week, whereas the organ weight of liver and spleen increases rapidly during the first eleven weeks. After the eleventh week the liver increases in weight whereas the weight of the spleen tends to stabilise (fig.10). 

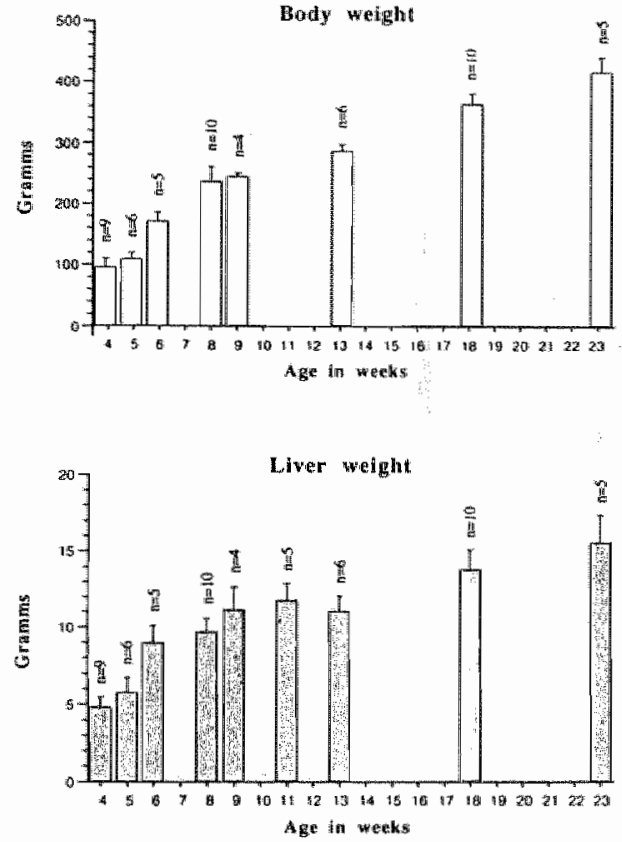
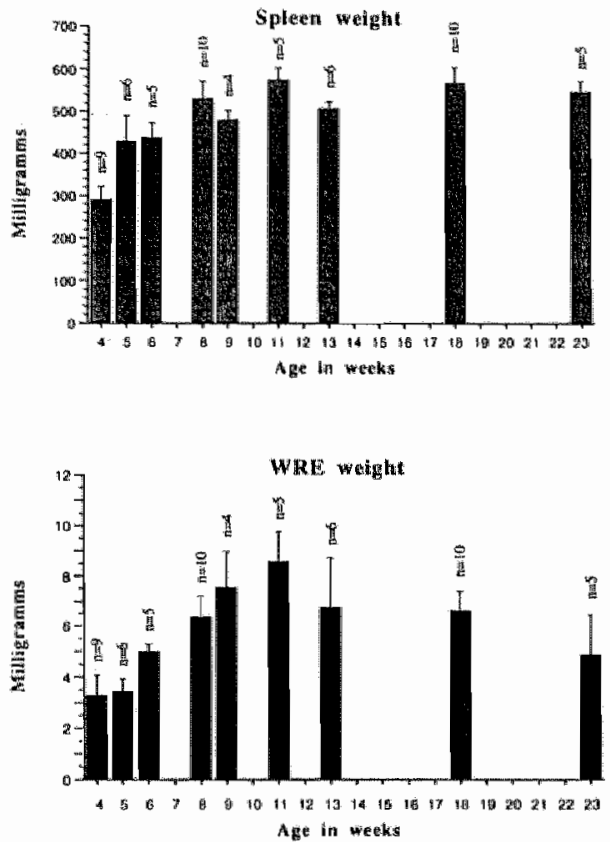

Fig. 10. Diagrams showing total body weight $( \pm \mathrm{SD})$ and weight of the liver, spleen and the NALT/WRE ( \pm SD) from 4 until 24 weeks, $n=4-10$ (no results for total body weight at eleven weeks). Total body weight and weight of the organs increase rapidly during the first eleven weeks. After the $11^{\text {th }}$ week the liver increases in weight whereas the spleen tends to stabilise. NALT/WRE tisstue declines after the $11^{\text {th }}$ week. 
Blood supply and lymphatic drainage

Careful preparation of Indian ink or Technovite 7001 injected blood vessels shows that the NALT/WRE receives its arterial blood from the sphenopalatine artery (fig. 11).

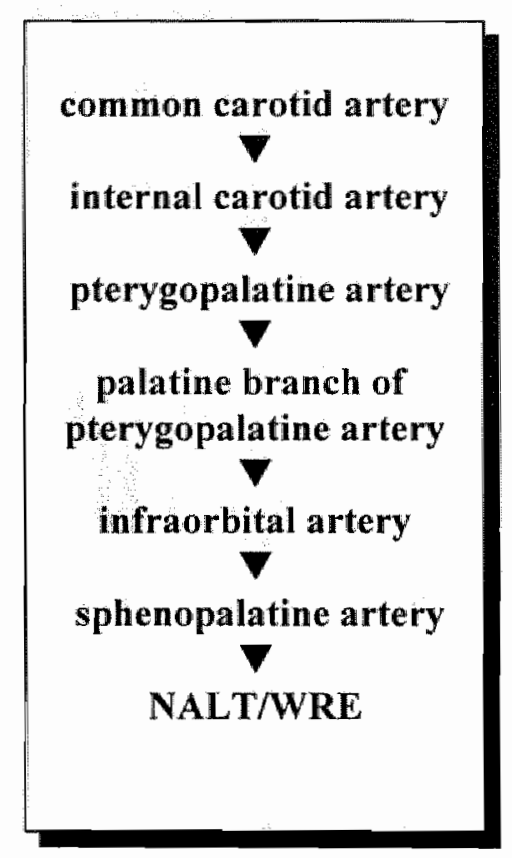

Fig. II. Schematic presentation of successive branches of carotid artery involved in arterial blood supply to the NALT/WRE.

To visualise the lymphatic drainage of the NALT/WRE toluidine blue or Indian ink was injected into the NALT/WRE. Approximately one hour after injection of the stain a colouring of the deep cervical lymph nodes was observed. With this technique no staining was seen in the superficial lymph nodes from the moment of injection till five hours after injection. 


\section{Surgical transpalatinal approach}

Based upon experience gathered while studying the anatomic localisation we developed the transpalatinal surgical approach for in vivo experiments and for harvesting the lymphoid organs in toto.

The anaesthetized rat is positioned on its back in anti-Trendelenburg position with its nose towards the surgeon. The body is immobilised by mild traction on the front limbs. The limbs are fixed to the operating table with two rubber bands. The mouth is opened and fixed in this position by two rubber bands, connected to the upper and lower incisives respectively. The procedure is performed under a stereo microscope (OpMi 6, Zeiss, Germany). A U-shape incision is made into the mucosa of the hard palate just medial to the incisiva and molars as indicated in fig. 12. This results in a mucosal flap that is undermined and folded towards the pharynx, thus exposing the hard palate (fig. 13). Bleeding is controlled by bipolar coagulation forceps (Entermed, the Netherlands). To open the hard palate and, if required, to remove the palatine process a slightly curved, sharp pointed, scissor (Entermed, the Netherlands) is used. At this stage of the procedure both lymphoid organs are fully visible in the nasopharyngeal duct and accessible for experiments. In order to remove the organs all bony fragments have to be extracted first to prevent tissue damage during further dissection (fig. 14). Each lymphoid organ is carefully removed by simultaneous cutting and gentle pulling (fig. 15), using a fine-tipped forceps (Entermed, the Netherlands) and a curved dissecting scissor (Oswald Leibinger, Mublheim-Stetten, Germany). The removed lymphoid organs are placed on a warm saline moistened gauze. The lymphoid organs are rod shaped, about $7 \mathrm{~mm}$ long, $1 \mathrm{~mm}$ in diameter. Their weight is approximately $4 \mathrm{mg}$ (fig. 16). 


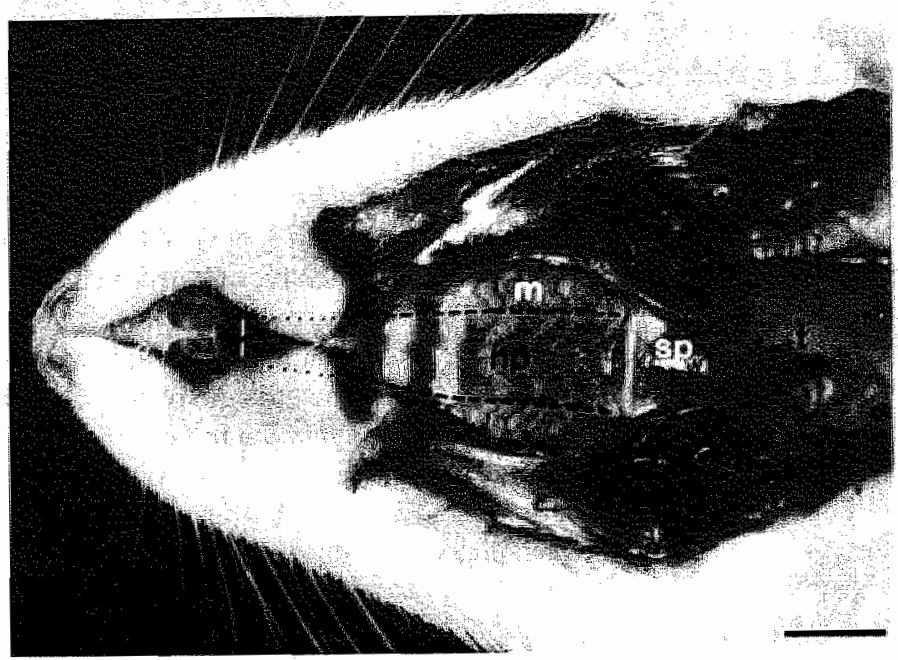

Fig. 12. Oral view on the mucosal lining of the palate. The $U$-shape incision (dotted line) is drawn on the photograph of the mucosa.

$\mathrm{m}$ : molar, hp: hard palate sp: soft palate, t: tongue. Bar represents $0.5 \mathrm{~cm}$.

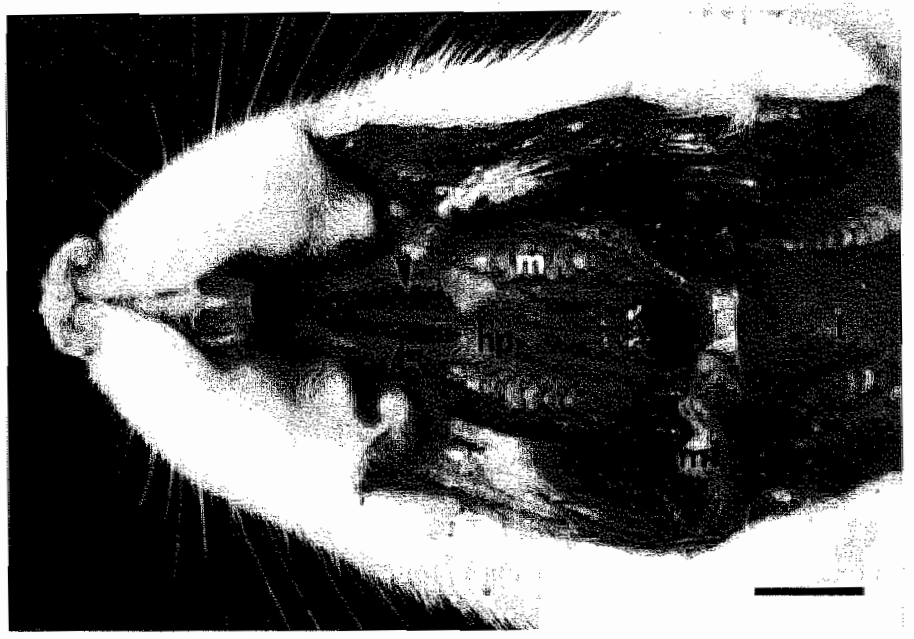

Fig. 13. Oral view on the bony palate. The mucosa has been removed completely which allows insight into the first choana. Parts of the lymphoid organs are visible at the dorsolateral side of the first choana. hp: hard palate, m: molar, $\mathrm{mf}$ : mucosal flap t: tongue. Bar represents $0.5 \mathrm{~cm}$. 


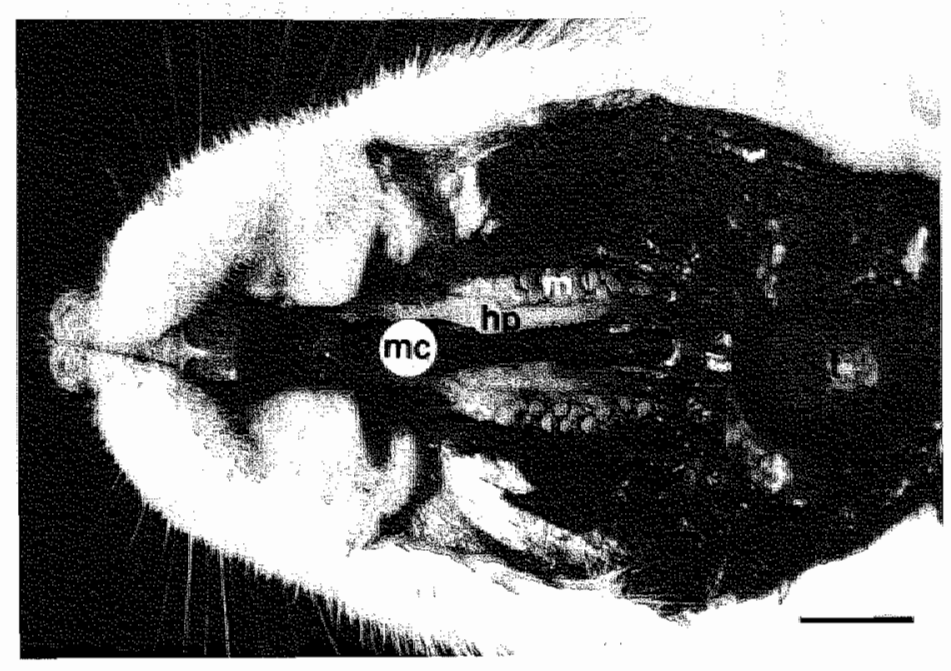

Fig. 14. Oral view on the almost completely removed hard palate, allowing a look into the nasal cavity and at the two lymphoid organs (arrow heads).

hp: hard pallate remnant, $m$ : molar, nc: nasal cavity, $t$ : tongue. Bar represents $0.5 \mathrm{~cm}$.

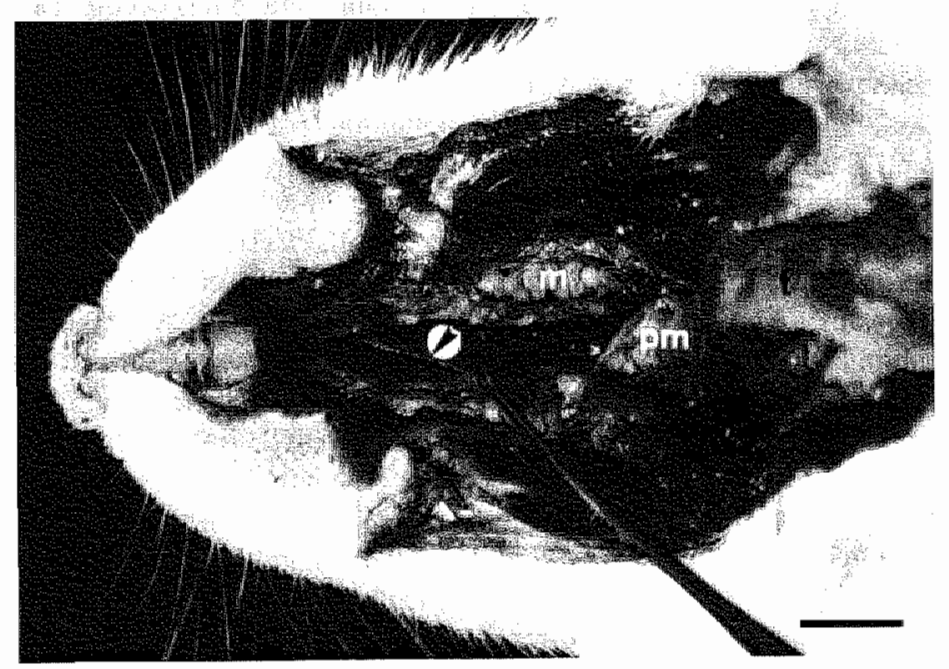

Fig. 15. Oral view into the nasal cavity. The left lymphoid organ is pulled out of its niche towards the opposite sidle (arrow head).

m: molar, pm: part of palatal mucosal lining, t: tonguc. Bar represents $0.5 \mathrm{~cm}$. 


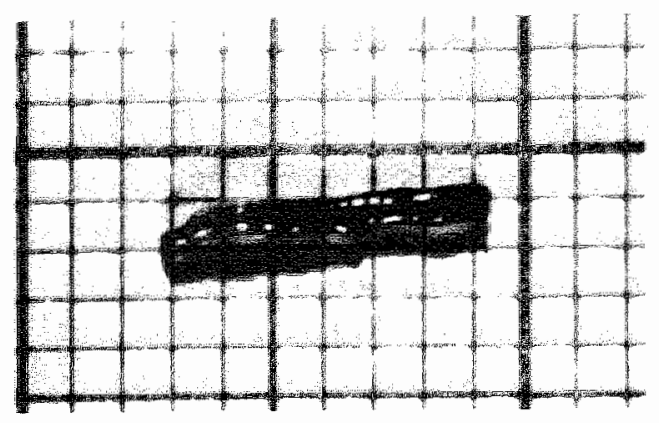

Fig. 16. Rod shaped lymphoid organ (NALT/WRE) on graph paper.

\section{Discussion}

In order to develop an immunologically well defined animall model for the human ring of Waldeyer we examined the rat for lymphoid tissue in the oro nasopharynx.

Studies from Keleman (15), De Jong et al.(16), Spit et al. (27) and Koornstra et al. (19) have revealed two lymphoepithelial organs residing at both lateral walls of the nasopharyngeal duct and a few (unorganised) lymphoid cells around the nasolacrimal ducts. In order to use them for various experiments we needed to gain access to these lymphoid organs. The technique of sagitally sectioning of the decalcified rat skulls did not allow us to obtain the organs in toto. Hameleers et al. (18) described a technique for obtaining them in one piece by using sagital splitting of the rat skull. This method however, can only be applied in sacrificed animals.

Our first goal was to develop a surgical technique to gain access to the lymphoid organs to perform experiments in vivo and to obtain them in toto. By employing this technique we succeeded in manipulating the lymphoid organs while the animals were kept alive. This technique has the advantages of in situ exposing the lymphoid organs in living animals, allowing these organs to be manipulated. Thus we were able to perform short term functional studies. Lymphoid tissue, thus obtained, was described in terms of its location, light and electron microscopic appearance, relation with supplying blood vessels and relation with draining lymph vessels.

If one compares the anatomical position of human tonsillar tissue organised in Waldeyer's ring to the position of the nose associated lymphoid tissue (NALT/WRE) in rats, the latter appears to be organised differently; not in a ring like structure but in well defined, rod shaped organs restricted to the nasopharyngeal duct, occupying a constant location.

With respect to the vascularisation there is a marked difference in origin of blood supply between the rat NALT/WRE and the human WR tissues. The intemal carotid artery supplies the rat NALT/WRE whereas it is the external carotid artery that supplies both the human pharyngeal and the palatine tonsils (9). 
Neither the rat NALT/WRE, nor the human pharyngeal and palatine tonsils have afferent lymphatic vessels. The efferent lymphatic vessels from the NALT/WRE in the rat were found to drain preferentially into the deep cervical nodes, and to a lesser extent into the superficial nodes (19). This is similar to the human situation where efferent lymphatics from the pharyngeal and palatine tonsils drain into the superior deep cervicall and jugular lymph nodes (20).

Light and ultramicroscopic studies demonstrated that the lymphoid organs residing in the nasopharyngeal duct are lined with pseudo stratified ciliated epithelium. This epithelium is also found in the nasopharyngeal duct and the meatus region (21). It is continuous through the few superficial crypts. In this epithelium a few goblet cells, demonstrating the secretory capacity of this epithelium were seen. Presence of solitary and clustered M cells indicate antigen transport. $\mathrm{M}$ cells are in contact with both luminal antigens and intra epithelial and sub epithelial lymphocytes and macrophages $(22,23,24,25)$. They are uniquely specialised to transport antigen macromolecules (26). The epithelium was shown to be infiltrated by lymphocytes. These data in the Lewis rat are in accordance to the data obtained in the Wistar rat by Spit et al.(27) and show that just like the human WR the NALT/WRE is a part of the mucosa associated lymphoid tissue (MALT).

Human diseased adenoid tissue shows a considerable variation in size (28). Subtelny (29) found that adenoid tissue grows rapidly during the first three years of life. It contimues to grow slowly till the age of ten to fifteen years when it reaches its greatest size. After this peak in tissue growth it declines until it is usually atrophied at adulthood (30). Human diseased tonsillar tissue also varies widely in size in relation to age, body height and body weight. In contrast to adenoid tissue, however, there is a tendency for palatine tonsils of patients less than seven years ofd to be smaller in size than the palatine tonsils of older patients $(31,32)$. A significant decrease in palatine tonsillar tissue mass with increasing age could not be shown.

The growth pattern of the NALT/WRE shows a rapid increase in organ weight in the young Lewis xat with a maximum organ weight at eleven weeks of age and a decline in organ weight at the age of twelve weeks and older. No signs of involution were

noticed. This corresponds to the palatine tonsils in man. These findings show that in terns of inwolution upon ageing the rat NALT/WRE resemble the palatine tonsils of man rather than the pharyngeal tonsils which shows a involution upon ageing although persistent nasopharyngeal lymphoid tissue in adults is described (33).

On account of the histology, lymph drainage and involution upon ageing the NAL,T/WRE of the rat resembles the pharyngeal tonsil and to a lesser extent the palatine tonsils in man. Therefore from this point onwards in the text, we will continue to use the term Waldeyer's ring equivalent (WRE) when referring to these organs.

We conclude that this distinct WRE tissue may offer a suitable animal model for studying the immunological role of thuman Waldeyer's ring. 


\section{References}

1. Morag $A$, Ogra PL. Immunologic aspects of tonsils. Anm Otol Rhinol Laryngol. 1975; Suppl 19, 84: 37.42 .

2. Ogra PL. Effect of tonsillectomy and adenoidectomy on nasopharyngeal antibody response to polio virus. N Eng J Med 1971, 284:59-61.

3. Scadding KS. Immunology of the tonsils: a teview. J Ray Soc Med. 1990; 83: 104-107.

4. Brandtzaeg. P. Immune functions of human nasal mucosa and tonsils in health and disease: in Bienenstock J (ed): Immunology of the Lung and Upper Respiratory Tract. New York, McGrawHill, 1984; 28-95.

5. Brandtzaeg P, Halstensen TS. Immunology and Immunopathology of tonsils. Galioto GB (ed): Tonisils: A Clinically Oriented Update. Adv Otorhinolaryngol. Basel, Karger. 1992; 47, 64-75.

6. Surjan L, Surjan M. Immunologic role of human tonsils. Acta Otolaryngol. 1971; 71:190-193.

7. Kuper CF, Koornstra PJ, Hameleers DMH, Biewenga $J$, Spit BJ, Duijwestijn AD, van BredaVriesman PJC, Sminia T. The role of nasopharyngeal lymphoid tissue. Immunol Today $1992 ; 13$, 6: $219-224$

8. Waldeyer HWG. (1884), cited by Olah 1 in The structure of Tonsills. In : Antoni F, Staub M, eds. Tonsils. Structure, immunology and biochemistry. Budapest: Akadem ia Kiado 1978; 5-49.

9. Faustino R, Suarez MD. The elinical anatomy of the tonsillar (Waldeyer's ring). Ear Nose Throat J. $1980 ; 59: 447-453$.

10. Korsud FR, Brandzaeg P. Immune system of human nasopharyngeal and palatine tonsils: Histomorphometry of lymphoid components and qualification of immuno globulin-producing cells in health and disease. Clin Exp Immunol. 1980; $39: 361-370$.

11. Bachert C, Moller P. Die Tonsille als MALT (mucosa-associated lymphoïd tissue) der Masenselleimhaut. Laryngol Rhinol Otol. 1990; 69: 515-520.

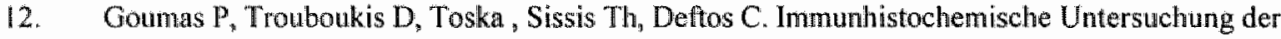
Gaumentonsillen. Laryngol Rhinol Otol. 1988; 67:34-37.

13. Matthews JB, Manish KB. Oral Tonsils: An Immunoperoxidase Study. Int Arch Allergy Appl Immunol. 1982; 69: 21-25.

14. Plum J, van Cauwenberge $P$, de Smedt $M$. Phenotyping of mononuclear cells from tonsils and corresponding biopsies using a cytoflucrometer. Acta Otolaryngol (Stockh) 1986; 101: 129-134.

15. Kelemen $G$. The junction of the nasal cavity and the pharyngeal tube in the rat. Arch of Otolaryngol 1945; 24: 143-153. 
16. de Jong FICRS, van Breda Vriesman PJC, Vlek LFM. Basic mechamisnns of the nasopharyngeal immune-system. Clin Otolayngol 1985; 10:228.

17. Grote JJ. The autonomic innervation of the nasal mucosa. Thesis University Nijmegen 1974; 12.

18. Hameleers DMH. Immunology of the upper respiratory tract: studies on rat nasal-associated lymphoid tissue (NALT) and human nasal mucosa. Thesis 1990;30-32.

19. Koornstra PJ, de Jong FICRS, Vlek LFM, Marres EHMA, van Breda Vriesman JC. The Waldeyer ring Equivalent in the Rat. A Model for Analysis of Oronasopharyngeall Immune Responses. Acta Otolaryngol (Stockh) 1991; 111: $591-599$.

20. Brodsky L. Tonsillitis, Tonsillectomy and adenoidectomy. In Head and Neck Surg Otolaryngol. Bailey B. ed. Lippincott Company, Philladelphia 1993; 1: 835.

21. Liebich HG. Zum bau der oberen Luftwegwe der weissen Ratte (Mus rattus norvegicus, var. albinos). Anat Anz 1975; $138: 170-179$.

22. Trier JS. Structure and function of intestinal $M$ cells. Gasteroenterology Clinics of North America $1991 ; 20: 3$.

23. Schmedtje JF. Some histochemical characteristics of lymphoepithelial cells of the rabbit appendix [abstract]. Anat Rec 1965; 151: 412 .

24. Schmedtje JF. Fine structure of intercellular lymphocyte clusters in the rabbit appendix epithelium [abstract]. Anat rec 1966; 151: 417.

25. Owen RL, Jones AL. Epithellal cell specialization within human Peyer's patches: An ultrastructural study of intestinal lymphoid follicles. Gasteroenterol 1974; 66: 189-203

26. Olah $\mathrm{I}$, Surjan $\mathrm{L} \mathrm{J}_{\mathrm{r}}$, Toro I. Electron microscopic observations on the antigen reception in the tonsillar tissue. Acta Acad Sci Biol Hung 1972; 23:61-73.

27. Spit BJ, Hendriksen EGJ, Bruijntjes JP, Kuper CF. Nasal lymphoid tissue in the rat. Cell Tissue Res 1989; 255: 193-198.

28. Pruzansky S. Roentgenencephalometric studies of tonsills and adenoids in normal and pathologic states Ann Otol Rhinol Laryngol 1975; Suppl 19, 84: 55-62.

29. Subtelny ID. The significance of adenoid tissue in orthodontia. Angle Ortod 1954; 24: 59-69.

30. Handelman CS, Osborne G. Growth of the nasopharynx and adenoid development from one to eighteen years. Angle Ortod 1976; 46:243-259.

31. Crombie IK, Barr G. An investigation into factors that may influence tonsil morphology. J Roy Soc Med 1990; 83: 20-21. 


\section{Chapter 2}

32. Stearns $M$. The relationship of adenoid weight to tonsillar weight. J Laryngol Otol 1983; 97: 519 521.

33. Hollender AR, Szanto PB. Lymphoid hyperplasia in the nasopharynx; a study of 131 autopsy specimens. Arch Otolaryngoll 1945; 41: 291-294. 


\section{CHAPTER}

3

\section{IMMUNOHISTOLOGY OF NASOPHARYNGEAL (WALDEYER'S RING EQUIVALENT) LYMPHOID TISSUE IN THE RAT}

P.J. Koornstra', A.M. Duijvestijn'2 , L.F.M. Vlek' ${ }^{2}$ E.M.H.A. Marres', P.J.C. van Breda Vriesman $^{2}$

1 Department of Otorhinolaryngology, Academic Hospital, Maastricht

2 Department of Immunology, University Maastricht, Maastricht

Acta Otolaryngol (Stockh) 1993; 113:660-667 


\begin{abstract}
Previously we have described the presence of Waldeyer's ring equivalent (WRE) lymphoid tissue in the rat, and pointed out the importance of such an experimental model for studying the immunological role of nasopharyngeal lymphoid tissue. Here we extend this work with immunohistological data in terms of compartmentalization and distribution of the various lymphoid and non lymphoid cells of this WRE lymphoid tissue in situ. WRE tissue consists of distinct $T$ cell and $B$ cell areas. $B$ cell areas predominate; they are located directly under the mucosal epithelium and consist mainly of follicles. These follicles frequently contain a germinal centre with $\operatorname{lgD}$ negative $\mathrm{B}$ cells interspersed with scattered CD4 (helper/inducer) $T$ cells. Follicular dendritic cells are present in the germinal centres. T cell areas, on the other hand, are predominantly present at the abluminal side of the WRE in inter follicular areas. In these areas high endothelial venules and both CD4 and CD8 (suppressor/cytotoxic) $T$ cell populations with a clear preponderance of CD4 over CD8 cells can be observed. MHC class II positive interdigitating dendritic cells are also scattered throughout these $T$ cell areas.

Mononuclear phagocytes (EDl-positive monocytes/macrophages) are scattered throughout the WRE, but especially in the $T$ cell areas. A sub population of (ED3-positive) mononuclear phagocytes, e.g. the lymphoid tissue macrophage, is exclusively scattered between the small blood vessels along the abluminal side of the lymphoid tissue. Here, plasma cells, including those of the $\operatorname{IgA}$ type, are located. The data show that nasopharyngeal lymphoid tissue in the rat can be considered as an immunologically fully equipped and active mucosal lymphoid organ presumably executing similar immune functions as the tonsils in the human Waldeyer's ring.

Key words: nasopharyngeal lymphoid tissue, immunohistology, rat, tonsil.
\end{abstract}




\section{Introduction}

The collection of the oro-nasopharyngeal lymphoid tissue in man is called Waldeyer's ring (WR) and belongs to the mucosa associated lymphoid tissues. These tissues are the first immunologically reactive organs encountered by inhalation and food antigens in the oronasopharynx. The largest and best known lymphoid tissues of WR, and those subjected clinically to tonsillectomy, are the paired palatine and the single pharyngeal tonsils. Although the human tonsils are easily accessible and extensively studied lymphoid organs, their precise immunological function and significance remain to be elucidated $(1,2)$.

These sub epithelial lymphoid organs may respond to oro-nasopharyngeal antigens through uptake by specialized epithelial $M$-cells $(3,4)$ or by antigen diffusion, operative analogous to Peyer's patch lymphoid tissues. Whether the tonsils, like the mucosal lymphoid tissue in the lung and the gut may control induction of specific immune responses on the one hand and specific tolerance on the other still has to be elucidated $(5,6,7)$. Also, the precise mechanisms which control the tonsillar immune responses, e.g. humoral versus cellular, and antibody isotype preference are not known precisely $(1,2)$. In order to address these questions we have initiated a series of studies on the WR equivalent (WRE) lymphoid tissue in an experimental rat model $(8,9)$. This paired lymphoid tissue of the rat is located in the nasopharymx and appears anatomically to be the upper most lymphoid organ in the respiratory tract $(3,9,10)$. Flow cytometry studies of WRE lymphocytes show the presence of B cells and CD4 (helper) and CD8 (suppressor/cytotoxic) T cell subsets. By using labeled lymphocytes it has been shown that WRE tissue is involved in intense trafficking of lymphocytes to and from this organ (9). To gain specific information about potential immune functioning we report here on immunohistological staining of WRE tissue. Monoclonal antibodies (MAb) to the various functionally well defined lymphoid ( $B$ cells, plasma cells, and $T$ cell subsets) and to non lymphoid cell types (macrophages, interdigitating cells, follicular dendritic cells, and endothelial cells) were used. The data show that WRE tissue can be considered an immunocompetent secondary lymphoid tissue which is capable of executing $B$ and $T$ cell functions, thus resembling the tonsils of the human WR.

\section{Material and methods}

\section{Animals}

Lewis rats were obtained from the Central Animal Research Facility of the University Limburg. The Netherlands. Animals had free access to food and water, and were used at the age of eight weeks.

\section{Removal of WRE and tissue processing}

Previous studies have demonstrated that rat nasopharyngeal lymphoid tissue is located in the left and right first nasal choane $(8,9)$. For removal of the WRE, rats were anesthetiszed and under a surgical microscope (Zeiss) the hard palate between the two molar rows was removed, thus exposing the rod shaped lymphoid organs in the nasal choanes. The organs were dis- 
sected in a non traumatical manner and kept in buffered saline on ice until processing. Other Jymphoid tissues such as lymph nodes, Peyer's patches and spleen were removed as well. Tissues were snap frozen in isopentane and stored at $-70^{\circ} \mathrm{C}$, or fixed in sublimate-formol (SF) for $2-4 \mathrm{th}$ and embedded in paraffin. SF fixation $(6 \% \mathrm{w} / \mathrm{v} \mathrm{HgCl2}, 10 \% \mathrm{w} / \mathrm{v}(37 \%)$-formalin, $5 \%$ glacial acetic acid in distilled water) allows detection of cytoplasmic immunoglobulin subtypes in paraffin sections without prior trypsinization as is required for formalin fixed tissue.

\section{Immunohistology}

A two-step immunoperoxidase technique was used for immunostaining of lymphoid tissue sections as previously described (11). Buriefly, $4 \mu \mathrm{m}$ thick frozen sections were acetone-fixed and air-dried using a fan. Sections were incubated for $1 \mathrm{~h}$ at room temperature with mouse monoclonal antibodies ( $\mathrm{mAb}$, Table 1$)$ to rat antigens.

\begin{tabular}{|lllrl}
\hline \multicolumn{5}{l}{} \\
\hline mAb & Specificity & Material & Dilution* & Source \\
\hline W3/13 & T cells (granulocytes) & Ascites & $400 \mathrm{x}$ & A. Williams \\
W3/25 (CD4) & T-helper cells (some macrophages) & Ascites & $200 \mathrm{x}$ & A. Williams \\
OX-8 (CD8) & T-cytotoxic/suppressor cells & Ascites & $400 \mathrm{x}$ & A. Williams \\
R-73 & T-cell receptor (alpha/beta) & Ascites & $1000 \mathrm{x}$ & T. Hünig \\
HIS-14 & B cells & Supernatant & $20 \mathrm{x}$ & F. Kroese \\
MARK & Ig kappa light chain & Ascites & $500 \mathrm{x}$ & SANBIO \\
MARA-2 & Ig alpha heavy chain & Ascites & $100 \mathrm{x}$ & SANBIO \\
MARG-1 & Ig gamma-1 heavy chain & Ascites & $100 \mathrm{x}$ & SANBIO \\
MARG-2a & Ig gamma-2a heavy chain & Ascites & $500 \mathrm{x}$ & SANBIO \\
MARG-2b & Ig gamma-2b heavy chain & Ascites & $100 \mathrm{x}$ & SANBIO \\
MARG-2c & Ig gamma-2c heavy chain & Ascites & $200 \mathrm{x}$ & SANBIO \\
ED-1 & Monocytes/macrophages & Ascites & $200 \mathrm{x}$ & C. Dijkstra \\
ED-3 & Lymphoid tissue macrophages & Ascites & $200 \mathrm{x}$ & C. Dijkstra \\
ED-5 & Follicular dendritic cells & Ascites & $200 \mathrm{x}$ & C. Dijkstra \\
HIS-19 & Ia-determinant & Supernatant & $20 \mathrm{x}$ & F. Kroese \\
RECA-1 & Pan-endothelial cell antigen & Ascites & $1000 \mathrm{x}$ & A. Duijvestijn \\
anti-keratim & Keratin & Supernatant & $50 \mathrm{x}$ & Euro Diag- \\
& & & & nostics \\
\hline T Dilutions were as recommended by suppliers or from titration studies on lymph node sections. & & &
\end{tabular}

Table 1: Antibodies used in the experiment.

Subsequently the sections were washed 3 times for $10 \mathrm{~min}$ in phosphate-buffered saline (PBS; $8.75 \mathrm{~g} / \mathrm{L} \mathrm{NaCl}, 1.41 \mathrm{~g} / \mathrm{L} \mathrm{Na} 2 \mathrm{HPO} 4.2 \mathrm{H} 2 \mathrm{O}, 0,21 \mathrm{~g} / \mathrm{L} \mathrm{KH} 2 \mathrm{PO} 4 ; \mathrm{pH} 7.3$ ) and incubated for 30 min. with a peroxidase conjugated second step antibody to mouse Ig (DAKO, Glostrup, Denmark) to which $3 \%$ normal rat serum was added. After washing, incubation occurred with a $0.1 \mathrm{mg} / \mathrm{ml}$ diaminobenzidine in PBS solution containing $0.1 \%$ hydrogen peroxidase for 
$10 \mathrm{~min}$, followed by rinsing the sections with tap water. Sections incubated with the peroxidase conjugated antibody only served as negative control. Blocking of endogenous peroxidase (EPO) occurred in the first series of staining experiments by a 10 min pre incubation of the sections in PBS contaiming 3\% $\mathrm{H}_{2} \mathrm{O}_{2}$. Since WRE tissue only occasionally showed a few EPO positive cells as shown by the near absence of staining in negative-control sections, no blocking was used in later experiments. For detection of cytoplasmic Ig in plasma cells, sections of SF-fixed (see above) and paraffin-embedded tissue was used. Four micron thick paraffin sections were cut and deparaffinized before staining. All sections were lightly counterstained with hematoxylin.

\section{Experimental design}

A series of five male 8-week-old rats was used for processing of frozen WRE tissue. From each animal the paired WRE organs were used. Two rats were used for processing of paraffin embedded WRE tissue. Tissues were positioned to allow longitudinal sectioning. Immunostaining with the various antibodies was carried out on cansecutive sections of WRE tissue to allow comparison of staining patterns. For detection and comparison of IgA versus other Ig producing plasma cells in the tissue, a series of more than 20 sections of paraffin-embedded material was alternately stained with MARA-2 (IgA) and MARK (all Ig classes). Results of WRE staining of individual rats were compared. Since the data allowed only qualitative and semi-qualitative evaluation, they were compared with previous quantitative flowcytometry studies of WRE cells (9).

\section{Results}

The paired nasopharyngeal lymphoid tissue in the rat consists of paired rod shaped lymphoid organs of about 8 by $1 \mathrm{~mm}$ which are present bilaterally at the bottom of the first nasal choane. This Waldeyer ring equivalent lymphoid tissue (WRE) is localized directly underneath the epithelial lining of the nasal mucosa. The WRE tissues from individual rats showed similar results as described below.

\section{Compartmentalization of the WRE lymphoid tissue}

Longitudinal sections stained with antibodies (W3/13 and MARK) directed to T and B cells respectively showed the tissue to consist of distinct $T$ and $B$ cell areas like other lymphoid tissues. When HIS-14, which recognizes a B cell-specific variant of the leukocyte common antigen, was applied, similar staining patterns as with MARK were obtained. B cell areas predominated over $T$ cell areas, and were mostly arranged in follicular structures aligning the mucosal epithelium (Fig. 1A). Frequently germinal centers were observed in these follicles, as nicely demonstrated by staining for $\operatorname{IgD}$ (with mAb MARD) which indicates germinal centers as dull or non stained $B$ cell areas (Fig. lB). T cell areas were predominantly located along the abluminal side of the WRE tissue, frequently in triangular arrangement between the $B$ cell follicles (see also Fig. $\mathrm{LA}$ ) resembling the inter follicular $\mathrm{T}$ cell areas seen in Peyer's patches. 

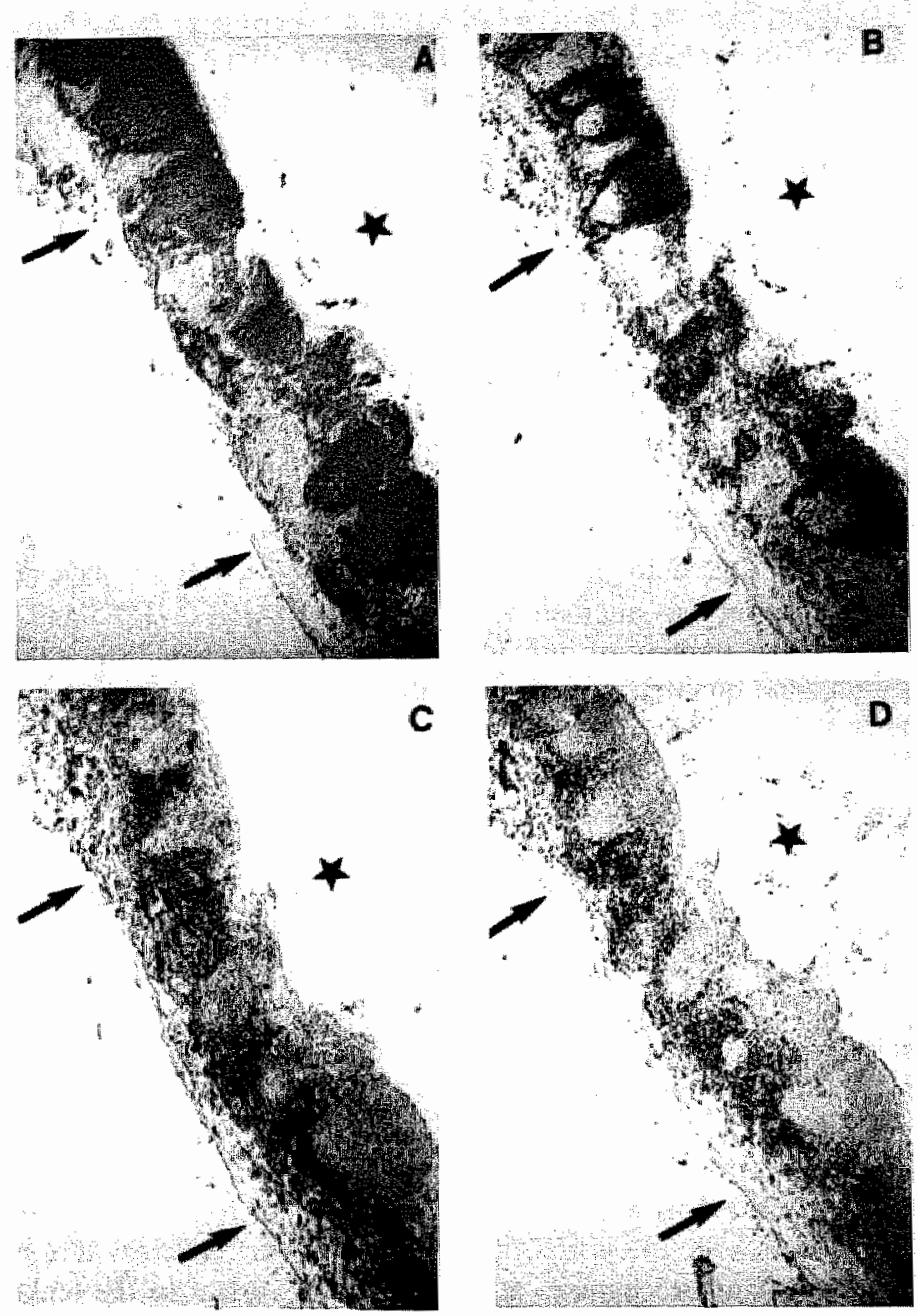

Fig. 1. Immunoperoxidase staining of consecutive frozen sections of rat WRE tissue.

Sections were counterstained with hematoxylin. (A) B cell areas stained with mAb MARK. Notice the arrangement of the $B$ cells in follicular structures. (B) IgD staining with mAb MARD showing that follicles contain germinal centers with $\mathrm{IgD}$ negative $\mathrm{B}$ cells. (C) $\mathrm{CD} 4 \mathrm{~T}$ cell staining with mAb W3/25. Notice that the $T$ cell areas are mostly arranged interfollicularly at the abluminal side of the WRE. (D) CD8 T cell staining with mAb OX-8 showing that (see fig. 1C) the numbers of CD8 cells are lower than for CD4 cells. Asterisks indicate the nasopharyngeal lumen; arrows point at the connective tissue lining the nasal septum. $x 62$ 
Staining with anti keratin antibodies, which identify epithelial cells, showed the epithelium lining the WRE. No staining of reticular cells in the T and B cell areas was seen. Comparable observations were made in human palatine and pharyngeal tonsils (data not shown), demonstrating the non epithelial nature of these reticular cells. In the epithelium that lines the WRE, lymphocytes were present, but a distinct lympho-reticular epithelial layer, as that seen in human palatine tonsils (2), was not noticed in the WRE.

\section{Lymphoid cells}

The T cell population (W3/13 positive) in the WRE tissue was predominantly confined to the $T$ cell areas, although scattered $T$ cells were observed in the $B$ cell areas, including germinal centers. Scattered T cells were also observed in the mucosal epithelial layer. Since granulocytes were almost absent in normal WRE lymphoid tissue (only occasionally some granulocytes, which stain strongly positive for EPO, were observed in the WRE connective tissue strands), the cross-reactivity of W3/13 with granulocytes did not interfere with $\mathbb{T}$ cell detection.

When mAb R73 (anti alpha/beta TCR) was used in WRE section staining, staining patterns were similar to W/13 staining. Thus virtually all $T$ cells in the WRE express the alpha/beta $T$ cell receptor, which was supported by fluorescent flow cytometry of WRE cell suspensions (data not shown). Detection of T-helper (CD4) and T cytotoxic/suppressor (CD8) cells with W3/25 and OX-8, respectively showed that CD4 cells outnumbered CD8 cells (Fig. 1 C\&D). Scattered $\mathrm{T}$ cells found in $\mathrm{B}$ cell areas were predominantly of the CD4-type, but also CD8 cells were seen. The observed $\mathrm{T}$ cells present in germinal centers were exclusively CD4 cells (Fig. 1C). B cells in WRE sections were identified by staining with HIS-14 or MARK, the latter being a mAb against the Ig kappa chain reacting with more than $95 \%$ of the $\mathrm{B}$ cell population (data not shown).
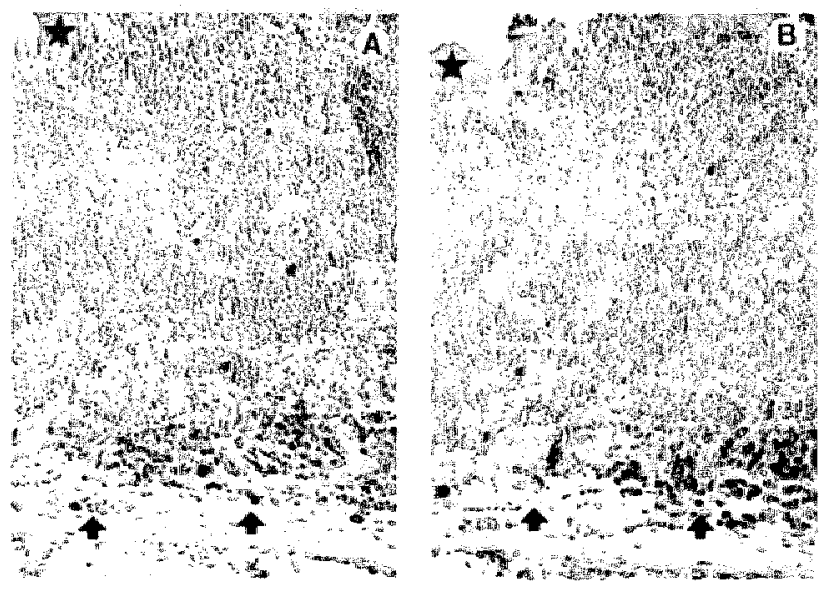

Fig 2. Immunoperoxidase staining of paraffin-embedded WRE tissue. Sections were counter; stained with hematoxylin.

(A) Staining of IgA plasma cells with mAb MARA-2. Notice the presence of plasma cells predominantly at the abluminal side of the WRE (arrows).

(B) Consecutive section stained with mAb MARK, showing the total pool of plasma cells. The asterisks indicate the mucosal epitheliall lining. $x 250$ 
Staining for lgM positive cells showed a similar staining pattern as obtained with MARK, whereas in $\mathrm{lgD}$ staining, as mentioned above, almost all $\mathrm{B}$ cells were positive, except for those in germinal centers. Only accasionally cells positive for one of the IgG subsets $(1,2 \mathrm{a}, 2 \mathrm{~b}$, or 2c); or for IgA were observed. Apparenty, most B cells in the WRE tissue are both IgM and IgD positive naive B cells. To define whether IgA plasma cells were present in the mucosal WRE tissue, deparaffinized sections were stained with mAb MARA-2. As shown in Fig. 2A, brightly-stained IgA plasma cells were observed predominantly at the abluminal side of the tissue around small blood vessels close to the bordering connective tissue. Plasma blasts with variable although less bright staining intensity were observed locally in the lymphoid tissue. Staining with mAb MARK for immumoglobulin kappa chains present in almost all plasma cells showed a somewhat higher frequency but a similar localization as found for the population of IgA plasma cells and plasma blasts (Fig. 2B). Apparently many of the WRE plasma cells are $\lg A$ producers.

\section{Non lymphoid (stromal) cells}

Lymphoid organs such as lymph nodes, Peyer's patches, spleen, and human tonsils contain various types of accessory cells with characteristic distributions in the lymphoid tissues. We stained WRE sections to define the presence and localization of accessory cells, including macrophage types, class II-positive dendritic cells and follicular dendritic cells in this tissue. ED- 4 positive monocytes/macrophages were observed scattered throughout the WRE tissue, especially in the $T$ cell areas. (Fig. 3A). When ED-3 was used to identify the population of lymphoid tissue-restricted macrophages, positive cells were found almost exclusively at the abluminal connective tissue side of the WRE (Fig. 3B). To identify class II MHC positive dendritic cells in WRE tissue, sections were stained with HIS-19, a mAb reactive with class II antigens. These class II positive interdigitating dendritic cells (IDC), which are extremely potent antigen presenting cells for T cells, were observed in the WRE tissue. They were present in the T cell areas (Fig. 3C), as seen also in other lymphoid tissues. HIS-19 also stained $\mathrm{B}$ cells, although less intensely so than IDC. In addition to IDC and B cells, the mucosal epithelial cells lining the WRE tissue were class II positive. The presence of follicular dendritic cells (FDC) in WRE tissue was studied by staining with $\mathrm{mAb}$ ED-5 which is specific for FDC in lymphoid tissues. ED-5 positive cells were locally observed in web-like patterns (Fig. 3D). In other lymphoid tissues the same pattern, representative for FDC in germinal centers of secondary $\mathbb{B}$ cell follicles, was found. 

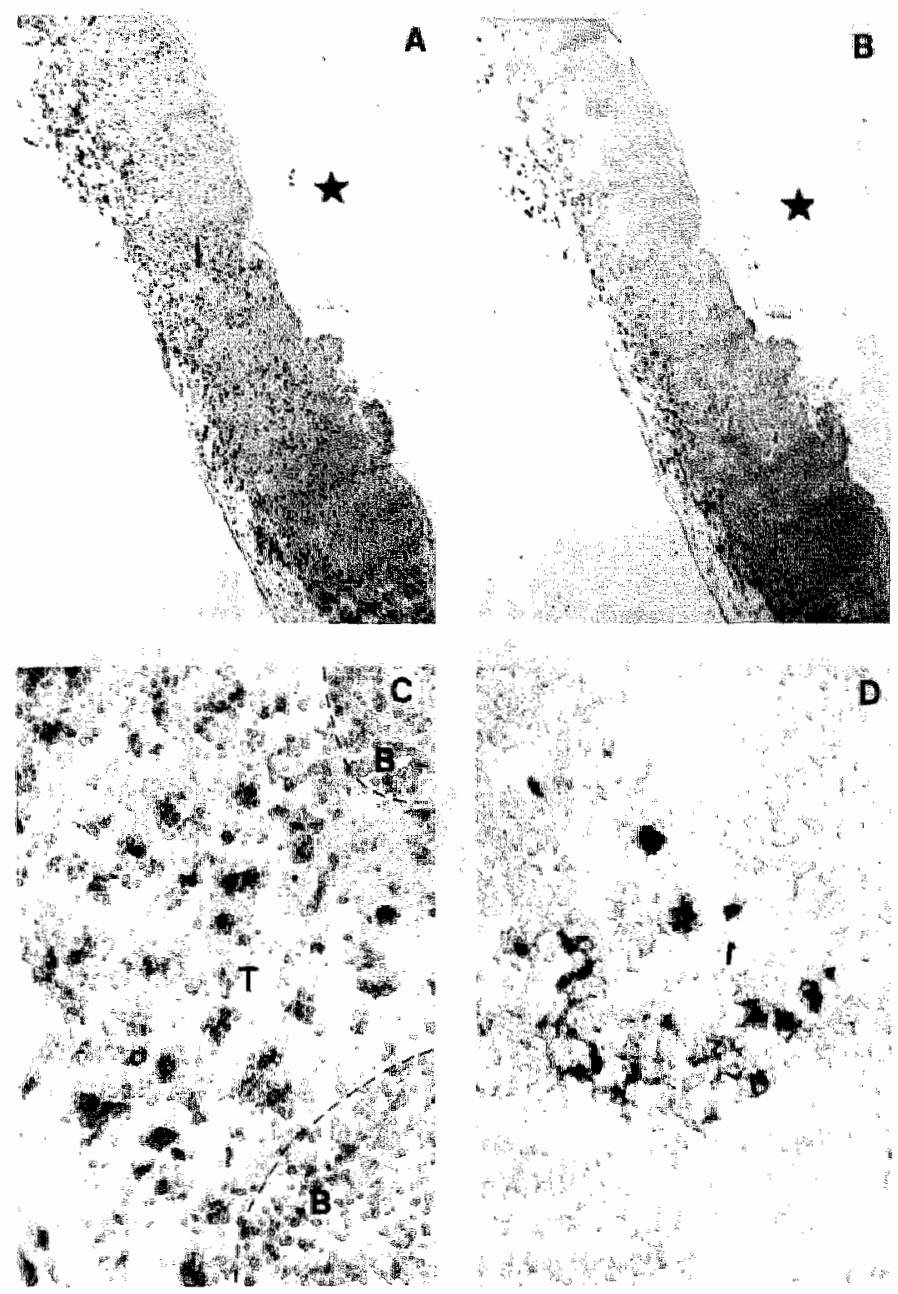

Fig. 3. Immunoperoxidase staining of frozen sections of rat WRE tissuc.

Sections were counterstained with hematoxylin. (A) Monocyte/macrophage staining with mAb ED-1. Notice that positive cells are scattered throughout the WRE. B cell follicles contain lower numbers of positive cells. (B) Staining with $\mathrm{mAb}$ ED-3 on a consecutive section showing that specialized lymphoid tissue macrophages are exclusively present at the abluminal side of the WRE. Asterisks indicate the nasopharyngeal lumen $A$ and $B$ : consecutive sections. $x$ 62.

(C) Staining with mAb HIS-19 for MHC class II positive cells. In the T cell area (T), class II positive interdigitating cells are present. $B$ cell areas $(B)$ are weakly positive. Dotted line distinguishes $T$ and $B$ cell areas. (D) Staining with $\mathrm{mAb}$ ED-5 defining follicular dendritic cells. Notice the more or less reticular staining pattern in the germinal center. $x 625$ 


\section{High endothelial venules (HEV)}

To define the blood vasculature in the WRE tissue, and in particular to identify HEV, sections were stained with mAb RECA-1 which specifically reacts with endothelial cells. As shown in Fig 4A, small blood vessels were found throughout the WRE tissue, but preferentially at the abluminal side in the $T$ cell areas and the connective tissue from which the blood supply to the tissue occurs. In the T cell areas $\mathrm{HEV}$, as characterized by plump endothelial lining and the presence of many adhering and transmigrating lymphocytes, were present, indicating a high rate of lymphocyte immigration (Fig. 4B)
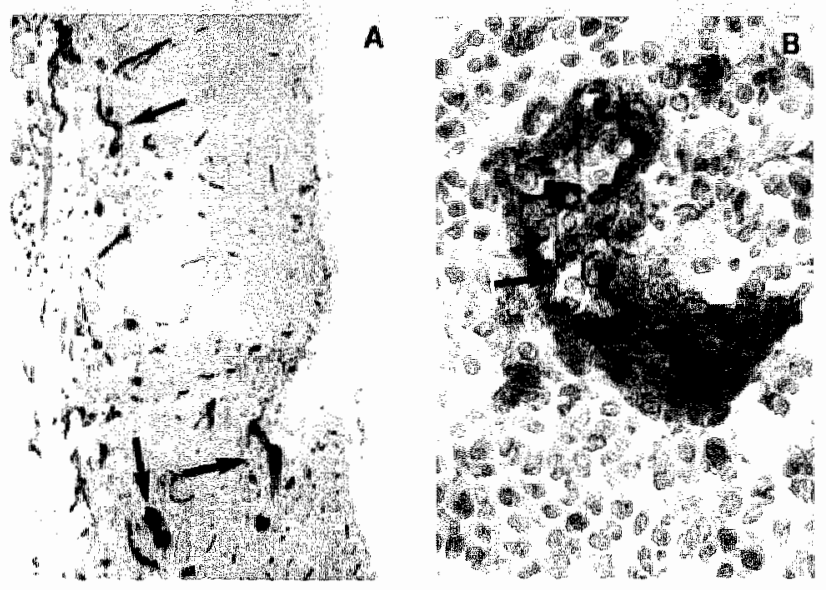

Fig. 4. Immunoperoxidase staining of frozen sections of rat WRE tissue. Sections were counterstained with hematoxylin.

(A) Staining with mAb RECA-1 defining endo-thelium of blood vessels. Small vessels are seen predo-minantly in the $T$ cell areas. Post-capillary high endothelial venules (HEV) are larger sized vessels (arrows). $\mathrm{x} 160$

(B) RECA-1 staining showing a HEV. Notice the thick endotheliall lining of the blood vessel and the presence of many intraluminal adhering lymphocytes (arrows). x 2800

\section{Discussion}

The WRE lymphoid tissue in the rat was studied immunohistologically. The paired rod-shaped rat WRE organs do not have numerous large crypts or a distinct lympho-reticular epithelium, and in this respect resemble the human pharyngeal tonsil more than the palatine tonsil (2). Staining patterns of consecutive sections using mAbs directed to $T$ and $B$ cells showed that the WRE is arranged in $T$ and $B$ cell compartments, as observed in other lymphoid organs. B cell areas predominated and were arranged in follicles aligning the mucosal epithelium. The dominance of $B$ cells is in accordance with previous studies where we showed by FACS analysis a T/B cell ratio of $0.5-0.7$ for the WRE (9). For human tonsils 
obtained from tonsillectomy because of chronic tonsillitis an average $T / B$ ratio of about 0.5 has been found (12-15). T cells in the WRE were located predominantly at the abluminal side in more or less triangular inter follicular (B cell) areas. Such localization of $T$ cell areas is also seen in human tonsils $(2,16)$. This arrangement of $T$ and $B$ cell areas was similar to the gut-associated Peyer's patch lymphoid tissue. That not all mucosa-associated lymphoid tissues have such a localization of $T$ and $B$ cell areas has been demonstrated in studies of bronchus associated lymphoid tissue (BALT) (17) describing a rather undetermined and variable position of $T$ and $B$ cell areas in rat BALT. BALT is located between the bronchus and the associated artery, and in guinea pigs the B cell areas were positioned next to this artery (18). In the B cell follicles of the WRE, germinall centers were noticed which had ED-5 positive follicular dendritic cells and activated $B$ cells as shown by the expression of IgM but not IgD (19). None of the animals used in this study had been challenged experimentally with antigen. This clearly demonstrates a continuous state of immunological activity in WRE tissue under physiological conditions. IgA plasma cells were found in the WRE ( although hardly any membrane IgA positive B cells were observed) and made up of a significant part of the total plasma cell pool in this tissue. These IgA plasma cells were predominantly localized at the abluminal side of the WRE in the vascularized area bordering the connective tissue layer from the nasal septum. Whether these plasma cells had progeny in the WRE or had immigrated into the tissue directly from the blood is not yet clear. However, cells with variable intensity of cytoplasmic IgA staining, presumably plasma blasts, were observed more central in the WRE. This implies that IgA plasma cells actually may be generated in the WRE, and suggests a role of the WRE in IgA production. T cells were mostly located in the small T cell areas, although some scattered $T$ cells were present in the $B$ cell areas. T cells in germinal centers were almost exclusively of the CD4 (helper) type, a phenomenon found also in other lymphoid tissues (20). CD4 T cells predominated over CD8 cells. In previous studies we found a CD4/CD8 ratio of about five for the WRE in FACS analysis (9). Such CD4/CD8 ratio is comparable to studies of human tonsils, showing a ratio of $5-6(21,22,23)$. The presence of $T$ cells in epithelium of the WRE suggests a role directly related to WRE immune function. In this respect the observation that the epithelial cells lining the WRE were MHC class II positive may be relevant to local presentation of soluble antigens to intra epithelial CD4 cells. If so, one might consider that these nasal intra-epithelial $\mathrm{T}$ cells, which presumably are activated/memory cells, analogous to intestinal intra-epithelial $T$ cells (24), can respond immediately upon antigenic challenge in the nasopharynx. The underlying WRE offers the unique microenvironment for subsequent immunoregulatory processes leading to an adequate immune response. For particulate antigens it has been demonstrated that specialized epithelial $M$ cells are involwed in the transport from the pharyngeal or intestinal Jumen to the associated WRE or PP lymphoid tissue respectively $(3,4,9)$. Processing and presentation of antigens to $T$ cells inside lymphoid tissues requires specialized antigen processing and presenting cells such as interdigitating dendritic cells (IDC) and macrophages. These cells were noticed in the WRE tissue (see also (4)). In this respect, the WRE can be considered an organ which may accurately process and present antigens in a local immune response. Interesting is the observation of ED-3 positive (lymphoid tissue) macrophages in the WRE. In other mucosal lymphoid tissues such as BALT and PP no or only sporadic ED-3 positive macrophages have been observed (18). Among the predominantly small blood vessels present in the WRE, we 
noticed numerous HEV. HEV were mostly located in the $T$ cell areas and contained numerous adhering and transmigrating lymphocytes from the blood, thus suggesting a high rate of lymphocyte inthux. Previously we have demonstrated that, with respect to immigration of Hymphocytes from the blood, the WRE collects many more lymphocytes per gram of tissue than Peyer's patch, but less than the lymph node (9). In conclusion, our data demonstrate that the rat nasopharyngeal lymphoid tissue can histologically be considered an immunologically active lymphoid organ and a member of the mucosa associated lymphoid tissues. Its resemblance to the human tonsils (reviewed in (2)) suggests analogous immunological functions for the rat WRE as for the human (pharyngeal) tonsil. Thus the rat WRE model may help to elucidate the immunological functions of the tonsil of man.

\section{Acknowledgements}

mAbs were kindly donated by Dr. A Williams (Oxford, United Kingdom), Dr. T. Hünig (München, Germany), Dr. C. Dijkstra (Amsterdam, The Netherlands), and Dr. F. Kroese (Groningen, The Netherlands), or were purchased from SANBIO B.V. Uden, The Netherlands) and from Euro-diagnostics bv (Apeldoorn, The Netherlands). 


\section{References}

1. Brandtzaeg P. Immune functions of human nasal mucosa and tonsils in health and disease. In: Bienenstock J, ed. Immunology of the lung and upper respiratory tract. New York: MoCraw Hill, $1984 ; 28-95$.

2. Brandtzaeg P. Immune functions and immumopathology of palatine and nasopharyngeal tonsils In: Bernstein $\rrbracket$, Ogra P, eds. Immunology of the ear. New York: Raven Press, 1987; 63-106.

3. Spit BJ, Hendriksen EGJ, Bruijntjes JP, Kuper CF. Nasal lymphoid tissue in the rat. Cell Tissue Res 1989; 255: 193.

4. Kuper CF, Koornstra PJ, Hameleers DMH, et al. The role of nasopharyngeal lymphoid tissue. Immunol Today $1992 ; 13: 219-224$.

5. Ivanoff $\mathrm{B}$, Fontagnes $\mathrm{AC}$, Jourdan $\mathrm{G}$. Secondary immune response to oral and nasal rough mutant strains on Salmonella typhimurium. Ann Immunol 1982; 133D; 61-70.

6. Holl $P G$, Sedgwick JD. Suppression of $\mathrm{IgE}$ responses following inhalation of antigen. Immunol Today $1987 ; 8: 14-15$.

7. Mattingly JA, Wakson BH.. Immunologic suppression after oral administration of antigen. 1. Specific suppressor cells formed in rat Peyer's patches after oral administration of sheep erythrocytes and their systemic migration. J Immunol 1978; 121: 1878-1883.

8. de Jong FICRS, van Breda Vriesman PJC, Vlek LFM. Basic mechanisms of the nasopharyngeal immune system. Clin Otolaryngol 1985; 10: 228.

9. Koornstra PJ, de Jong FICRS, Vlek LFM, Marres EHMA, Van Breda Vriesman PJC. The Waldeyer ring equivalent in the rat. A model for amalysis of oronasopharyngeal immune responses. Acta Otolaryngol (Stockh) 1991; 111: 591-599.

10. Hameleers DMH, van der Ende M, Biewenga J, Sminia T. An immunohistochemical study of the postnatal development of rat nasal associnted lymphoid tissue (NALT). Cell Tissue Res $1985 ; 256: 431-438$.

11. Duijvestijn AM. Kerkhove M, Bargatze RF, Butcher EC. Lymphoid tissue- and inflammation-specific endothellal cell differentation defined by monoclonal antibodies. $J$ Immunol 1987; 138: 713-719.

12. Plum $J$, van Cawwenberge $P$, De Smedt $M$. Phenotyping of mononuclear cells from tonsils and corresponding biopsies using a cytofluorimeter. Acta Otolaryngol (Stockh) 1986; 101: 129-134.

13. Brochier J, Samarut C, Bich-Thuy LT, Revillard JP. Study of human T and B lymphocytes with heterologous antisera. IV. Subpopulations in tonsil and adenoid cell suspensioms. Immunology $1987 ; 35: 827-835$. 
14. Rynmel-Dagöo $B$, Moller E, Waterfield E. Characterization of human adenoid cells using surface and functional markers for Hymphocyte subpopulations. Clin Exp Immunol 1977; 27 : 425-431.

15. Wilson JKV, Zaremba $\mathrm{L}$, Pitts AM, Pretlow TG, A characterization of human tonsillar lymphocytes after separation from other tonsillar cells in an isokinetic gradient of Ficoll in tissue culture medium. Am I Pathol 1976; $83: 341-358$.

16. Hoffman-Fezer G, Lohrs U, Rodt HV, Thierfelder S. Immunohistochemical identification of T and $B$ lymphocytes delineated by the unlabelled antibody enzyme method. III. Topographical and quantitative distribution of $\mathrm{T}$ and $\mathrm{B}$ cells in human palatine tonsils. Cell Tissue Res 1981; 216: $361-375$.

17. van der Brugge-Gamelkoorn GJ, Kraal G.The specificity of the high endothelial venule in bronchus associated lymphoid tissue (BALT). J Immunol 1985; 134: 3746-3750.

18. Sminia $T$, van der Brugge-Gamelkoorn GJ, Jeurissen SHM. Structure and function of bronchus-associated lymphoid tissue (BALT). Crit Rev Immunoll 1989; 9: 119-150.

19. Bailey DJ, Rainey H, Habeshaw JA. Immunoperoxidase analysis of $B$ and $T$ cell populations in human lymphoid follicles. Adv Exp Med Biol 1982; 149: 809-816.

20. Rouse $\mathrm{RV}_{\text {, Weissman }} \mathrm{IL}$, Ledbetter JA, Warnke RA. Expression of $\mathrm{T}$ cell antigens in mouse and human primary and secundary follicles. Adv Exp Med Biol 1982; 149: 751 1-756.

21. Dvoretsky $P$, Wood GS, Levy $R$, Warnke RA. T- lymphocyte subsets in follicular lymphomas compared with those in non-neoplastic lymph nodes and tonsils. Hum Pathol 1982; 13: 618625 .

22. McMillan EM, Wasik $R$, Everett MA. Identification of T-lymphocytes and T-subsets in human tonsils using monoclonal antibodies and the immunoperoxidase technique. Am J Clin Palhol $1981 ; 76: 737-744$.

23. van der Valk P, van der Loo EM, Jansen J, Daha MR, Meijer CJLM. Analysis of lymphoid and dendritic cells in human lymph node, tonsil and spleen. A study using monoclonal and heterologous antibodies. Virchows Arch (Cell Pathol) 1984; 45: 169-185.

24. Cerf-Bensussan N, Jarry A, Brousse N, Guy-Grand D. Phenotypical characteristics of intraepithelial lynphocytes isolated from normal human small intestine. Imhof BA, Berrih-Aknin S, Ezine S, eds. Lymphatic tissues and in vivo responses. New York: Dekker, 1991; 437-443. 


\section{CHAPTER}

4

\section{THE WALDEYER RING EQUIVALENT IN THE RAT A MODEL FOR ANALYSIS OF ORONASOPHARYNGEAL IMMUNE RESPONSES}

P.J. Koornstra', F.I.C.R.S. de Jong', L.F.M. Vlek ${ }^{2}$,E.H.M.A Marres', P.J.C. van Breda Vriesman $^{2}$

1 Department of Otorhinolaryngology, Academic Hospital, Maastricht

2 Department of Immunology, University Maastricht, Maastricht 


\section{Abstract}

By means of serial sectioning of the head and neck a paired, rod shaped, parachoanic lymphoid organ was identified in Lewis rats. Histological, ultrastructural studies and FACS analysis showed this organ to be a lympho epithelial organ with high endothelial venules (HEV) and a preponderance of $B$ over $T$ and $T$ helper over $T$ suppressor cells.

Consequently this organ resembles the pharyngeal tonsil of man, and is called the Waldeyer ring equivalent (WRE). The lymphatic drainage of this organ occurs predominantly to the deep, and to a lesser extent to the superficial cervical lymph nodes. Migration studies with ${ }^{51} \mathrm{Cr}$ labeled cells show that the WRE lymphoid cells migrate into the lymphoid organs with HEV (peripheral lympl nodes, Peyer patches and WRE). In this respect they resemble peripheral lymph node cells more than cells from the Peyer patches. Thus the WRE lymphoid tissue in the tat is undoubtedly involved in local oronasopharyngeal immune surveillance and may also contribute to mucosal and systemic immune responses.

Key words: nose, mucosa-associated lymphoid tissue, tonsil. 


\section{Introduction}

The organised oronasopharyngeal mucosa associated lymphoid system of man consists of pharyngeal-, palatine-, and lingual tonsils and is collectively called Waldeyer's ring. The precise role of this tissue in local and systemic immunity is not known and a suitable experimental animal model is lacking.

Nevertheless, tonsillectomy is one of the nost common surgical procedures in childhood. Experimental work in rodents on mucosa associated lymphoid tissue, e.g. the bronchus associated lymphoid tissue (BALT) (1) and gut associated lymphoid tissue (GALT) (2), has shown that intratracheal and oral (interstitial) administration of antigen can lead to both locall and systemic immune reactions. Recirculating lymphocytes appear to play an important role in the coordination and integration of these immune responses.

Recirculating lymphocytes are mobile cells which continuously migrate between peripheral lymphoid organs via lymph and blood for most of their life span. Independent of lymphoid lineage $(B, T$ or $T$ cell subsets), lymphocytes have the potency to migrate to mucosal and non-mucosall lymphoid tissues (e.g. lymph nodes, spleen and bone marrow) (3). This migration does not occur at random since the lymphocyte traffic into peripheral lymph nodes and mucosa associated lymphoid tissue is regulated in part by specialized endothelial cells in the post capillary venules; the so-called high endothelial venules (HEV). These high endothelial venules express differing ligands for receptor molecules on $T$ and $B$ cells (4). In vivo studies in rodents show B lymphocytes to home preferentially to Peyer patches. By contrast, T $1 \mathrm{ym}$ phocytes prefer migration into the lymph nodes (5), presumably because of different densities of receptor molecules for ligands expressed by the HEV of Peyer patch and peripheral lymph nodes respectively. These rodent studies appear relevant to man because in vitro studies in man (6) show mature T lymphocytes to bind preferentially to the HEV of peripheral lymph nodes, whereas B lymphocytes bind preferentially to the HEV of the GALT. The anatomy, histology and lymphoid cell phenotype of the tonsils of man indicate that they belong to the mucosa associated lymphoid tissue: they are lymphoepithelial organs with a predominance of follicles, HEV and an excess of B over T cells (7). Nevertheless, in man mature T lymphocytes from blood and spleen bind equally well to the HEV of the tonsil and peripheral lymph node in vitro (6). In order to examine the potential significance of this WRE for mucosal and systemic immune response we studied the migration of WRE cells into lymphoid and non-lymphoid tissues.

\section{Matrial and methods}

\section{Animals and surgery}

Young adult, 8 to 10 weeks old, inbred male Lewis rats, barrier raised and conventionally maintained, were obtained from the Department of Animall Services of this University. The paired lymphoid organs residing in the lateral walls of the first choana were removed as follows: after ether anaesthesia and exsanguination, the mucosa of the hard palate was dissected, using a stereomicroscope, in order to gain access to the first choana. Next the medial 
part of the hard palate was removed and the organs were dissected from their bony fossa. These organs are about $7 \mathrm{~mm}$ long, $\rrbracket \mathrm{mm}$ in cross diameter and each weighs approximately 4 mg.

\section{Morphological studies}

For topographic anatomical studies animals were killed by intracardiac injection with Nembutal ${ }^{10}$ and decapitated. That part of the head containing the oro-nasopharyngeal area was dissected, fixated in $4 \%$ formaldehyde and decalcifted in a mixture of equal parts of $8 \mathrm{~N}$ formic acid and $1 \mathrm{~N}$ sodium formate for 3 weeks. Next, the tissue was dehydrated, embedded into paraplast. Seriall $10 \mathrm{~km}$ sections were stained with hematoxylin and eosin.

Sections were screened lightmicroscopically in order to identify lymphoid structures. For lightmicroscopic and ultrastructural studies the parachoanic organs were dissected, fixated and stained according to standard techniques.

\section{Cell suspension}

For FACS analysis and migration studies, cell suspensions were prepared of both the parachoanic lymphoid argans and Peyer patches. Cells were teased out of the organs with needles in Hanks Balanced Salt Solution (HBSS) pH 7.4, supplemented with 2.5\% newborn calf serum at $4^{\circ} \mathrm{C}$. Peyer patches were dissected from the serosal site of the small bowel using a stereomicroscope. Cell suspensions of cervical and mesenteric lymph nodes were made by mincing the organs on a stainless steel grid in HBSS. Cell suspensions were washed in HBSS at $4{ }^{\circ} \mathrm{C}, 600 \mathrm{~g}$. Dead cells and debris were removed by layering cell suspensions on $12 \mathrm{~m} \rrbracket$ of Percoll $(6.0 \mathrm{ml} 82 \%$ Percoll overlaid with $6.0 \mathrm{ml} 30 \%$ Percoll) and by centrifuging at $800 \mathrm{~g}$ for $20 \mathrm{~min}$ at $22^{\circ} \mathrm{C}$. Lymphoid cells were removed from the interphase, washed and resuspended in HBSS. Such cell suspensions were over $90 \%$ wiable by trypan blue exclusion. When desired, the lymphoid cell suspensions were passed over a nylon wool column to obtain non-adherent $T$ cell-enriched fractions (8).

\section{${ }^{125}$ I IgG aggregates}

For studying the lymphatic drainage aggregated ${ }^{125} \mathrm{I}$ labeled IgG was injected together with methylene blue into the frontal part of such an organ after prior dissection of the local mucosa by means of a $10 \mu \mathrm{l}$ Hamilton syringe. Human $\operatorname{IgG}$ was isolated from serum by chromatography of a $50 \%$ (NH4) ${ }_{2} \mathrm{SO}_{4}$-dissolwed precipitate on DEAE-A50 Sephadex in PBS pH 7.3. The fall through peak was concentrated to $30 \mathrm{mg} / 1.0 \mathrm{ml}$ and was pure by immuno-electrophoresis. $\mathrm{IgC}$ at $1.0 \mathrm{mg} / 1.0 \mathrm{ml}$ was labeled with ${ }^{125} \mathrm{I}$ by means of chloramine T. Free iodine was removed by exclusion chromatography on 625 Sephadex. ${ }^{125} \mathrm{I} \lg \mathrm{G}$ thus prepared was over $95 \%$ precipitable in $10 \%$ trichloroacetic acid and had a specific activity of $0.25 \mathrm{Ci} / 1.0 \mathrm{~g}$ of $\lg \mathrm{G}(9.25$ $\mathrm{Gbq} / 1.0 \mathrm{~g}$ ). Aliquots of ${ }^{125} \mathrm{IgG}$ were added to cold $\mathrm{IgG}$ which was aggregated at $20 \mathrm{mg} / 1.0$ $\mathrm{ml}$ for $30 \mathrm{~min}$ at $63^{\circ} \mathrm{C}$, cooled $15 \mathrm{~min}$ on ice, spun $15 \mathrm{~min}$ at $2500 \mathrm{RPM}$ at $4^{\circ} \mathrm{C}$. Aggregates of restricted size without free monomeric $\operatorname{IgG}$ were obtained by centrifugation on a sucrose cushion and subsequent pooling of fractions with a refraction index of $1.366-1.389$, according to Nydegger et al. (9). 
The aggregates were stabilized by adding bovine serum albumen (BSA) to a concentration of $1 \%$ and stored for up to one year at $-70^{\circ} \mathrm{C}$, according to Kauffimann et al. (10).

\section{FACS analysis}

The composition of the Percoll purified lymphoid cell populations was determined by phenotyping using monoclonal antibodies to $B$ and $T$ lymphocyte subsets, and a fluorescence activated cell sorter (FACS IV, Becton Dickinson) in the indirect immunofluorescence technique. For this purpose $5.10^{5}$ to $1.10^{6}$ cells in $0.1 \mathrm{ml}$ HBSS were incubated with monoclonal antibody for $30 \mathrm{~min}$ at $4^{\circ} \mathrm{C}$, washed, and stained with fluoresceinated goat $\mathrm{F}(\mathrm{ab})_{2}$ anti mouse IgG (Cappel Lab, Cochraneville, Pennsylvania) (absorbed with rat $\mathrm{IgG}$ ) for $30 \mathrm{~min}$ at $4^{\circ} \mathrm{C}$. After two additional washes FACS analysis was performed using appropriate controls and FACS setting as described previously (11). Mouse anti-rat monoclonal antibodies included a $B$ cell membrane marker ( $O X 12)$, and markers for total $T$ cells ( $W 3 / 13)$ and $T$ helper $(W 3 / 25)$, $\mathrm{T}$ suppressor/cytotoxic cells (OX8). These monoclonal antibodies were purchased from Serotec, Instruchemie, Hilversum, the Netherlands.

In order to detect blast cells within the lymphoid cell population, DNA was pulse labeled in wivo by the infusion of bromodesoxyuridine (BrdU), a synthetic analogue of thymidine, $50 \mathrm{mg}$ per $\mathrm{kg}$ intravenously. The animals were sacrificed $60 \mathrm{~min}$ post injection. The BrdU incorporated into DNA was detected by incubation of the nuclei of ethanol fixed, pepsin digested. cells with a mouse monoclonal antibody directed to BrdU (12).

Subsequently, staining with fluorescein isothiocyanate conjugated rabbit anti mouse $\operatorname{IgF}(\mathrm{ab}) 2$ fragments (Dako F313) was done prior to analysis in the FACS, which was performed as described in detaill elsewhere (11).

\section{Lymphoid cell migration}

For migration studies lymphoid cell suspensions were labeled with $\mathrm{Na}_{2}{ }^{51} \mathrm{CrO}_{4}(370 \mathrm{Kbq}$ $[10 \mu \mathrm{Ci}]$ to $10^{6}$ cells in $20 \mu$ l of medium, for $45 \mathrm{~min}$ at $37^{\circ} \mathrm{C}$ ) to specific activities of $1 \mathrm{cpm}$ per 15 to 20 cells. After labeling, over $90 \%$ of the cells excluded trypan blue. Thus labeled cells are able to migrate in a normal pattern (13). Depending on the nature of the experiment, 2.5 to 15. $10^{6}$ cells in $0.5 \mathrm{ml}$ of medium were infused intravenously into syngeneic recipients. Recipients were sacrificed by exsanguination under ether anaesthesia after $20-24 \mathrm{~h}$, when a steady rate of migration can be expected (13). Organs of interest were excised, weighed and their radioactivity was counted for $1 \mathrm{~min}$ in a gamma spectrometer (LKB Compugarmma). After background subtraction, the radioactivity was expressed as the percentage of total infused dose per $1 \mathrm{~g}$ of tissue. Recovery of radioactivity, expressed as the percentage of total infused dose, was determined in each animal by adding the cpm of total spleen, liver, small bowel, cervical and mesenteric lymph nodes, parachoanic lymphoid organs and bone marrow (femur). Damaged cells release ${ }^{51} \mathrm{Cr}$ (sodium chromate) in wivo, which in turn is excreted into the urine (13). Therefore, comparable recoveries indicate comparable in vivo viability in the different experiments. 


\section{Results}

Identification, histology and drainage of the nasopharyngeal lymphoid tissue in the rat Serial crossisections of the oro-nasopharyngeal area were studied and revealed the presence of paired lymphoid tissue in the lateral wall of the first choane. This tissue was rod shaped and in animals 8 weeks of age $7 \mathrm{~mm}$ long, $1 \mathrm{~mm}$ in diameter and $4 \mathrm{mg}$ of weight; this lymphoid organ was located directly beneath the epithelial lining and was the only lymphoid tissue observed in the oronasopharynx. It can thus be considered as the Waldeyer ring equivalent (WRE) in the rat, which is stupported by the histology. Histologically these lymphoid organs show well defined lymphoid follicles with germinal centres and interfollicular lymphocyte areas. Occasionally crypts are seen in the epithelial lining (Fig. 1).

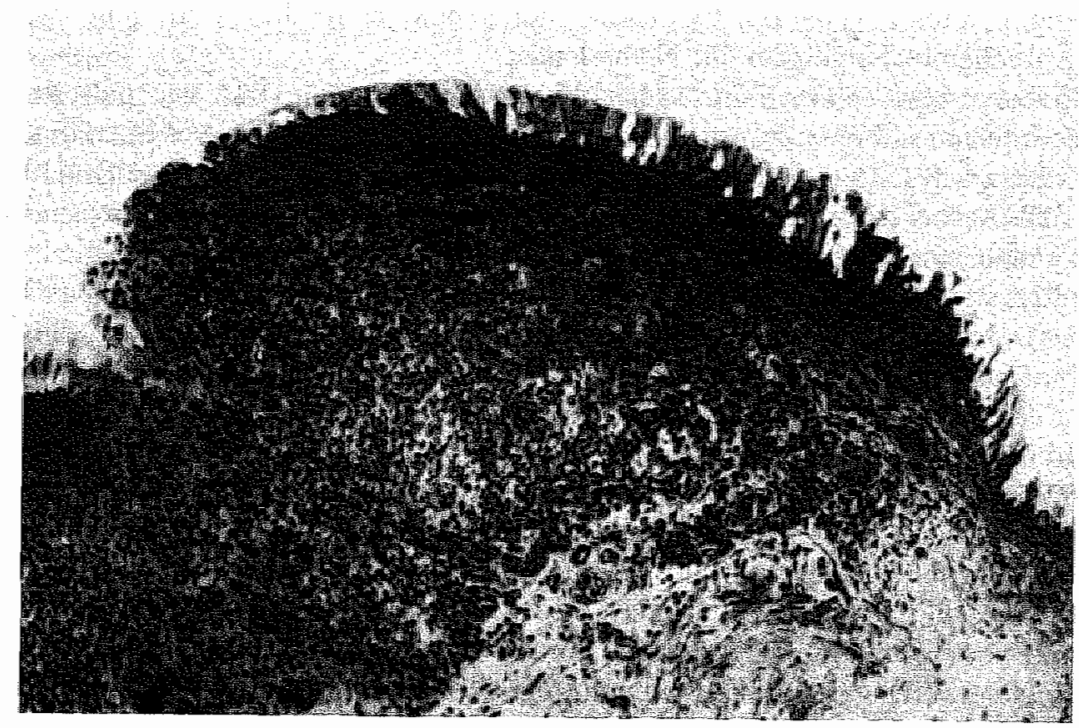

Fig. I. Waldeyer's ring equivalent of an 8-week-old rat (HE, $\mathbf{8 2}$ ). The lymphoid tissue under the epithelial lining contains a germinal center.

Ultrastructural studies showed the covering epithelium to resemble that of the Peyer patches in terms of the presence of $\mathrm{M}$ cells that have been described to transport antigen from the luminal side. In the interfollicular zones high endothelial venules (HEV) are present and the passage of lymphoid cells through the high endothelial venules can readily be visualized by electron microscopy (Fig. 2) (1.4). 

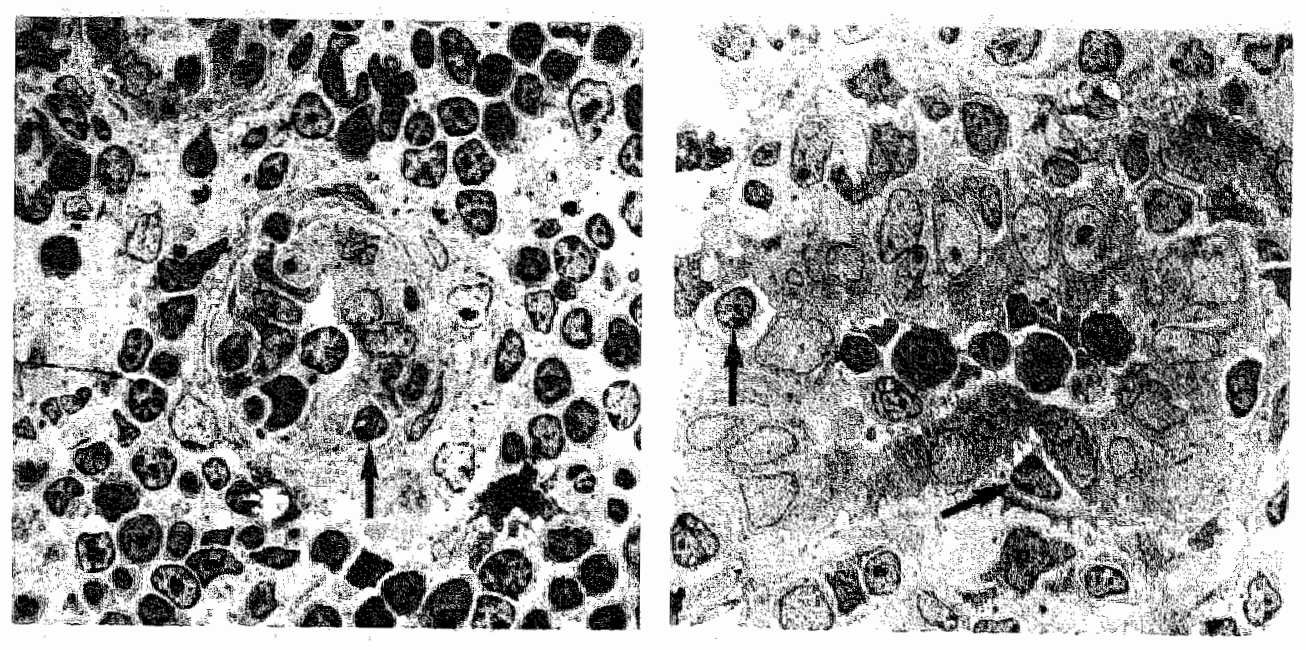

Fig. 2. Electron micrographs ( $x$ 1680 of a high endothelial venule in the Waldeyer ring equivalent of an 8-week-old rat (a) and in the palatine tonsil of an 8-year-old boy, who underwent tonsillectomy previous to plastic surgery of the soft palate (b). Note lymplioid cells (arrows) passing in between the cuboidal-cylindric endotheliall cells.

In order to study the lymphoid drainage aggregated ${ }^{125} \mathrm{I}$ labeled $\operatorname{IgG}$ was injected into one WRE by means of a Hamilton syringe; animals which showed extravasation of methylene blue were excluded from the study. Aggregated-but not monomeric-lgG showed localization in the deep and to a lesser extent in the superficial cervical nodes, which was readily apparent one hour after injection (Table 1).

\section{Facs analysis}

Percoll purified cell suspensions of WRE, Peyer patches, cervical and mesenteric lymph nodes were analyzed by $\mathrm{FACS}$. Cells from the WRE very much like those from the Peyer patches show a preponderance of B cells (OXI2 positive) over $T$ cells (W3/3 positive) when compared to cervical and mesenteric lymph node cell suspensions (Fig. 3). Phenotypically $T$ helper cells (W3/13 positive) outnumbered the T suppressor/cytotoxic cells (OX8 positive) in the cell population of WRE, Peyer patches, cervical and mesenteric lymph nodes. BrdU positive cells, which can be considered to represent blasts (12), constituted $3.4 \%$ of the cell suspension of the WRE, $4 \%$ of the cell suspension of the Peyer patches and $1.2 \%$ of the cellsuspension from the mesenteric lynuph node. 


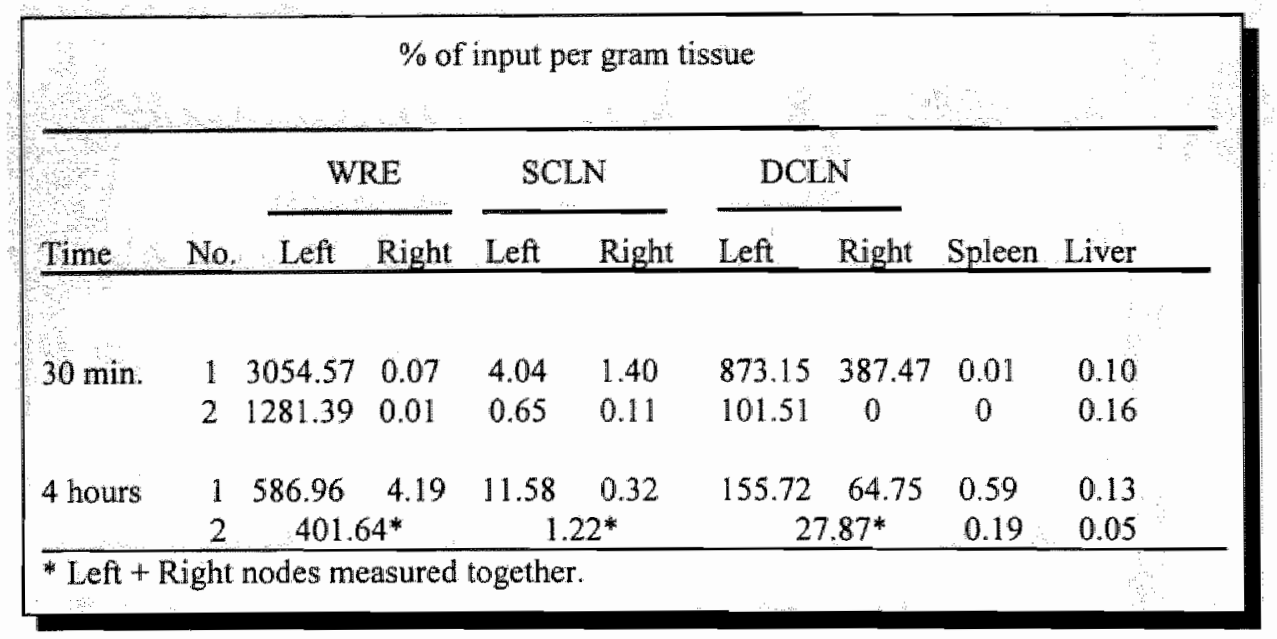

Table 1. Distribution of intra WRE/NALT injected humam IgG aggregates ${ }^{125}$ I labeled.

\section{Migration of WRE lymphocytes}

The migration of ${ }^{51} \mathrm{Cr}$ labeled WRE lymphoid cells was compared with identically labeled cells from Peyer patch and cervical and mesenteric lymph node cell suspensions, 20-24 h after intravenous infusion. In order to ensure that differences in migration patterns between various cell populations were not due to different in vivo viabilities, the recovery of ${ }^{51} \mathrm{Cr}$ was determined. The recoveries were found to be of comparable magnitude (Table 2). It is clear (Table 2) that WRE cells migrate to lymphoid organs which possess high endothelial venules: e.g. mesenteric nodes, cervical nodes, WRE and Peyer patches. In this respect they resemble the cells from cervical and mesenteric nodes. The WRE cells differ from the latter two populations in terms of a lesser migration into the small bowel and a greater migration into the liver but do resemble the lymphoid cells from the Peyer patches (Table 2). In order to determine whether or not the migration of WRE cells was dependent on the large percentage of $B$ cells, WRE cells were enriched for T cells by nylon wool passage. Cell suspensions thus treated contained 75 to $80 \%$ of $W 3 / 13$ positive cells and $3 \%$ of $O X 12$ positive B cells. The migration pattern of these $T$ cell enriched populations did not differ qualitatively from that of unfractionated WRE cells although quantitatively an increased migration into the cervical nodes was observed (Table 2). 


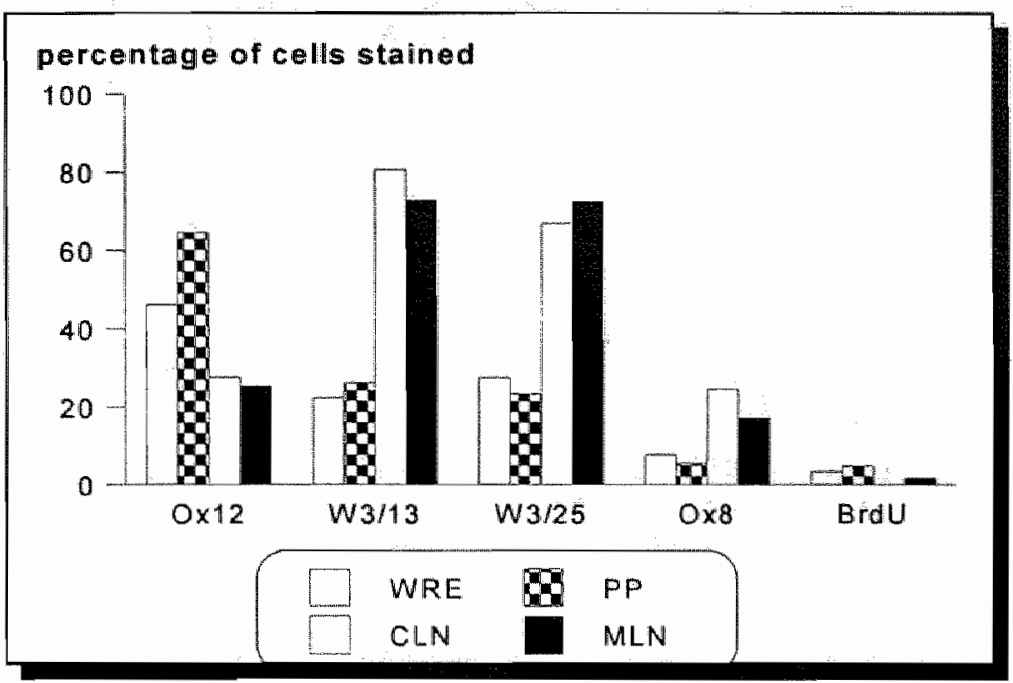

Fig.3. Phenotypic analysis of percoll purified cell suspensions from the Waldeyer ring equivalent (WRE), Peyer patches (PP), cervical lymph node (CLN) and mesenteric lymph node (MLN) of 8-week-old rats. There is a preponderance of $B$ cells $(0 \times 12$ positive) over $T$ cells (W3/13 positive) in the Waldeyer ring equivalent and Peyer patches when compared to the cervical and mesenteric lymph node. There is a preponderance of $T$ helper cells (W3/25 positive) over $T$ suppressor/cytotoxic cells ( $\mathrm{OX8}$ positive) in all organs. Blast cells (BrdU positive) constitute a minor part of the cell suspension from all organs.

\section{Discussion}

The mean findings of this study are twofold. First, histologically and in terms of lymphoid cell composition the paired parachoanic lymphoid organs of the rat resemble the pharyngeal tonsil of man $(3,7)$. However, they are lacated in a slightly different anatomical region. We consider these organs to be the Waldeyer ring equivalent (WRE) since on serial sectioning these are the only well structured lymphoepithelial organs found in the head and neck of the rat. Their lymphatic drainage to the deep and to a lesser extent superficial cervical lymph nodes is consistent with such a view. The presence of inbred strains of rats allowed us to assess the migration of the WRE lymphocytes in vivo. Both WRE and Peyer patches are mucosa associated lymphoid organs. Their cell suspensions are alike in terms of lymphoid phenotype (a preponderance of $\mathrm{B}$ over $\mathrm{T}$ cells and of $\mathbb{T}$ helper cells over suppressor/cytotoxic cells) but their migration patterns in vivo differ. The WRE cells migrate well into lymphoid organs with HEV, (e.g. WRE, peripheral lymph nodes and Peyer patches) as do peripherall lymph node cells. In contrast to peripherall lymph node cells and more like Peyer patch cells they have a greater tendency for hepatic trapping (Table 2). 
Uptake in percents of total infused dose per 1 gram of organ ${ }^{b}$

\begin{tabular}{|c|c|c|c|c|c|c|c|c|c|c|}
\hline $\begin{array}{l}\text { Recov } \\
\text { of cells }\end{array}$ & $\begin{array}{l}\text { No } \\
\text { exp. }\end{array}$ & WRE & $\mathrm{CLN}$ & MLN & $\begin{array}{l}\text { Small } \\
\text { bowel }\end{array}$ & $\mathrm{PP}$ & $\begin{array}{l}\text { Bione } \\
\text { marrow }\end{array}$ & Spleen & I Liver & ery \\
\hline WRE & 6 & $\begin{array}{r}10,32 \\
(1.61)\end{array}$ & $\begin{array}{r}9.82 \\
(0.67)\end{array}$ & $\begin{array}{r}14.70 \\
(2.36)\end{array}$ & $\begin{array}{r}0.26 \\
(0.05)\end{array}$ & $\begin{array}{r}6.13 \\
(0.47)\end{array}$ & $\begin{array}{r}0.81 \\
(0.11)\end{array}$ & $\begin{array}{r}52.05 \\
(3.51)\end{array}$ & $\begin{array}{r}2.86 \\
(0.40)\end{array}$ & $\begin{array}{r}60.03 \\
(3.20)\end{array}$ \\
\hline WRE & 4 & 8.55 & 16.00 & 18.39 & 0.30 & n.d. & 0.77 & 58.85 & 2.80 & 65.69 \\
\hline $\begin{array}{l}\text { Nylon w } \\
\text { purified }\end{array}$ & & $(1.05)$ & $(1.30)$ & (1.80) & $(0.05)$ & wid. & $(0.12)$ & $(4.62)$ & $(0.38)$ & $(2.75)$ \\
\hline CINN & 6 & $\begin{array}{r}13.70 \\
(3.01)\end{array}$ & $\begin{array}{l}21.57 \\
(1.66)\end{array}$ & $\begin{array}{r}26.94 \\
(1.97)\end{array}$ & $\begin{array}{r}1.72 \\
(0.22)\end{array}$ & $\begin{array}{r}8.62 \\
(1.49)\end{array}$ & $\begin{array}{r}0.58 \\
(0.11)\end{array}$ & $\begin{array}{l}60.03 \\
(3.76)\end{array}$ & $\begin{array}{r}1.96 \\
(0.27)\end{array}$ & $\begin{array}{r}67.42 \\
(3.48)\end{array}$ \\
\hline MLN & 6 & $\begin{array}{r}13.29 \\
(4.15)\end{array}$ & $\begin{array}{l}20.66 \\
(1.48)\end{array}$ & $\begin{array}{l}27.29 \\
(2.16)\end{array}$ & $\begin{array}{r}2.53 \\
(0.39)\end{array}$ & $\begin{array}{r}11.62 \\
(0.90)\end{array}$ & $\begin{array}{r}0.67 \\
(0.13)\end{array}$ & $\begin{array}{l}55.08 \\
(4.03)\end{array}$ & $\begin{array}{r}2.00 \\
(0.12)\end{array}$ & $\begin{array}{l}63.40 \\
(1.13)\end{array}$ \\
\hline $\mathrm{PP}$ & 6 & $\begin{array}{r}2.17 \\
(0.32)\end{array}$ & $\begin{array}{r}1.65 \\
(0.13)\end{array}$ & $\begin{array}{r}3.41 \\
(0.24)\end{array}$ & $\begin{array}{r}0.45 \\
(0.04)\end{array}$ & $\begin{array}{r}2.16 \\
(0.59)\end{array}$ & $\begin{array}{r}0.80 \\
(0.27)\end{array}$ & $\begin{array}{l}28.90 \\
(2.73)\end{array}$ & $\begin{array}{r}3.93 \\
(0.42)\end{array}$ & $\begin{array}{l}60.36 \\
(2.16)\end{array}$ \\
\hline $\begin{array}{l}\text { PP } \\
\text { Nylon wo } \\
\text { purified }\end{array}$ & $\begin{array}{r}4 \\
\text { ol }\end{array}$ & 4.08 & 4.94 & 6.22 & $\begin{array}{r}0.21 \\
(0.02)\end{array}$ & n.d. & $\begin{array}{r}0.61 \\
(0.06)\end{array}$ & 35.42 & 4.45 & 66.67 \\
\hline $\begin{array}{l}\text { Migra } \\
\text { node ( } \\
\text { The re } \\
\text { their } \mathrm{r} \\
\text { organ } \\
\text { Betwe } \\
\text { The re } \\
\text { patche } \\
\text { Mean }\end{array}$ & $\begin{array}{l}\text { par } \\
\text { over } \\
\text { excll } \\
\text { veigh }\end{array}$ & $\begin{array}{l}\text { s were } \\
\text { ivity co } \\
\text { ent of } \\
\text { ritheses } \\
\text { represe } \\
\text { ded, in } \\
\text { of liver }\end{array}$ & $\begin{array}{l}\text { rified } \\
\text { ted in } \\
1 \text { infus } \\
\text { tandar } \\
\text { s the st } \\
\text { rcent } 0 \\
0.36 \mathrm{~g}\end{array}$ & $\begin{array}{l}\text { fter } 20- \\
\text { gamma } \\
\text { d dose } \\
\text { deviati } \\
\text { n of the } \\
\text { total in } \\
\text { SD: } 1.0\end{array}$ & $\begin{array}{l}\mathrm{h} \text { and } \mathrm{tl} \\
\text { intillati } \\
\text { epresen } \\
\text { dioacti } \\
\text { Mean }\end{array}$ & $\begin{array}{l}\text { he orga } \\
\text { ion cou } \\
\text { ited. } \\
\text { vity of } \\
\text { weight }\end{array}$ & $\begin{array}{l}\text { of inte } \\
\text { r. The }\end{array}$ & twer & Peyer & $\begin{array}{l}\mathrm{l} \text { and } \\
\mathrm{g} \text { of }\end{array}$ \\
\hline
\end{tabular}

Table 2. Migration of ${ }^{\text {st }} \mathrm{CR}$ labeled lymphoid cells.

The increased hepatic trapping of cells from Peyer patches and WRE is unlikely to be due to differences in cell viability since the $24 \mathrm{~h}$ excretion of sodium chromate $\left({ }^{51} \mathrm{Cr}\right)$ into the urine, which is a sensitive measure of cell viability (13), was identical for cell suspensions of peripheral lymph nodes and Peyer patches as is also reflected in comparable recovery rates (Table 2). The increased hepatic trapping of WRE and Peyer patch cell suspension could also be due 
since no ${ }^{31} \mathrm{Cr}$ labeled natural killer cells could be flushed out of the liver (Koornstra et al., unpublished observations) using the technique of Bouwens et al. (16). The increased "uptake" of Peyer patch and WRE cells by the liver is more likely to be due to migration of lymphocytes into the hepatic parenchyma as is also suggested by the observation that this increased hepatic uptake was equally observed in T cell enriched cell population (Table 2). It has recently become clear that in the rat lymphoid cells residing in the liver are capable of mounting specific IgM responses (17) and it is tempting to suggest that the migration of lymphocytes into the liver may be associated with such immune responses.

The migration of lymphocytes by HEV is mediated by receptor molecules present on lymphocytes and ligands (for these receptor molecules) present on HEV: T and B cells express different densities of these receptor molecules. "Therefore, differences in migration behaviour between WRE and Peyer patch cells in comparison to peripheral lymph node cells (Fig. 3) might be the result of the different percentages of $\mathrm{T}$ over $\mathrm{B}$ cells in these organs. This in an unlikely explanation since $T$ cell enriched lymphoid cells from the WRE showed a migration pattern comparable to that of unfractionated WRE cells (Fig. 3). Nor can the observed differences in migratory behaviour be explained by differing amounts of blast cells since BrdU positive cells -which can be taken to represent blast cells (18)-constitute only a very small percentage of the various cell populations (Fig. 3). Thus the differences found in in vivo migration of lymphoblasts from mucosal and peripheral lymph node origin appear immaterial to the interpretation of our results after in vitro expansion. Results may, however, be influenced by differences in B cell isotypes (Koornstra, Duijvestijn, Marres, Van Breda Vriesman) and $T$ cell subsets of the various cell populations used (Fig. 1). This is so for in rodents in situ labeling of Peyer patches showed phenotypically suppressor/cytotoxic $\mathrm{T}$ cells to migrate to a far greater extent compared to phenotypically $T$ helper cells (19). Thus additional studies using enriched $\mathrm{T}$ cell subsets and $\mathrm{B}$ cell isotypes are required to address this question. Our data show that the WRE is a mucosa associated lymphoid organ; its lymphoid cells migrate in such a fashion that these cells can be taken to influence local and systemic immune responses.

\section{Acknowledgements}

We would like to thank Dr. A.M. Duijvestijn and Dr. G.D. Majoor for critical reading of the manuscript, $H$. van Rie for technical assistance in histological work, and F. TengVangrootloon for secretarial support. 


\section{References}

1. van der Brugge-Gamelhoorn $G J$, Claassen E, Sminia T. Anti-TNP forming cell in bronchus associated lymphoid tissue and paratracheal nodes after intratracheal priming and boosting with TNP-KLH. Immunol 1986; 405-409:

2. Mattingly JA, Waksman BH. Immunological suppression after oral administration of antigen. I. Specific suppressor cells formed in rat Peyer patches after oral administration of sheep erythrocytes and their systemic migration. J mmunol 1978; $121: 1878-1883$.

3. Gowans JL, Knight EJ. The route of recirculating lymhocytes in the rat. Proc Roy Soc Ser 1964; BIS 9:257-282.

4. Woodruff JJ, Clarke LM, Chin YH. Specific cell-adhesion mechanisms determining migration pathways of recirculating lymphocytes. Ann Rev Immunol 1987; 5: 201-222.

5. Stevens SK, Weissman IL, Butcher EC. Differences in the migration of B and T lymphocytes: organ selective localization in wivo and the role of lymphocyte-endothelial cell recognition. J Immunol 1982; 128: 844-851.

6. Pals ST, Kraal G, Horst E, de Groot A, Scheper RJ, Meyer CJLM. Human lymphocyte high endothelial venule interaction: organ selective binding of $T$ and $B$ lymphocyte populations to high endothelium. I Immunol 1986; 137: 760-763.

7. Plum $J$, van Cauwenberge $P$, De Smedt $M$. Phenotyping of mononuclear cells from tonsils and corresponding biopsies using a cytofluorometer. Acta Ololaryngol (Stockh) 1986; 101: 129-134.

8. Julius $\mathrm{MH}$, Simpson E, Herzenberg LA. A rapid method for the isolation of functional thymus derived murine lymphocytes. Eur J Immunol 1973; 3: 645-649.

9. Nydegger UE, Svehag SE Improved standardization in the quantitative estimation of soluble immune complexes making use of an international reference preparation. Clin Exp Immunol $1984,58: 502-509$.

10. Kauffimann RH, van Es LA, Daha MR. Aggregated human immunoglobulin G stabilized by albumin: A standard for immune complex detection. J Immunol Meth 1979; 31: 11.-22.

11. Nagelkerken LM, Schutte $B$, Stet RJM, wan Breda Vriesman PJC. Recognition of rat dendritic cells by a monoclonal antibody. Scand IImmunol 1987; 26:347-353.

12. Schutte B, Reynders HMJ, Bosman FT, Blijham GH. Studies with antibromodesoxyuridine antibodies. II. Simultaneous immunocytochemical detection of antigen expression and DNA synthesis by in vivo labelling of mouse intestinal mucosa. Histochem Cytochem 1987; 35:371374. 
13. van Breda Vriesman PJC, Swanen-Sierag L, Vlek LFM. Cytotoxic and enthancing properties of early gamma-M alloantibodies elicited by first set renal allografts. Transplantation 1975; 20: 385-392.

14. Olahl. The structure of tonsils. In: Antoni F, Staub M, eds. Tonsils. Structure, immunology and biochemistry. Budapest: Akademia Kiado 1978; 5-49.

15. Bouwens L, Wisse E. Immuno-electron microscopic characterization of large granular lymphocytes (natural killer cells) from rat liver. Eur J Immunol 1987; 17: 1423-1428.

16. Bouwens $L$, Remells $L_{\text {, Baekland }}$, van Bossuyt H, Wisse E. Large granular lymphocytes or "Pit cells" from rat liver: ¿solation, ultrastructural characterization and natural killer activity. Eur J Immunol 1987; 17: 37-42.

17. Carter L, Barrington PJ, Cooper GN, Jackson GDF. Antibody synthesis in the rat liver: an association between antibody-forming cells in the liver and biliary antibodies following intravenous injection of horse erythrocytes. Int Arch Allergy Appl Immunol 1987; 82: 153-158.

18. Jung TM, Gallatin WM, Weissmann IL, Dailey MO. Down regulation of homing receptors afer T cell activation. J Immunol 1988; 141: 4110-4117.

19. Jeurissen SHM, Sminia T, Kraal G. Emigration of suppressor T cells from Peyer patches. Cell Immunol 1984; 85: 264-269. 


\section{CHAPTER}

5

\section{TONSILLAR (WALDEYER'S RING EQUIVALENT) LYMPHOID TISSUE IN THE RAT: \\ LYMPHOCYTE SUBSET BINDING TO HIGH ENDOTHELIAL VENULES (HEV) AND IN SITU DISTRIBUTION}

P. Koornstra', A.M. Duijvestijn'ㄱ, L.F.M. Vlek ${ }^{2}$, E.H.M.A. Marres', P.J.C. van Breda Vuiesman' ${ }^{2}$

1 Department of Otorhinolaryngology, Academic Hospital, Maastricht

2 Department of Immunology, University Maastricht, Maastricht

Reg Immunol 1992; 4: 401-408 


\section{Abstract}

We have studied lymphocyte traffic to the Waldeyer ring equivalent (WRE) Jymphoid tissue of the rat, by measuring the in vitro binding of various lymphocyte subsets to high endothelial venules (HEV) in the WRE. In addition, we studied the in siru distribution of these lymphocyte subsets. WRE tissue consists of $B$ and $T$ cell areas; the latter contain HEV. $B$ cells outnumber $T$ cells, and $T$ helper (CD4) cells outrumber $T$ suppressor/cytotoxic (CD8) cells ( $T-B$ ratio $=0.7 ;$ CD4-CD8 ratio $=5.1$ ). In vitro studies of lymphocyte binding showed that lymphocytes adhere almost equally well to $\mathrm{HEV}$ in WRE tissue as to HEV in lymph node (LN) tissue, and much better to HEV in WRE than to HEV in Peyer's patch (PP) tissue. T cells bind better than B cells to HEV in WRE (T-B binding ratio $=1.8$ ), and $C D 8$ cells better than CD4 cells (CD8-CD4 ratio of 2.9-3.2, dependent on cell source). The observed preference of $T$ over $B$ cells in binding to HEV is not reflecting the distribution of these lymphocyte sets in situ. In this respect the WRE takes a unique position, since in other lymphoid organs T-B binding ratios parallels $T$ and $B$ cell distribution in situ. This may suggest a much more rapid passage of $T$ cells through the WRE than through other lymphoid tissues, although other mechanisms cannot be ruled out. "The CD8-CD4 binding ratio to HEV in WRE contrasts with in situ distribution of these cells also; however, this is found for LN and PP lymphoid tissue too. Interestingly, the highest binding ratio of CD8 versus CD4 cells is found for HEV of the WRE. We conclude that WRE lymphoid tissue is highly involved in lymphocyte recirculation. The fact that $T$ cells bind much better than $B$ cells to HEV in WRE, may point at a prevalence of $T$ cell immigration and a significant role of these cells in immune functioning of WRE tissue. 


\section{Introduction}

Recently, an organized paired mucosal lymphoid organ in the first nasal choane of the rat has been described (1-4). These organs are considered to be an experimental model for studying. the immunological function of lymphoid structures in the oro-nasopharynx (Waldeyer's ring). This tissue is the first in line for defense to incoming air-born, and possibly also food antigens, and therefore an essential role in the regulation of immune responses to such antigens is expected. Immune competency of oro-nasopharyngeal lymphoid tissue depends, as it does for all lymphoid tissues, on the recruitment of the various recirculating lymphocyte sets from the blood. The process of recirculation allows the lymphocyte to encounter antigen and to participate in immune regulatory processes in a particular lymphoid organ $(5,6)$. The entrance rate of lymphocytes, in combination with their local retention and proliferation, determines the distribution profiles in lymphoid organs in situ. For example, the B cell preponderance over $T$ cells in the mucosal lymphoid tissue of the Peyer's patch parallels the preferential homing of $B$ lymphocytes in these tissues. For lymph nodes a comparable relation between distribution and homing preference is found, but here in favor of $T$ cells. Apparently lymphocyte traffic from the blood into the various lymphoid tissues is not a random process, but exhibits organ specificity, most likely related to specific immune functions of a particular lymphoid organ (5-9). The homing of blood lymphocytes to lymphoid tissues (spleen excepted) is controlled by organ-specific cell adhesion molecules (addressins) on high endothelial venules (HEV) and receptor adhesion molecules (homing receptors) expressed by migrating lymphocytes (5, 10-12).

The binding capacity of lymphocytes to HEV has been demonstrated to be directly related to the actual process of extravasation and entrance of lymphocytes into the tissue (13). Which particular addressins or homing receptors are expressed by HEV and Iymphocytes, respectively, seems to be strictly controlled by local microenvironments in lymphoid organs (14). To define potential immune functions of oro-nasopharyngeal lymphoid tissue in the rat, we have studied: 1) the distribution of B and T lymphocytes, and helper and suppressor/ cytotoxic T cell subsets in the Waldeyer ring equivalent (WRE) lymphoid tissue; 2 ) the in vitro binding of lymphocyte subsets to HEV in frozen sections of WRE tissue, a parameter reflecting in vivo lymphocyte homing potentials. The data show that in the WRE tissue $\mathrm{B}$ cells predominate over $\mathrm{T}$ cells, and $\mathrm{T}$ helper cells (CD4) over $\mathrm{T}$ suppressor/cytotoxic cells (CD8). However, a reversed preference is noticed in the binding of $T$ versus $B$ cells to HEV (which is unique for WRE lymphoid tissue) and also of CD8 versus CD4 T cells. The data are discussed in the context of immunological significance of oro-nasopharyngeal lymphoid tissue.

\section{Materials and methods}

\section{Animals and Tissues}

Eight-week old male inbred Lewis rats were obtained from the Central Animal Facility of the University of Limburg. Animals were bred under SPF conditions and had free access to food 
and water. Lymphoid organs were removed after ether anaesthesia and exsanguination of the animals and kept on ice in buffer containing $2.5 \%$ fetal calf serum (FCS). The paired lymphoid organs in the first nasal choana were dissected after removing the palatum with scissors (4).

\section{Immunohistology}

WRE tissue was snap frozen in isopentane and stored at $-70^{\circ} \mathrm{C}$ until use. Frozen $6-8 \mu \mathrm{m}$ thick sections were cut; acetone-fixed for $10 \mathrm{~min}$, and air-dried for $30 \mathrm{~min}$ using a fan. Immunoperoxidase staining was carried out routinely as previously described (15). In brief; sections were incubated wh a first step mouse monoclonal antibody diluted in PBS (8.75 g/L $\mathrm{NaCl}, 1.41 \mathrm{~g} / \mathrm{L} \mathrm{Na} \mathrm{HPO}_{4} .2 \mathrm{H}_{2} \mathrm{O}, 0.21 \mathrm{~g} / \mathrm{L} \mathrm{KH}_{2} \mathrm{PO}_{4}$ ) containing $0.05 \%$ bovine serum albumin (BSA) for $60 \mathrm{~min}$ at room temperature. Sections were washed $3 \mathrm{x}$ in PBS for $10 \mathrm{~min}$. Second step incubation occurred for $30 \mathrm{~min}$ with peroxidase-conjugated rabbit anti-mouse Ig (DAKO, Glostrup, Denmark) in PBS with BSA, to which $5 \%$ normal rat serum was added. After $3 x$ washing in PBS, sections were incubated with $0.01 \%$ diaminobenzidine and $0.02 \%$ hydrogen peroxide in PBS for $10 \mathrm{~min}$. After washing, sections were lightly counterstained with hematoxylin, dehydrated, and cover slipped with Entallan (Merck, Darmstadt, Germany).

\section{Lymphoid Cell Suspensions}

Cell suspensions of lymphoid organs were prepared by teasing the tissue on a nylon gauze under frequent flushing with cold Kryrode buffer 【(modified Tyrode's salt solution (Gibco, Breda, The Netherlands), containing $1.95 \mathrm{~g} / \mathrm{L} \mathrm{NaH} \mathrm{PO}_{2} 2 \mathrm{H}_{2} \mathrm{O}, 0.11 \mathrm{~g} / \mathrm{L} \mathrm{CaCl}, 1 \%$ phenol red, and $2.5 \% \mathrm{FCS})]$. Suspensions with flushed cells were layered on top of a two step ( $80 \%$ and $30 \%$ ) Percoll (Pharmacia, Uppsala, Sweden) gradient and centrifuged ( $800 \mathrm{G}, 20 \mathrm{~min}$, room temperature) to remove dead cells and debris. Lymphoid cells were collected from the interphase, washed $3 \mathrm{x}$. and tested for viability by Trypan blue exclusion. Viability of suspensions used was $95 \%$ or more. Purified $\mathrm{T}$ cell populations were obtained by passaging lymphocyte suspensions over nylon wool according to Julius et al. (16).

\section{Fluorescent Flow Cytometry}

Lymphocyte suspensions were stained using a two-step immunofluorescence technique: $5.10^{5}$ $-10.10^{5}$ cells in $0.11 \mathrm{ml}$ were incubated with mouse monoclonal antibodies against lymphocyte subsets for $30 \mathrm{~min}$ at $4^{\circ} \mathrm{C}$. Antibodies were used at saturating concentrations. Subsequently the cells were washed 3 times in buffer containing $0.1 \% \mathrm{BSA}$ and incubated for 30 min with a second step fluorescinated goat $\mathrm{F}(\mathrm{ab}) 2$ anti-mouse antibody (F-P ratio 5.6 , absorbed with rat IgG; Organon Teknika, Boxtel, The Netherlands). After 3 washes, cells were fixed in $1 \%$ paraformaldehyde and analyzed by flow cytometry as described previously (17) using a FACS IV (Becton \& Dickinson, Mountain View, USA). Cell suspensions only incubated with second step antibody served as (negative) control. Because WRE tissue yielded only small numbers of lymphocytes, FACS analysis was performed on pooled suspensions from 5 animals. To allow proper comparison with FACS profiles of other lymphoid tissues, cell suspensions of these tissues were also from pooled organs of (the same) 5 animals. 


\section{Monoclonal Antibodies (mAb)}

The following mAbs were used for identification of lynphocyte subsets: W3/13 (T cells), W3/25 (CD4, Thelper cells), OX-8 (CD8, T cytotoxic/suppressor cells), all donated by Dr: A Williams (Oxford, England); MARK (anti kappa-light-chain), MARL (anti lambdalight-chain), all donated by Dr. H. Bazin (Leuven, Belgium); R 73 (T cell receptor alpha/beta), donated by Dr. T. Hünig (Münich, Germany).

\section{In vitro Lymphocyte Binding to High Endothelial Venules}

Lymphocyte binding to $\mathrm{HEV}$ in frozen sections of lymphoid tissue was carried out as described originally by Stamper \& Woodruff (18) with modifications according to Butcher and Ford (19). Briefly: Lymphocyte suspensions from mesenteric lymph node or WRE tissue were prepared as described above. Pooled cells from 5 animals were resuspended in cold RPMI (Flow, Irvine, England) containing $20 \mathrm{mM}$ Hepes and 10\% FCS. Suspensions were adjusted to $1.10^{\gamma}$ cells/ml. Frozen $12 \mu \mathrm{m}$ thick sections were freshly cut and mounted on glass slides with 2 wells of 15-mm diameter (Cell-Line Ass. Inc., Newfield, USA). Cell suspensions were passed over a nylon gauze before use to remove cell aggregates. $100 \mu 1$ of cell suspension was layered per well and rotated with $80 \mathrm{rpm}$ for $30 \mathrm{~min}$ at $7^{\circ} \mathrm{C}$. Next, nonbound cells were removed by carefully tilting the slides on a paper towel, and the sections with bound cells were fixed by incubation in $0.2 \%$ glutaraldehyde for 10 min followed by incubation in $1 \%$ paraformaldehyde for $30 \mathrm{~min}$. Then sections were carefully rinsed in PBS followed by immuno-fluorescent staining using lymphocyte subset-specific monoclonal antibodies. For determining $T$ versus $B$ cell binding to $\mathrm{HEV}, \mathrm{mAb}$ W3/13 was added to the cell suspension during the rotation step to label $T$ cells. For determining $T s / c$ (CD8) versus Th (CD4) cell binding, purified $T$ cell suspensions (see above) were used and incubated during rotation with $\mathrm{OX}-8$. After the fixation step, sections were incubated with a second step fluorescinated anti-mouse antibody for $30 \mathrm{~min}$ (see flow cytometry). Labeled and unlabeled cells bound to HEV were counted under a Zeiss fluorescence microscope, and used to calculate $\mathrm{T} / \mathrm{B}$ or $\mathrm{CD} 8 / \mathrm{CD} 4$ binding ratios. Initial studies showed that none of the antibodies used was interfering with capacities of lymphocytes to bind to HEV, that calculated T-B binding-ratios were similar from W3/13 or MARK stained suspensions, and that CD8-CD4 binding-ratios were similar from W3/25 or OX-8 stained T cell suspensions. Because W3/13 and OX-8 stained brighter, these antibodies were used in most of the experiments. For accurate quantitation of lymphocyte binding to HEV and comparison of WRE to other lymphoid organs, the tissue sections used for HEV binding studies were from pooled lymphoid organs from 5-7 rats. Per experiment multiple sections of individual lymphoid organs were used. In lymph nodes and WRE per experiment 150-300 bound cells were usually counted for each tissue. In PP which has less HEV and worse lymphocyte binding, 20-140 bound cells were counted per experiment. B-T and CD8-CD4 HEV-binding-ratios were calculated as follows: actual binding ratio $(\mathrm{Ra})=$ ratio of cells counted on $\mathrm{HEV}(\mathrm{Rc})$ divided by ratio of cells in input suspension ( $\mathrm{Ri}),-\mathrm{Ra}=\mathrm{Rc} / \mathrm{Ri}$ - For statistical calculations the Student's $t$-test was used. 


\section{Abbreviations}

BSA, bovine serum albumin; CLN, cervical lymph node; FACS, fluorescent activated cell sorting, FCS, fetal calf serum; HEV, high endothelial venule, MLN, mesenteric lymph node; PP, Peyer's patch; WRE, Waldeyer's ring equivalent.

\section{Results}

\section{In sifu Localization of Lymphocyte Subsets in WRE Tissue}

Sections of WRE tissue that had been stained in the immunoperoxidase technique with mAbs reactive with $T$ cells (W3/13), B cells (MARK), CD 4 T-cells (W3/25), and CD8 T-cells (OX-8), showed the presence of well organized $\mathrm{T}$ and $\mathrm{B}$ cell areas [Fig. $1(\mathrm{~A})$ and $(\mathrm{B})]$ ]. The $\mathrm{B}$ cell areas predominated, they contained germinal centers, and were aligning the side of the tissue facing the nasopharyngeal lumen. In the $T$ cell areas high endothelial venules were distinguished. CD4 cells outnumbered CD8 cells [Fig. 1 (C) and (D)].
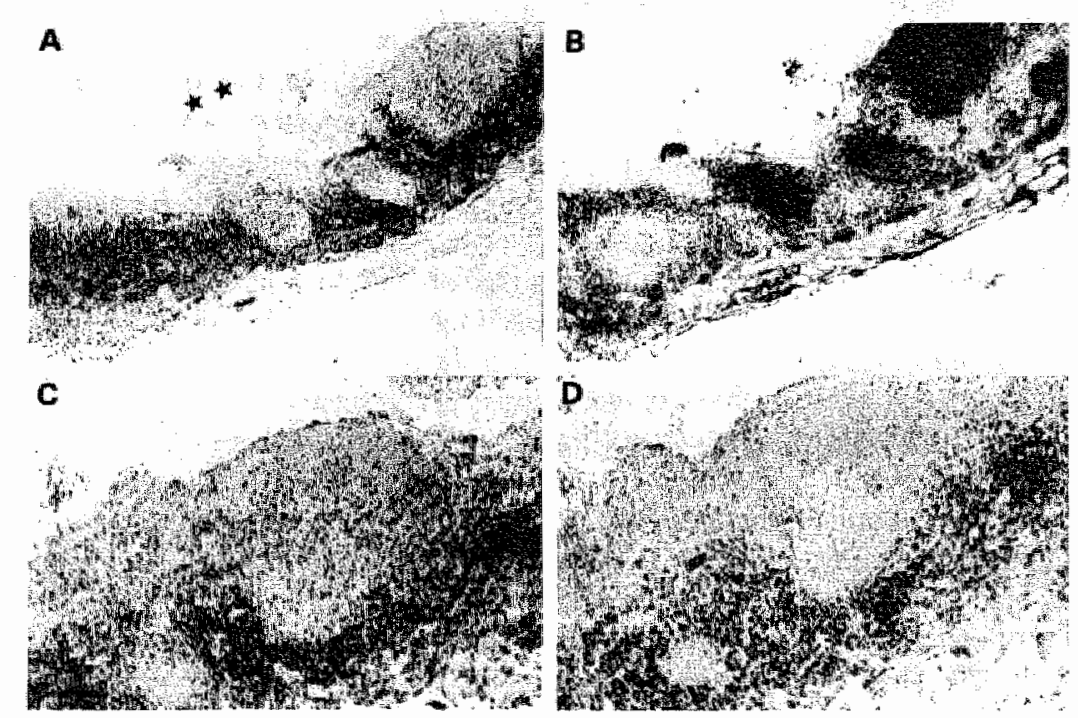

Figure 1. Lymphocyte subset distribution in WRE tissue. Immunoperoxidase staining (black). (A) W3/13 (pan-T cell) staining showing $T$ cell compartments predominantly located at the abluminal site of the WRE. Asterisk indicates the nasal lumen $(x 80)$.

(B) MARK (B cell) staining. Consecutive section. Notice B cell follicles are located subepithelial at the luminal side of the WRE ( 880 ).

(C) CD4 T-cell staining with W3/25. Notice the presenece of CD4 cells in the B cell follicles (x160).

(D) Consecutive section. CD8 T-cell staining with OX8. Notice $\mathrm{CD} 4$ cells (see C) outnumber CD8 cells in the $T$ cell compartment $(x 160)$. 


\section{Distribution of Lymphocyte Subsets in Cell Suspensions}

For quantitative analysis of lymphocyte subset distribution, lymphocyte cell suspensions of WRE tissue were studied by FACS analysis. The FACS profiles showed that B cells outnumbered $\mathrm{T}$ cells and that CD4 cells had a much higher frequency than CD8 T-cells (Table 1); these data are in accordance with the immunohistological observations. Most Tucells expressed the $\alpha / \beta$ T cell receptor (TCR) as demonstrated by simular distribution profiles (data not shown) obtained with W3/3 (pan-T cell) and R73 ( $\alpha / \beta$ TCR).

\begin{tabular}{|c|c|c|c|c|c|c|}
\hline \multirow[b]{2}{*}{ Tissue } & \multicolumn{4}{|c|}{ Membrane Positive Lymphocytes (\%) } & \multicolumn{2}{|c|}{ Ratio } \\
\hline & T Cells & B Cells & CD4 T-Cells & CD8 T-cells & $\mathrm{T}-\mathrm{B}$ & $\mathrm{CD} 8-\mathrm{CD} 4$ \\
\hline WRE & 36.0 & 53.7 & 26.9 & 5.3 & 0.7 & 0.20 \\
\hline CLN & 73.8 & 19.5 & 55.3 & 14.4 & 3.8 & 0.26 \\
\hline MLN & 76.1 & 21.1 & 54.7 & 12.9 & 3.6 & 0.24 \\
\hline PP & $\mathbb{1 1 . 9}$ & 63.9 & 11.3 & 1.7 & 0.2 & 0.15 \\
\hline Spleen & 51.2 & 30.0 & 38.7 & 15.5 & 1.7 & 0.40 \\
\hline $\begin{array}{l}\text { Data are f } \\
5 \text { rats wer } \\
\text { MARK + } \\
\text { cells). } \\
\text { Abbrewati } \\
\text { WRE, Wa }\end{array}$ & $\begin{array}{l}\text { om a repre } \\
\text { used for } \mathrm{f} \\
\text { MARL (B } \\
\text { ons: CLN, } \\
\text { Ideyer's rin }\end{array}$ & $\begin{array}{l}\text { sentative ex } \\
\text { uorescent f } \\
\text { ells), W } 3 / 2 \\
\text { ervical lym } \\
\text { equivalen }\end{array}$ & $\begin{array}{l}\text { perimemt in which } \\
\text { ow cytometrical a } \\
5 \text { (CD } 4 \text {, T helper } \\
\text { ph node; MLN, m }\end{array}$ & $\begin{array}{l}\text { suspensions of } \\
\text { halysis. Antibod } \\
\text { ells), OX-8 (CD } \\
\text { senteric lymph }\end{array}$ & $\begin{array}{l}\text { ed lym } \\
\text { used: R } \\
\text { suppre } \\
\text { e:PP, P }\end{array}$ & $\begin{array}{l}\text { hoid organs fr } \\
73 \text { (T cells) } \\
\text { ssor/cytotoxic } \\
\text { eyer's patch; }\end{array}$ \\
\hline
\end{tabular}

Table I. Distribution Profiles of Lymphocyte Subsets in WRE and Other Lymphoid Tissues.

The lymphocyte subset profiles and calculated T-B and CD4-CD8 cell ratios from WRE lymphocytes were compared to those of other lymphoid organs from the same series of: animals. The T-B and CD4-CD8 subset ratios of WRE tissue were quite distinct from those obtained from peripheral and mesenteric lymph node, from Peyer's patch, and spleen. WRE lymphocyte subset ratios closest resembled those obtained in Peyer's patch mucosal lymphoid tissue (Table 1). 


\section{In vitro Lymphocyte Binding to $\mathrm{HEV}$}

Tissue lymphocyte profiles are the result of lymphocyte immigration local retention and proliferation. Because lymphocyte migration in lymphoid tissues is mainly from the blood and mediated via HEV, we wished to determine how well, and in which ratio the various lymphocyte subsets bind to HEV of the WRE Iymphoid tissue. The previously described frozen section assay was ised to study lymphocyte binding to HEV. To define how well the HEV in WRE tissue boutd lymphocytes in relation to HEV of other lymphoid organs, suspensions of total mesenteric lymph node cells were used to study HEV binding in vitro. The amount of WRE tissue that can be collected per rat did not allow binding studies in individual animals. For reliable comparison of lymphocyte binding to HEV between the various lymphoid organs, WRE tissues and also the other lymphoid tissues used for HEV binding studies, were pooled from 5 to 7 animals. Table 2 shows the number of lymphocytes bound per HEV of WRE, cervical and mesentenc lymph node, and Peyer's patch tissue.

\begin{tabular}{|l|l|r|r|}
\hline HEV Tissue & Lymphocytes & $\begin{array}{c}\text { Numbers of } \\
\text { Counted HEV }\end{array}$ & $\begin{array}{c}\text { Lymphocytes Bound/HEV } \\
\text { (mean } \pm \text { standard deviation) }\end{array}$ \\
\hline CLN & MLN (T+B) & $106(2)$ & $11.9 \pm 8.6$ \\
MLN & MLN (T+B) & $29(1)$ & $11.7 \pm 5.9$ \\
WRE & MLN (T+B) & $197(3)$ & $9.6 \pm 5.4^{\circ}$ \\
PP & MLN (T+B) & $44(2)$ & $3.5 \pm 2.0$ \\
\hline CLN & MLN T cells & $106(4)$ & $10.5 \pm 5.8$ \\
MLN & MLN T cells & $50(2)$ & $7.4 \pm 3.5$ \\
WRE & MLN T cells & $91(3)$ & $6.4 \pm 3.1^{\mathrm{c}}$ \\
PP & MLN T cells & $20(1)$ & $4.3 \pm 2.3$ \\
\hline CLN & WRE T cells & $89(3)$ & $10.2 \pm 6.6$ \\
MLN & WRE T cells & $70(3)$ & $5.9 \pm 3.5$ \\
WRE & WRE T cells & $106(3)$ & $6.3 \pm 3.1^{\mathrm{c}}$ \\
PP & WRE T cells & $20(2)$ & $2.9 \pm 1.2$ \\
\hline
\end{tabular}

Data from in vitro binding assay.

CLN, cervical lymph node; MLN, mesenteric lymph node; PP, Peyer's patch; WRE, Waldeyer's ring equivalent lymphoid tissue.

- Pooled from 5 animals

b Between bars are the numbers of experiments used for counting HEV

c WRE differs significantly from PP and CLN ( $p<0.01$ )

Table 2. Capacity of High Endotheliall Venules (HEV) to Bind Lymphocytes. 
The results show that HEV in WRE lymphoid tissue bound lymphocytes almost as good as mesenteric and cervical lymph node HEV. Lymphocyte binding to HEV in WRE was significantly higher than binding to Peyer's patch HEV. Next we tested how well T cells bound to HEV in the various lymphoid tissues. In these studies T cells were used obtained from MLN suspensions by depletion for $B$ cells wia nylon wool passage. Table 2 shows that $T$ cells bound best to HEV in CLN, followed by MLN and WRE. The poorest binding of $T$ cells was observed for HEV in PP. Preferential binding of lymphocyte subsets to HEV in WRE tissue was studied for $\mathrm{B}$ versus $\mathrm{T}$ cells and $\mathrm{CD} 4$ versus $\mathrm{CD} 8 \mathrm{~T}$-cells. Mesenteric lymph node cells were allowed to bind to HEV in sections of WRE, MLN, and CLN, and PP. Sections with bound lymphocytes were fixed and stained with $\mathrm{mAb}$ W3/13 to detect $\mathrm{T}$ cells. $\mathrm{T}-\mathrm{B}$ ratios were calculated from the numbers of positive (T) and negative (B) cells bound to $\mathrm{HEV}$. That in fact, negative cells were $B$ cells was confirmed by experiments in which $T-B$ ratios calculated from sections stained for either $T$ cells (W3/13) or B cells (MARK) gave similar results (data not shown). In addition, when the input suspensions were stained for both $\mathrm{T}$ and B cells, a total of almost $100 \%$ stained cells was obtained, showing the near absence of cells other than $T$ or $B$ cells. As shown in Fig. 2, T cells adhere better than $B$ cells to HEV in the WRE lymphoid tissue (T-B ratio 1.8). The T-B ratio closely resembles the ratio found for mesenteric lymph node. Individual experiments showed slight differences for WRE and MLN, but the average $\mathrm{T}-\mathrm{B}$ cell binding ratios for both organs were similar. The T-B ratio for WRE tissue was distinct from CLN and PP. CLN had a higher ratio and PP had a much lower ratio. Surprisingly, the WRE tissue showed a contrast between the T/B cell binding preference to HEV and the distribution of $T$ and $B$ cells in situ. None of the other tested lymphoid organs showed this. To study CD4 versus CD8 T-cell binding to HEV in WRE tissue, MLN T cells were used. CD8 cells that were bound to HEV in WRE. CLN, and MLN were identified by fluorescent staining with $\mathrm{MAb} O \mathrm{OX}-8$, negative cells were considered CD4 cells.

T/B-Binding to HEV in Lymphold Tisisue

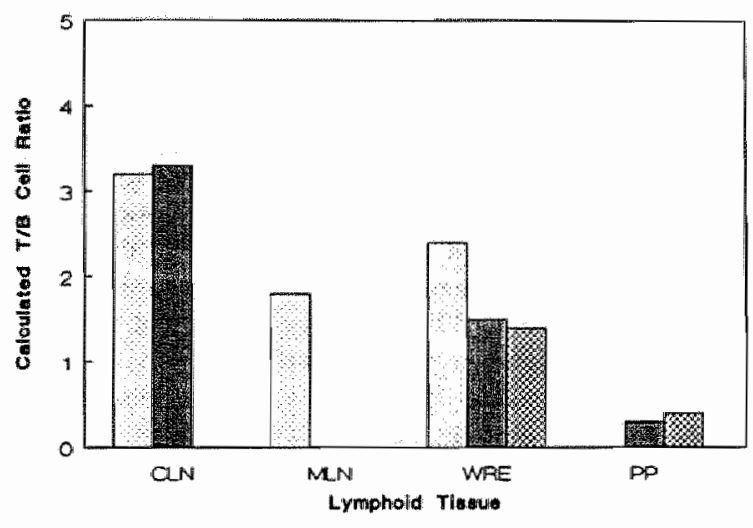

Figure 2. T-B binding ratios to HEV were studied in threes experiments (each type of shading represents an individual experiment). Lymphocytes used for binding to HEV were Percollpurified MLN lymphocytes. Lymphocytes and tissuc sections were pooled from lymploidl organs form 5-7 rats. For technical information see Materials and Methods section. CLN, cervical lymph node; MLN, mesenteric lymph node, PP, Peyer's patch; WRE, Waldeyer's ring equivalent. 
As shown in Figure 3, CD8 cells bound far better than CD4 cells to the HEV in all lymphoid tissues except for the PP in which CD8 T-cells bound equally well as CD4 cells. The highest binding ratio (CD8/CD4 $=3.2$ ) was found for HEV in the WRE lymphoid tissue. The HEVbindling ratios of $C D 8$ cells over CD4 cells are distinct from their in situ distribution profiles in the lymphoid organs. In fact, CD8-CD4 binding ratios are almost opposite to in situ distribution ratios in WRE, CLN, and MLN.

Although it has been reported that the binding capacities of $T$ lymphocytes to HEV is independent of the cell source (7), we compared the HEV binding data of MLN T cells with those of T cells from WRE. Nylon wool purified WRE T cells were tested for binding to HEV in various lymphoid tissues. WRE $T$ cells showed binding preference almost comparable to MLN T cells, e.g., CLN > MLN and WRE > PP (Table 2) Figure 3 shows that the CD8-CD4 binding ratios of WRE cells to HEV of CLN, WRE, and PP were quite similar to those of MLN T cells. Only for HEV of MLN was the CD8 - CD4 ratio lower with WRE cells than with MLN cells.

\section{Ta/Th-Binding to HEV in Lymphoild Tiesuse}

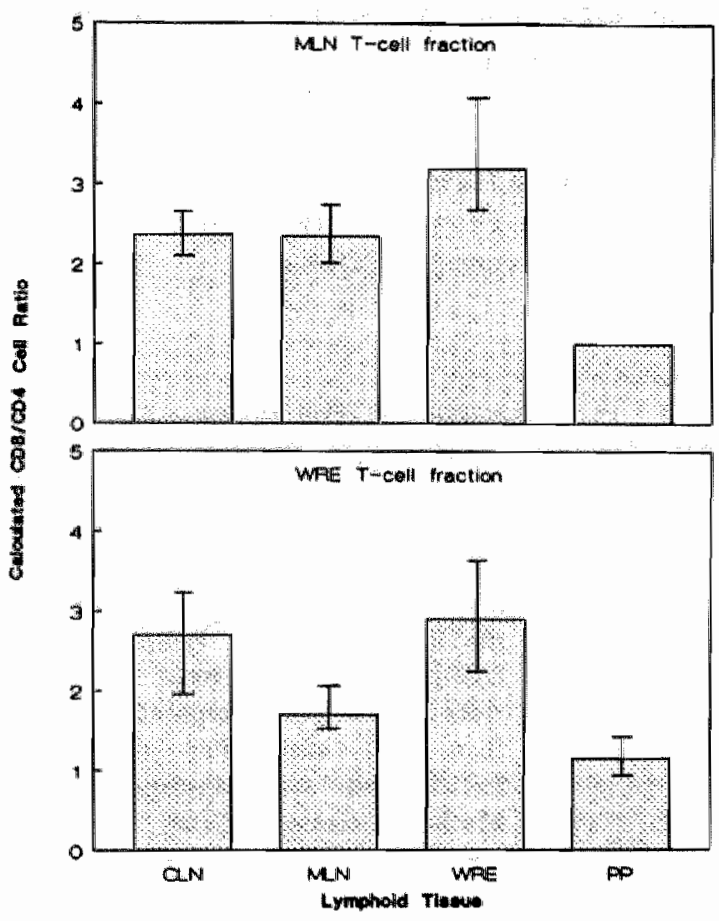

Figare 3. Columns represent the mean CD8-CD4 HEV-binding ratio for the various lymphoid tissues. Bars indicated ration ranges of 2 or more experiments. Upper panel shows data obtained with MLN T cells (PP was 1 experiment). Lower panel shows data from WRE $T$ cells. Cells and tissues were pooled from 5-7 rats. CLN, cervical lymph node, MLN, mesenteric lymph node, PP, Peyer's patch; WRE, Waldeyer"s ring equivalent. 
Table 3 summarizes the series of HEV binding data obtained with MLN and WRE cells

\begin{tabular}{|c|c|c|c|c|c|c|c|c|c|}
\hline \multirow[b]{3}{*}{ Exp. } & \multirow[b]{3}{*}{ Cell Source ${ }^{*}$} & \multicolumn{4}{|c|}{ T-B Binding ratio } & \multicolumn{4}{|c|}{ CD8-CD4 Binding ratio } \\
\hline & & \multicolumn{4}{|c|}{ Tissue $^{a}$} & \multicolumn{4}{|c|}{ Tissue } \\
\hline & & WRE & CLN & MLN & $\mathrm{PP}$ & WRE & CLN & MLN & Pp \\
\hline $\begin{array}{l}1 \\
2 \\
3 \\
1+2+3 \\
4 \\
5 \\
6 \\
7 \\
4+5+6+7 \\
8 \\
9 \\
10 \\
8+9+10 \\
4+5+6+7+ \\
8+9+10\end{array}$ & $\begin{array}{l}\text { MLN } \\
\text { MLN } \\
\text { MLN } \\
\text { MLN } \\
\text { MLN } \\
\text { MLN } \\
\text { MLN } \\
\text { MLN } \\
\text { MLN } \\
\text { WRE } \\
\text { WRE } \\
\text { WRE } \\
\text { WRE } \\
\text { WRE/MLN }\end{array}$ & $\begin{array}{l}2.4 \\
1.5 \\
1.4 \\
1.8 \\
- \\
- \\
- \\
- \\
- \\
- \\
- \\
- \\
- \\
-\end{array}$ & $\begin{array}{l}3.2 \\
3.3 \\
- \\
3.2 \\
- \\
- \\
- \\
- \\
- \\
- \\
- \\
- \\
- \\
-\end{array}$ & $\begin{array}{l}1.8 \\
- \\
- \\
1.8 \\
- \\
- \\
- \\
- \\
- \\
- \\
- \\
- \\
-\end{array}$ & $\begin{array}{l}- \\
0.3 \\
0.4 \\
0.4 \\
- \\
- \\
- \\
- \\
- \\
- \\
- \\
- \\
-\end{array}$ & $\begin{array}{l}- \\
- \\
- \\
- \\
- \\
2.9 \\
2.6 \\
4.1 \\
3.2 \\
3.7 \\
2.9 \\
2.2 \\
2.9 \\
3.0\end{array}$ & $\begin{array}{l}- \\
- \\
- \\
2.1 \\
2.4 \\
2.4 \\
2.6 \\
2.4 \\
1.9 \\
3.3 \\
3.1 \\
2.7 \\
2.6\end{array}$ & $\begin{array}{l}- \\
- \\
- \\
- \\
- \\
- \\
2.0 \\
2.7 \\
2.4 \\
1.6 \\
1.5 \\
1.0 \\
1.7 \\
2.0\end{array}$ & $\begin{array}{l}- \\
- \\
- \\
- \\
- \\
- \\
- \\
1.0 \\
1.0 \\
- \\
1.5 \\
0.8 \\
1.2 \\
1.1\end{array}$ \\
\hline
\end{tabular}

Table 3. Lymphocyte Subset Binding to HEV in Lymphoid Tissue.

\section{Discussion}

We have studied the oro-nasopharyngeal lymphoid tissue, determined as Waldeyer's ring equivalent (WRE), in the rat. Distribution of lymphocyte subsets in WRE tissue was analyzed using organ sections and cell suspensions. Sections stained with mAbs recognizing $\mathrm{B}$, $\mathrm{T}$, and $T$ helper (CD4) and T cytotoxic/suppressor (CD8) lymphocytes showed the various lymphocyte subsets to be compartmentalized on a similar way as in other lymphoid tissues such as lymph nodes and Peyer' $\mathrm{s}$ patches. $\mathrm{B}$ cell areas predominated over " $\mathrm{T}$ cell areas, and in the $\mathrm{T}$ 
the Till areas CD4 cells were preponderant ower CD8 T-cells. These results were confirmed and precisely quantified by FACS analysis of WRE lymphocyte suspensions. The T-B ratio of 0.7 in WRE tissue in favor of $B$ cells resembles the PP. CLN, MLN, and spleen all had T-B ratios $>1$. Also for the nasopharyngeal tonsillar lymphoid tissue in man it has been shown that $B$ cells predominate over $T$ cells (20). The results of the CD4 and CD8 T-cell distribution in the WRE tissue closest resembles the distribution in the PP.

Although all lymphoid tissues show a preponderance of CD4 over CD8 cells, WRE and PP have considerably higher CD4CD8 ratios compared to other lymphoid organs. In general, the lymphocyte-subset distribution data show that the WRE tissue resembles the PP, and as such, this nasopharyngeal lymphoid tissue is clearly distinct from spleen and lymph nodes.

Information on lymphocyte traffic to the WRE from the blood was achieved by using the in vitro assay in which small MLN lymphocytes (less than $1.5 \%$ blasts, data not shown) were allowed to bind to HEV in frozen tissue sections. Previous studies have demonstrated that the binding of lymphocytes to $\mathrm{HEV}$ is a reliable parameter for lymphocyte immigration into lymphoid tissues in vivo (21). The results obtained on the capacity of HEV to bind lymphocytes, show that HEV in the WRE bind lymphocytes almost equally well as HEV in mesenteric and cervical Jymph nodes. Lymphocyte binding to HEV in WRE was about 3 times higher than binding to HEV in PP. In this respect WRE is clearly different from PP. This, together with the relatively high numbers of HEV that were found in WRE tissue sections in comparison to PP sections (data not shown), suggests that on a tissue volume base the WRE may have a much higher rate of lymphocyte entrance from the blood than the PP. Apparently, in the recirculation process of small lymphocytes, WRE tissue has almost the same capacities to recruit $\|$ ymphocytes from the blood as lymph nodes have, and as such the immunosurveillance potentials of nasopharyngeal lymphoid tissue can be considered significant. In previous lymphocyte migration studies in wivo we found that $24 \mathrm{~h}$ after intravenous injection of radio-labeled lymphocytes the highest numbers of counts per gram of lymphoid tissue (containing $\mathrm{HEV}$ ) were found in the $\mathrm{LN}$, followed by the WRE and finally the PP (4). However, a twofold difference between $\mathrm{LN}$ and WRE was measured, which is considerably more than expected from the almost equal numbers of lymphocytes binding to HEV in WRE and LN in vitro. In contrast, the difference between WRE and PP (WRE had about $1.2 \times$ more counts per gram) was smaller than expected from the in witro data. Apparently, the in viro binding capacities of lymphocytes to $\mathrm{HEV}$ are not similar to $24 \mathrm{~h}$ distribution of lymphocytes in vivo. This shows that adherence to HEV indeed is not the only parameter defining in vivo distribution of lymphocytes in lymphoid organs. Westermann et al. (22) showed that already a few hours after injection of lymphocytes, they show up in the thoracic duct lymphdrainage. They demonstrated a differential appearance of lymphocyte subsets in the draining lymph (see below). In fact, these data indicate that the capacity of Jymphocytes to bind to HEV may reflect the rate of lymphocyte entrance into lymphoid tissue, but not the kinetics of lymphocyte recirculation. The localization of recirculating lymphocytes in long term migration experiments is apparently also controlled by local mechanisms of Jymphocyte retention in the lymphoid tissues.

The results of lymphocyte subset binding to HEV in frozen sections showed that $\mathrm{T}$ cells bind better than $B$ cells to HEV in WRE. This was a quite remarkable finding, making the WRE 
the only lymphoid tissue in which the T-B binding ratio to HEV contrasts to the T-B distribution ratio in situ. In all other lymphoid organs tested, e.g. CLN, MLN, and PP, the HEV-binding preference of T over B cells (PP) or vice versa (CLN and MLN) corresponds to the in siru T or B cell preference. In the WRE local cell death and proliferation (parameters that may influence distribution profiles in lymphoid organs) were not different from the other lymphoid tissues (data not shown). Therefore, the preponderance of B over T cells in situ may be the result of a relatively quick passage/short local retention of T cellis in the WRE in comparison to $\mathrm{B}$ cells. Interestingly, in man a reversed $\mathrm{T}-\mathrm{B}$ ratio with respect to binding to HEV and in situ distribution has also been demonstrated exclusively for tonsillar lymphoid tissue (23). Westermann et al. (22) described that after injection of lymphocytes in rats, T cells appear in the thoracic duct lymph earlier than B cells. Apparently, T cells leave the (lymphoid) organs much quicker than B cells. It remains to be investigated by which local mechanisms a superior adhesion of T cells over B cells to HEV in the WRE leads to an in situ preponderance of $B$ over $T$ cells. Although differential retention mechanisms for $T$ and $B$ cells in the WRE may play an important role in this respect, it cannot be excluded that binding ratios of $T$ and $B$ cells to HEV do not reflect actual immigration (extravasation), It may be that bound $\mathrm{B}$ cells to HEV in WRE tissue in vivo have a much higher transmigration rate than bound $T$ cells. We have initiated short term loming experiments to study passaging of $T$ cells through the WRE versus other lymphoid organs. Preliminary results ( 3 animals) show that upon injection of radiolabeled cells in vivo, the percentage of accumulation of cells (counts per minute) per gram of tissue from 2 to $24 \mathrm{~h}$ is about $15 \%$ less for WRE than for MLN, which has a similar T-B binding ratio to HEV as WRE tissue. These data are in support of a more rapid passage of cells through the WRE than through the MLN.

Further experiments will allow more definite conclusions. A similar discrepancy between HEV-binding and in vivo distribution is seen for $\mathrm{CD} 8(\mathrm{Ts} / \mathrm{c})$ and $\mathrm{CD} 4(\mathrm{Th})$ cells in the various lymphoid tissues, including WRE. CD8 cells. regardless of whether they were from MLN or WRE origin, bound better than CD4 cells to the HEV in lymphoid organs (except for PP, in which a 1 to 1 binding ratio was found), whereas in the tissue distribution profiles CD4 cells were seen to outnumber $\mathrm{CD} 8 \mathrm{~T}$-cells. Whether a high $\mathrm{CD} 8-\mathrm{CD} 4$ binding ratio to HEV reflects CD8-CD4 immigration ratios in vivo remains to be elucidated. Jeurissen et al. (24) showed that in the T cell population drained from the PP, CD8 cells dominate. It has been suggested that the high migration of CD8 cells through mucosal tissues such as PP and tonsils may be of importance for the regulation of immune suppression/tolerance to mucosal antigens (23-25). We found the highest $\mathrm{CD} 8$ versus CD4 cell binding to HEV in WRE. Whether this is related to a particular regulatory role of $\mathrm{CD} 8$ cells in oro-nasopharyngeal lymphoid tissue for immune suppression to air and/or food way antigens remains to be elucidated. A cytotoxic function of the CD8 population is a possibility to be kept in mind also, especially because nasal application of infectious viral and also bacterial antigens has been demonstrated to induce immune response against these agents (26). 


\section{In conclusion:}

The Waldeyer ring equivalent nasopharyngeal lymphoid tissue in the rat can be considered a first line mucosal lymphoid tissue responding to air and maybe also food antigens. B cells are preponderant over T' cells in the WRE in situ. However, the preference of T cells over B cells in binding to HEV nay reflect a strong dominance of $\mathrm{T}$ cells in the pool of lymphocytes immigrating the WRE. This suggests an important role for $T$ cells in this organ. What precise function these $T$ cells execute awaits further investigation.

\section{Acknowledgements}

The authors thanks Dr. F.I.C.R.S. de Jong for critically reading the manuscript. Dr. B. Schutte for FACS anallysis and F. Teng-Vangrootloon for secretarial support. 


\section{References}

1. de Jong FICRS, van Breda Vriesman PJC: Basic mechanisms of the nasopharyngeal immune system. Clin Otolaryngol 1985; 10:228.

2. Hameleers DMH, van der Ende M, Biewenga J. Sminia T: An immunohistochemical study on the postnatal development of rat nasal-associated lymphoid tissue (NAL.T). Cell Tissue Res 1989;256: $431-438$.

3. Spit BJ, Hendriksen EGJ, Bruijntjes JP, Kuper CF: Nasal lymphoid tissue in the rat. Cell Tissue Res 1989; 255: 431-438.

4. Koornstra PJ, de Jong FICRS, Vlek LFM, Marres EHMA, van Breda Vriesman PJC: The Waldeyer Ring Equivalent in the Rat. Acta Otolaryngol (Stockh) 1991; 11: $591-599$.

5. Duijvestijn A, Hamman A: Mechanisms and regulation of lymphocyte migration. Immunol Today $1989 ; 10: 23-28$.

6. Butcher EC: The regulation of lymphocyte traffic. Curr Top Microbiol Immunol 1986; 128: 85122.

7. Stevens SK, Weismann IL, Butcher EC: Differences in the migration of B and Tymphocytes: organ-selective localization in wivo and the role of lymphocyte-endothelial cell recognition. I Immunol 1982; 128: 844-851.

8. Kraal $\mathrm{G}$, Weissmann $\mathbb{L}$, Butcher EC: Differences in in vivo distribution and homing of $\mathrm{T}$ cell subsets to mucosal vs nonmucosal lymphoid organs. J Immunol 1983; 130: 1097-1102.

9. Abernethy NI, Hay JB, Kimpton WG, Washington $E_{4}$ Cahill RNP. Lymphocyte subset-specific and tissue specific lymphocyte-endothelial cell recognition mechanisms independently direct the recirculation of lymphocytes from blood to lymph in sheep. Immunology 1991; 72: 239. 245.

10. Berg EL, Goldstein LA, Jutila MA, Nakache M, Picker LJ, Streeter PR, Wu NW, Zhon D, Butcher $\mathbb{E C}$ : Homing receptors and vascular addressins: cell adhesion molecules that direct Jymphocyte traffic. Immunol Rev 1989; 108: 5-18.

11. Streeter PR, Lakey-Berg E, Rouse BTN, Bargatze RF, Butcher EC: A tissue specific endothelial cell molecule inwolved in lymphocyte homing. Nature 1988; 331:41-46.

12. Streeter PR, Rouse BTN, Butcher EC: Immunohistologic and functional characterization of a vascular addressin involved in lymphocyte homing into peripheral lymph nodes. I Cell Biol 1988; 107: 1853-1862.

13. Butcher EC, Scollay RG, Weissmann IL: Lymphocyte adherence to high endothelial venules: characterization of a modified in vitro assay, and examination of the binding of syngeneic and allogeneic lymphocyte populations. J Immunol 1979; 123:1996-2003. 
14. Mebius RE, Streeter PR, Breve J, Kraal G: The microenvironment of the lymph node and the expression of vascular addressins, in Imhof BA, Berrih-Aknin $S_{3}$. Enzine $S$ (eds), Lymphatic Tissues and In Vivo Immune Responses, New York, Marcel Dekker 1991; 895-899.

15. Duijvestijn AM, Kerkhove $M$, Bargatze RF, Butcher EC: Lymphoid tissue- and in inflammation-specific endathelial cell differentiation defined by monoclonal antibodies. $J$ Inmunol 1987; 138: 713-719.

16. Julius $\mathrm{MH}$, Simpson $\mathrm{E}$, Herzenberg LA: A rapid method for the isolation of functional thymus derived murine lymphocytes. Eur J Immunol 1973; 3: 645.

17. Nagelkerken LM, Schutte B, Stet RJM, van Breda Vriesman PJC: Recognition of rat dendritic cells by a monocional antibody. Scand J Immunol 1987; 26: 347-353.

18. Stamper HB, Woodruff JJ: Lymphocyte homing into lymphnodes: in virro demonstration of the selective affinity of recirculating lymphocytes for high endothelial venules. J Exp Med 1976; 144: $828-833$.

19. Butcher EC, Ford WL: Following cellular traffic: methods of labeling lymphocytes and other cells to trace their migration in vivo, in Weir D, Herzenberg LA (eds), Handbook of Experimental Immunology, 4th ed., Palo Alto, CA Blackwell 1984; 57.

20. Plum J, van Cauwenberghe $P$, De Smedt M: Phenotyping of mononuclear cells from tonsils and corresponding biopsies using a cytofluormeter. Acta Otolaryngol 1986; 101: 129-134.

21. Butcher EC, Scollay RG, Weissman IL: Organ specificity of lymphocyte migration: mediation by highly selective lymphocyte interaction with organ-specific determinants on high endothelial venules. Eur J Immunol 1980; 10: 556-561.

22. Westermann $J$, Puskas Z, Pabst R: Blood transit and recirculation kinetics of lymphocyte subsets in normal rats. Scand J Immunol 1988; 28: 203-210.

23. Pals ST, Kraal G, Horst E, de Groot A, Scheper RJ, Meijer CJLM: Hunan lymphocyte-high endothelial venule interaction: organ-selective binding of $T$ and $B$ lymphocyte populations to high endothelium. J Immunol 1986; 137: 760-763.

24. Jeurissen SHM, Sminia T, Kraal G: Selective emigration of suppressor T cells from Peyer's patches. Cell Immunol 1984; $35: 264$.

25. Mattingly JA, Waksman BH: Immunologic suppression after oral administration of antigen. I. Specific suppressor cells formed in rat Peyer's patches after oral administration of sheep erythrocytes and their systemic migration. J Immunol 1978; 121:1878.

26. Ivanoff $\mathrm{B}$, Fontagnes $\mathrm{AC}$, Jourdan $\mathrm{G}$ : Secondary inmune response to oral and nasal rough mutant strains of Salmonella typhimurium. Ann Immunol (Inst. Pasteur) 1982; 133D: 61-70. 


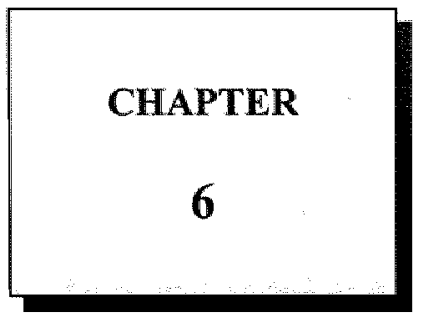

EPILOGUE 


\section{Epilogue}

In man the pharyngeal tonsil (adenoid), the palatine tonsils, the lingual tonsil, tonsillar structures around the openings of the two Eustachian tubes and scattered lymphoid tissue in the submucosa of the posterior pharyngeal wall jointly constitute "Waldeyer's Ring" (WR). In the rat such tonsillar structures are not found in the oronasopharynx, but mucosa associated rod-shaped lymphoid organs are located bilaterally in the nasopharyngeal duct near the first choana (1) and can be considered to be related functionally to the tonsillar organs in the human WR. Particularly on account of their location in the respiratory route and of the fact that they are being covered by respiratory tract-like (pseudo stratified and ciliated) epithelium, these lymphoid organs in the nose of the rat resemble most the pharyngeal tonsillar tissue in the WR. As such the rat nosel associated lymphoid tissue or NALT can be considered an experimental model for studying immune functioning of hamely upper respiratory tract aligning mucosa associated lymphoid tissue such as the pharyngeal tonsil in the nasopharynx in man.

\section{Clinical aspects of adenotonsillar tissues}

Although in man the WR is already present at birth, diseases of the pharyngeal and palatine tonsils are encountered mostly from the age of approximately six months. This may result from a decrease in maternal (antibody) immunity, initially present in the child. It may also reflect a change in diet, a change in environmental circumstances (e.g. exposure to infective agents at day care centers) or a combination of multiple causative factors. Especially in cases of chronically infected tonsils and in disease states where airway obstruction is caused by hypertrophic tonsils, adenotonsillectomy is applied as a therapy of first choice (2). In general the direct effects of such an operation are beneficial. Nonetheless a point of debate is whether the loss of these organs introduces a partial immunodeficiency or immune modulation that in time may lead to a state of immune deviation and disease. Clinical information suggests that adenotonsillectomy is related to increased susceptibility to infectious diseases such as poliomyelitis, and may predispose individuals to development of allergic and lymphoproliferative disorders. The evidence in support of such a relation between adenotonsillectomy and disease is in many cases rather circumstantial. However, it has been demonstrated convincingly that adenotonsillectomy leads to a lower immune status, especially with regard to IgA production in mucosal immunity $(3,4)$. Apparently, tonsillar tissues play an important role in the induction and maintenance of normal levels of IgA and particularly secretory IgA. This implies that from an immunological point of view adenotonsillectomy is not without risks and that particularly in young children the patients IgA status is an important factor in the consideration for tonsillectomy. Another clinical and immunological phenomenon in which adenotonsillar tissues are involved, concerns the category of allergic diseases in the nose and oro-nasopharyngeal region (5). Which role these tissues play in such allergic or hypersensitivity reactions and whether these reactions are enhanced or luxated by adenotonsillectomy is not clear so far. In general it can be stated that many of the clinically relevant questions about the immunological function of adenotonsillar tissues still await answering. 


\section{Immunological aspects of nasal and nasopharyngeal lymphoid tissues}

So far, we know that nasal and nasopharyngeal (adenotonsillar) tissues align the mucosal epithelium of the respiratory and alimentary tract. These organs contain all the various immunological cell types relevant for the initiation and propagation of an immune response, e.g., macrophages, antigen presenting cells, and T and B lymphocytes. As in all other mucosa associated lymphoid organs (e.g. Peyer's patches, BALT), and non-mucosal lymphoid organs/tissues (e.g. peripheral lymph nodes and the white pulp areas in the spleen), $\mathrm{T}$ and $\mathrm{B}$ cells are organized in different compartments. In these compartments specific antigen presenting cells (APC) are present. In the T cell compartment these APC are MHC class II positive dendritic cells (DC), whereas in the $\mathrm{B}$ cell compartment the most relevant APC are the follicular dendritic cells (FDC) located in the B cell follicles $(6,7)$. The antigen entrance route for the nasal and nasopharyngeal lymphoid tissues appears to be similar to the route followed in the gut associated lymphoid tissues, namely through specialized epithelial cells, so-called $M$ cells. These $M$ cells are essential for bringing particulate antigens, such as bacteria and viruses, to the underlying lymphoid tissue. It has been shown that $M$ cells actively take up particulate antigen and, by a process called transcytosis, deliver it to antigen presenting cells for further handling (reviewed in 8). Thus, the anatomical location of nasal and nasopharyngeal lymphoid tissues in combination with an extended tonsillar crypt surface to assure antigentrapping, and the presence of antigen-transporting $M$ cells, enable the individual to adequately monitor environmental antigen exposure, and to promptly initiate an immune response against it.

A crucial part in mounting an effective immune response towards antigen is the activation and proliferation of antigen-specific $T$ helper (CD4) cells. These $T$ helper cells are required for help to B cells and cytotoxic Tn cells. The process of antigen presentation to $T$ helper cells can be considered as a two step procedure. The first step is the recognition by the $T$ cell antigen receptor (TCR) of the antigen peptide exposed in the groove of the MHC class II molecules on the APC. This antigen-specific recognition step is alone not sufficient to trigger T-helper cell activation. The second step is necessary for activation, i.e. a co-stimulatory signal from the $A P C$. This signal is delivered upon interaction of $T$ cell molecules such as CD28 and CD40-ligand with the counterpart structures B7-1/ B7-2 and CD40 respectively on the $\mathrm{APC}$ (9). Interestingly, if this interaction is inadequate, for example by the absence of $\mathrm{B} 7$ molecules on the $\mathrm{APC}$, the interaction introduces a state of non-responsiveness (anergy) in the $T$ cell. In fact, this way of producing non-responsiveness may be a mechanism involved in tolerance induction as can be observed after oral immunization. There is no direct evidence however, that in adenotonsillar tissues these second step interactions are inadequate. Immunohistological analysis of human tonsils has shown that the important co-stimulatory molecules $\mathrm{B} 7$ and $\mathrm{CD}-40$ were expressed on DC, macrophages and $\mathrm{B}$ cells, whereas the ligand structures CD28, CTLA4 (another relevant $T$ cell counterpart structure for $B 7$ molecules) and CD40-ligand were present on T cells (10). Thus, most likely, adenotonsillar tissues have competent $\mathrm{APC}$ for activation of $\mathrm{T}$ helper cells upon antigen challenge. That indeed activated or functional $T$ helper cells are present in nasal and nasopharyngeal lymphoid tissues is supported by the observation that $B$ cell follicles with germinal centers (GC) are present in these tissues. Such formation of $G C$, which are essential for $B$ cell memory 
formation and for the $\operatorname{Ig}$ isotype switch from $\operatorname{IgM}$ to for exmple $\operatorname{IgG}$ and $\operatorname{IgA}$, namely requires explicitely the support of T helper cells.

Another aspect helping to understand the immune functioning of adenotonsillar or analogous organs in the rat is to determine which $T$ helper cell subtypes are produced and dominate during the immune response in these organs. This is important since the Th-1 and Th-2 subtypes of $T$ helper cells, each with a specific profile of produced cytokines, regulate different immune responses. Th-1 cells produce the cytokines IL-2 and IFN-g which are required for generating a typical cellular immune response with a dominant role for cytotoxic T cells and macrophages. Th- 2 cells produce IL-4, IL-5, and IL-10, which are relevant for a humoral immune response with production of $\operatorname{IgE}$ and $\operatorname{IgA}$ antibodies in particular. These antibodies play a crucial role in type I hypersensitivity reactions and mucosal immunological protection respectively. Although the pathway along which Th- 1 or Th- 2 cells are generated is not yet understood, APC and macrophages seem to be involved. From studies with tonsil]ar T cells it is suggested that in nasal and nasopharyngeal lymphoid tissues both a Th- 1 and a Th-2 response can occur. Which type of response is generated upon antigen presentation appears dependent on the type of antigen and the route of antigen presentation (11). Ain important regulatory mechanism in this respect is that dominance of a Th-1 response leads to inhibition of the Th-2 response, and vice versa. Such Th-1/Th-2 regulatory phenomena are current fields of interest in research regarding nasal and oral immunization (vaccination) to specifically tolerize the immune system.

For the initiation of an immune response in nasal and nasopharymgeal lymphoid tissues, and also for the propagation of a response from local to systemic levels it is essential that antigenspecific lymphocytes can enter and leave these lymphoid organs. As shown by studies in human nasopharyngeal and rat nasal lymphoid tissues, these organs contain specialized blood vessels, so-called HEV, to support the immigration of recirculating blood lymphocytes $(7,12)$. It appears that lymphocytes from all the various lymphoid organs throughout the body do recirculate through nasal and nasopharyngeal lymphoid tissues. As such, adenotonsillar organs are integrated in the systemic immune system. In the process of lymphocyte extravasation at $\mathrm{HEV}$ a dominant role exists for endothelial and lymphocytic cell adhesion molecules. The process of lymphocyte extravasation can be considered a multistep phenomenon in which at least four essential steps can be defined (13). The first step is the so-called "rolling" of lymphocytes along the endothelial cells of HEV. This is mediated by cell adhesion molecules, so-called homing receptors (such as $\mathbf{L}$-selectin) on lymphocytes and ligand cell adhesion molecules, so-called addressins, on HEV. In the second step, accessory adhesion molecules on lymphocytes, such as "lymphocyte-functional-antigen-1" (LFA-1), become activated and enable binding to the ligand adhesion molecules on HEV, such as "Inter-Cellular-AdhesionMoleculle-1" (ICAM-1) and ICAM-2. As a consequence the lymphocytes are arrested and firmly bound to the HEV (step 3). Subsequently, the fourth step can occur in which the bound lymphocytes acquire motility and migrate through the endothelium of HEV and enter the parenchymal compartment of the lymphoid organ. 
Interestingly, various types of homing receptors and addressins play a role in the migration of lymphocytes through the lymphoid organs of the body: It appears that HEV in mucosal Jymphid tissues express an other addressin than HEV in non-mucosal lymphoid tissues. This allows selective migration of lymphocytes to the various anatomically different lymphoid tissues in the body. With respect to migration of lymphocytes to nasal and nasopharyngeal lymphoid tissues, the addressin MAdCAM-1 ("Mucosal-Addressin-Cell-Adhesion-Molecule17, recognized by mAb MECA-367)(14), may be an important adhesion molecule. It is predominantly expressed on HEV in mucosal lymphoid tissues and binds to the integrin ligand a 467 (another homing receptor) on blood lymphocytes (15). Although for nasal and adenotonsillar tissues more or less unique lymphocyte migration and HEV adherence patterns have been shown, the precise characterization of involved cell adhesion molecules on lymphocytes and HEV awaits further elucidation.

Information on the the routes taken by effector cells and products from nasal and nasopharyngeal lymphoid organs is essential for understanding the possible impact of these organs on the systemic immune response. Lymph drainage studies in rat and pig have shown the cervical lymph nodes to be an important station in lymph drainage from nasal and nasopharyngeal tissues $(7,16)$. Apparently these cervical lymph nodes play the same role in propagation of the adenotonsillar immune response as the mesenteric lymph nodes play in propagation of the Peyer's patch response. Lymphocyte migration and $\mathrm{HEV}$ adherence studies in the rat showed that lymphocytes from nast] and nasopharyngeal lymploid organs can migrate to all lymphoid organs throughout the body $(7,13)$. Interestingly, these studies showed that lymphocytes from the nasal lymphoid organs migrated, in comparison to lymphocytes from other lymphoid tissues, in relatively high intensity to the liver (1). These data demonstrate that an immune response initiated in nasal and nasopharyngeal lymphoid organs can be systemically propagated. In this respect it is essential to mention that striking differences exist between migration patterns of naive lymphocytes (no antigen encountered) and memory or antigen-activated lymphocytes. Whereas naive cells in general migrate to al lymphoid organs, memory and antigen-activated cells migrate selectively to locations of antigen exposure (the inflammatory sites) and to the lymphoid organs related to the site of initiation of the immune response. How precisley activated/menory cells from adenotonsillar tissues migrate is an issue of importance that needs further elucidation.

In summary it can be stated that nasal and nasopharyngeal lymphoid tissues form a distinct group of mucosa associated lymphoid tissues involved in local and systemical immune responses to inhalatory antigens. The various studies performed so far were predominantly in human and were of a characterizing nature. In this study a WR equivalent in the rat is described, that appears to be a well organised MALT structure with unique functional features with respect to lymphocyte migration pattern. Characteristics of both lymph node and Peyer's patch were recognised. The experimental rat model described in this thesis may importantly contribute to unraveling the immunollogical processes in nasal and nasopharyngeal lymphoid tissues. Precise knowledge about their immunological function will help to understand local diseases related to these organs and to define possible (immuno)therapeutical approaches. 


\section{References}

1. Koornstra PJ, de Jong FICRS, Vlek LFM, Marres EHMA, van Breda Vriesman PJC. The Waldeyer Ring equivalent in the rat. Acta Otolaryngol. (Stockh) 1991; 111:591-599.

2. wan Cauwenberge PB, Bellussi L, Maw AR, Paradise JL, Solow B. The adenoid as a key factor in upper airway infections. Int J Ped Otol Rhinol Laryngol 1995; 32 suppl :71-80.

3. Cantani $A$, Bellioni $P$, Salvinelli $F$, Businco L. Serum Immunoglobulins and secretory lgA deficiency in tonsillectomized children. Ann Allergy 1986;57.

4. Sainz M, Gutierrez $F$, Moreno PM, Munoz C, Ciges $M$. Changes in immunologic response in tonsillectomized children. Clin Otolaryngol 1992; 17:376-379.

5. Passàli D, Fokkens WJ, van Cauwenberge PB, Ferrara A, Scadding GK. Allergy in children. Int J Ped Otol Rhinol Laryngol 1995; 32 suppl 81-86.

6. Brandtzaeg P, Halstemen TS. Immunology and immunopathology of the tonsils. Adv Otol Rhinol. Laryngol 1992; 47: 64-75.

7. Koornstra PJ, Duijvestijn AM, Vlek LFM, Marres EHMA, van Breda Vriesman PJC. Acta Otolaryngol (Stockh) 1993; 113: 660-667.

8. Neutra MR, Frey A, Kraehenbuhl JP. Epithelial M cells: gateways for mucosall infection and immunisation. Cell 1996; 86: 345-348

9. Bluestone JA. New perspectives of CD28-B7 mediated T cell costimulation. Immunity 1995; 2: $555-559$.

10. Vyth-Dreeze FA, Dellemijn TA, Majoor D, de Jong D. Localisation in situ of the costimulatory molecules B7.1, B7.2, CD40 and their ligands in normal lymphoid tissue. Eur J Immunol $1995 ; 25: 3023-3029$.

11. Martinez-Arends A, Astoul E, Lafage M, Lafon M. Activation of human tonsil lymphocytes by rabies wirus nucleocapsid superantigen. Clin Immunol Immunopathol 1995; 77: 177-184.

12. Koornstra PJ, Duijuestijn AM, Vlek LFM, Marres EHMA, van Breda Vriesman PJC. Tonsillar (Waldeyer's Ring equivalent lymphoid tissue in the rat: Iymphocyte subset binding to High Endothelial Venules(HEV) and in situ distribution. Reg Immunol 1992; 4: 401-408.

13. Girard JP, Springer TA. High Endothelial Venules (HEV"s): specialised endothelium for lymphocyte migration. Immunol Today 1995; 16: 449-457.

14. Streeter PR, Berg EL, Rouse BN, Bargatze RF, Butcher EC. A tissue-specific endothel ial cell molecule involved in lymphocyte homing. Nature $1988 ; 331: 41-46$. 
15. Erle D, Briskin M, Butcher EC, Garcia-Pardo A, Lazarovits Al, Tidswell M. Expression and function of the MAdCAM-1 receptor, integrin alfa4beta7 on human leukocytes. I Immunol $1994 ; 153: 517-528$.

16. Beltz $\mathrm{GH}$, Heath TJ. Lymphatie drainage from the tonsil of the soft palate in pigs. J Anatomy $1995 ; 187: 491-495$. 
SUTMMARY 


\section{Summary}

In this thesis the development of an experimental rat model for studying the immunological role of oro-nasopharyngeal lymphoid tissue was described. No distinct pharyngeal lymphoid tissue (equivalent to the tonsils of man) was found in the rat, but as described in chapter 1, a typical rod-shaped lymphoid organ, was observed bilaterally in the wall of the posterior part of the nose. These two parachoanic (nasal) lymphoid organs were, since no other distinct lymphoid tissues were detected in nasopharymx, considered the rat Waldeyer's ring equivalent (WRE), of man, and now are designated nasal associated lymphoid tissue (NALT). The experimental data obtained in this rat NALT/WRE model were presented in the chapters 2 to 5 of this thesis.

In chapter 2 the systemic and topographic anatomy of these organs were described, as well as the surgical approach to get access to NALT/WRE for short term in vivo experiments and for extirpation of the organs in toto. It was shown that the blood supply originated from the internal carotid artery and that the lymphatics drained directly into the deep cervical lymph nodes. Light microscopy showed NALT/WRE to be lined by respiratory epithelial cells. This was confirmed by electron microscopic studies, that revealed characteristic "pits" in the epithelial surface, which were identified as fieldis of distinct so-called $M$ cells. These M cells are held to be responsible for uptake of particulate antigen from the respiratory lumen. Studies with the extirpated organs showed that NALT/WRE grows relatively rapidly is seize and weight during the first 8 weeks of life, peaking at 11 weeks. Then, with sexual maturity it declines in seize and weight but not to the extent of complete involution or atrophy.

In order to demonstrate that NALT/WRE is indeed mucosa associated lymphoid tissue, in chapter 3 immunohistochemical studies were carried out to identify lymphoid and nonIymphoid cell types. It was shown that in NALT/WRE the T and B cells were compartimentalised in distinct areas. As in other mucosa associated lymphoid tissues, the B cell areas were located directly underneath the mucosal epithelium and had a preponderance over the T cell areas which were located at the abluminal side in the interfollicular areas. These $T$ cell areas consisted of CD4, CD8 and MHC class II positive dendritic cells, and in addition contained specialized high endothelial venules (HEV). The B cell areas contained follicles with germinal centers in which follicular dendritic cells and scattered CD4 T cells were observed. NALT/WRE also contained plasma cells, notably of the IgA type, located at the abluminal side of the organ. Thus, as studied so far by immunocytochemistry, the NALT/WRE can be considered a typical mucosa associated lymphoid organ.

In chapter 4 the question was addressed whether NALT/WRE functionally differs or resembles other mucosa associated lymphoid organs such as the Peyer's patches of the small bowel, and if it potentially may influence the systemic immune reponse. The approach chosen was to study the migratory behaviour of lymphocytes from NALT/WRE to other lymphoid organs and vice versa. In NALT/WRE the presence of HEV was demonstrated and, since others have shown that HEV in lymphoid organs express organ-specific adhesion molecules for lymphocytes, it was speculated that organ-specific migration patterns of lymphocytes from and to 
NALT/WRE could exist. Therefore, lymphocytes of rat lymph nodes, Peyer's patches, NALT/WRE and thoracic duct were isolated, radiolabelled with $51 \mathrm{Cr}$, and next infused into recipient rats in order to monitor their migratory potential in vivo. FACS analysis had quantitated that NALT/WRE contained, as found for other mucosa associated lymphoid organs, a preponderance of $B$ over $\mathbb{T}$ cell $s$, and in this respect lymphocyte migration patterns for NALT/WRE were expected to resemble those for Peyer's patches. It appeared that lymphocytes of NALT/WRE homed well into all lymphoid organs (e.g. NALT/WRE, lymph nodes, Peyer's patches and spleen). In contrast to lymphocytes from lymph nodes, NALT/WRE lymphocytes homed relatively well into the liver and in this respect were most resembling lymphocytes from Peyer"s patches. The T cell migration from NALT/WRE differs, however, from that of Peyer's patches in showing larger migration rate to NALT/WRE and peripheral (e.g. cervical) lymph nodes. Thus in terms of migratory behaviour, NALT/WRE tumed out to be rather unique in sharing on one hand characteristics with peripheral node lymphocytes and on the other hand with mucosa associated (Peyer's patch) lymphocytes. These observations could be explained in a variety of fashions including a possible difference in composition in the population of NALT/WRE lymphocytes, or a difference in HEV characteristics of NALT/WRE.

In chapter 5 this issue has been addressed by studying in vitro the adherence of lymphocytes to HEV in frozen tissue sections of NALT/WRE and other lymphoid organs. Lymphocytepopulations used for adherence studies were analysed for present subsets using FACS analysis. The populations were then allowed to bind to HEV in frozen tissue sections, and subsequently the lymphocytes bound to $\mathrm{HEV}$ were sub-typed by immunofluorescence staining on the sections. The data showed that lymphocyte adherence to the HEV in NALT/WRE is equal to binding to HEV in lymph node, and superior to binding to Peyer"s patch HEV. T cells adhere better than B cells to HEV in NALT/WRE, in spite of the fact that NALT/WRE contains more B cells than T cells. Also for CD8 cells it was found that they bound better than CD4 cells, whereas in situ many more CD4 than CD8 cells are found in NALT/WRE. Thus the phenotypic lymphocyte subset profile of NALT/WRE does not reflect HEV binding. The T-B cell binding ratio observed for HEV in NALT/WRE is unique since in other lymphoid organs this binding rellected in situ composition. For CD4/CD8 binding the noticed discrepancy with in situ distribution of CD4 and CD8 cells in NALT/WRE was also found, although less distinet, for the other lymphoid organs. The observation that $T$ cells bind better to NALT/WRE HEV than B cells, possibly regulated by specific adhesion molecules on the $\mathrm{HEV}$, suggests a prevalence of $\mathrm{T}$ cell immigration. It may in addition indicate a significant role of $T$ cells and in particular of $\mathrm{CD} 8$ cells in the immune function of NAL.T/WRE. 
SAMENVATTING 


\section{Samenvatting}

In dit proefschrift wordt de ontwikkeling van een experimenteel (rat) model ter bestudering van de immunologische rol van oro-nasopharyngeaal lym foìd weefsel beschreven. In de rat werd geen pharyngeaal lymfoïd weefsel (equivalent aan de humane tonsil) gevonden, maar zoals beschreven in hoofdstuk I werd een staafvormig lymfoïd orgaan bilateraal aan de wand, posterieur in de neus geobserveerd. Aangezien geen ander georganiseerd lymfö̈d weefsel in de nasopharynx werd gevonden worden deze twee parachoanale (neus) lymfö̈de organen beschouwd als het Waldeyers ring equivalent (WRE) van de mens en worden in de literatuur beschreven als neus geassocieerd lymfoild weefsel (NALT). De experimentele data, verkregen uit dit NALT/WRE onderzoek, worden in de hoofdstukken 2 tot en met 5 van dit proefschrift beschreven.

In hoofdstuk 2 wordt zowel de anatomie van deze organen beschreven als ook de chirurgische benadering. Met deze chirurgische benadering wordt toegang verkregen tot het NALT/WRE woor zowel kortdurende in vivo experimenten als voor het verwijderen van de organen in toto. De bloedvoorziening van het NALT/WRE heeft zijn origine in de arteria carotis interna. De afvoerende lymfevaten draineren direct in de diepe cervicale lymfeklieren. Licht microscopie liet zien dat het NALT /WRE bekleed was met respiratoire epitheliale cellen. Dit werd bevestigd door elektronen-microscopische studie. Deze studie liet karakteristieke "pitts" in het epitheliale oppervlak zien, welke geîdentificeerd werden als de zo genoemde $M$ cellen. Deze $M$ cellen worden verantwoordelijk gehouden woor de opname van antigeen partikels vanuit het respiratoire lumen. Studie naar het NALT/WRE laat zien dat deze organen relatief snel groeien in afmeting en gewicht gedurende de eerste acht levensweken en hun piek bereiken bij 11 weken. Bij volledige sexuele rijpheid van het dier neemt het NALT/WRE in omvang en gewicht af, maar niet zodanig dat van involutie of atrofie gesproken kan worden.

Om aan te tonen dat NALT/WRE inderdaad mucosa geassocieerd lymfoïd weefsel is, werden in hoofdstuk 3 immunohistochemische studies uitgevoerd om lymfoïde en niet lymfoïde celtypen te identificeren. Er werd aangetoond dat in het NALT /WRE de $T$ en $B$ cellen gecompartimentaliseerd zijn in verschillende gebieden. Net zoals bij ander mucosa geassocieerd lymfoid weefsel zijn bij het NALT/WRE de B cel gebieden direct onder het mucosale epitheel gelegen en zijn zij groter in aantal dan de T cel gebieden, welke gelegen zijn aan de niet lumen zijde interfolliculaire gebieden. Deze T cel gebieden bevatten CD4, CD8 en MHC classe II positieve dendritische cellen. Daarnaast bevatten zij nog gespecialiseerde hoge endotheliale venulen (HEV). De B cel gebieden bevatten follikels met kiemcentra waarin folliculaire dendritische cellen en verspreid liggende CD4 T cellen werden geobserveerd. Het NALT/WRE bevatte ook plasma cellen met name het IgA type. Deze waren gelokaliseerd aan de niet lumen zijde van het orgaan. Deze immunohistochemische studie laat zien dat het NALT/WRE beschouwd kan worden als een mucosa geassocieerd orgaan.

In hoofdstuk 4 werd de vraag gesteld of het NALT/WRE functioneel verschilt of juist lijkt op andere mucosa geassocieerde organen zoals de plaques van Peyer uit de dunne darm, en of het NALT/WRE invloed heeft op de systemische immuun respons. Om dit te onderzoeken hebben 
We gebruik gemaakt van migrafie studies van lymphocyten afkomstig uit het NALT/WRE naar ander lymfoide organen en vise versa. In het NALT/WRE was de aanwezigheid van HEV aangetoond. Anderen hebben aangetoond dat HEV in lymfoide organen orgaan specifieke adhesie moleculen voor lymphocyten tot expressie brengen. Gespeculeerd werd dat er orgaan specifieke migratie patronen van lymphocyten van en naar het NALT/WRE zouden kunnen bestaan. In dat kader werden lymphocyten uit lymfeklieren, plaques van Peyer, NALT/WRE en ductus thoracicus van de rat geisoleerd. Deze werden radioactief gelabeld met $51 \mathrm{Cr}$ en vervolgens ingespoten in acceptor ratten om zo hun migratie potentiaal te monitoren. FACS analyse kwantificeerde in het NALT/WRE meer B dan T cellen. Dit is in overeenstemming met data van FACS analyse bij de andere mucosa geassocieerde lymfö̈de organen. Dit wekt de verwachting dat het lymphocyt migratie patroon van het NALT/WRE lijkt op die van de plaques van Peyer. Het bleek dat lymphocyten afkomstig uit het NALT/WRE goed naar jymfoilde organen homen (zoals NALT/WRE, lymfeklieren, plaques van Peyer en milt). In tegenstelling tot lymphocyten afkomstig wit lymfeklieren homen lymphocyten afkomstig uit het NALT/WRE relatief goed naar de lever en lijken hiermee het meest op lymphocyten afkomstig uit de plaques van Peyer. De migratie wan T cellen afkomstig uit het NALT/WRE verschilt daarentegen van die van T cellen afkomstig uit plaques van Peyer. T cellen afkomstig uit het NALT/WRE vertonen een hogere mate van migratie naar het NALT/WRE en perifere (b.v. cervicale) lymfeklieren. Met betrekking tot het migratie patroon lijkt het NALT/WRE uniek te zijn; het heeft enerzijds karakteristieken passend bij lymphocyten afkomstig uit perifere lymfeklieren en anderzijds karakteristieken passend bij lymphocyten afkomstig uil mucosa geașsocieerde (b.v. plaques van Peyer) lymfoỉde organen. Deze observaties kunnen verklaard worden door een verscheidenheid aan mogelijkheden zoals een mogelijk verschil in samenstelling van de populatie van de NALT/WRE lymphocyten, of een verschill in HEV eigenschappen van het NALT/WRE.

In hoofdstuk 5 wordt de binding van lymphocyten door studies van in vitro binding van lymphocyten aan HEV's in vriescoupes van het NALT/WRE en andere lymfoïde organen beschreven. Lymphocyten populaties, welke gebruikt werden voor binding studies, werden geanalyseerd op aanwezige lymphocyten subsets door middel van FACS analyse. De populatie lymphocyten werd vervolgens gebonden aan de HEV's van de lymfoïde organen. De gebonden lymphocyten werden gesubtypeerd door immunofluorescentie kleuring op de coupes. De data laten zien dat lymphocyten binding aan de HEV in het NALT/WRE gelijk is aan lymphocyten binding aan $\mathrm{HEV}$ in lymfeklieren, maar dat deze beter is dan binding aan HEV van de plaques van Peyer.Ondanks dat het NALT/WRE meer B cellen dan T cellen bevat, hechtten T cellen beter dan $\mathrm{B}$ cellen aan HEV in het NALT/WRE. Ook voor CD8 positieve cellen werd gevonden dat zij beter binden dan CD4 positieve cellen, ondanks dat in situ in het NALT/WRE meer CD4 dan CD8 positieve cellen aanwezig zijn. Het phenotypische lymphocyten profiel van het NALT/WRE reflecteert niet de HEV binding. De T-B cel bindings ratio van HEV in het NALT/WRE is uniek ten opzichte van andere lymfolde organen omdat de T-B cel bindings ratio niet de in situ compositie reflecteert. Met betrekking tot CD4/CD8 binding werd ook een discrepantie gezien tussen binding en de in situ distributie bij het NALT/WRE maar voor andere organen minder uitgesproken. De observatie dat T cellen beter aan HEV van het NALT/WRE binden dan B cellen, mogelijk gereguleerd door specifieke adhesie moleculen op de HEV, suggereert een 
voorkeur van $\mathrm{T}$ cel immigratie. Het kan een sigmificante rol van de $\mathrm{T}$ cellen, en in het bijzonder van CD8 cellen betekenen, in de immunologische functie van het NALTTWRE. 


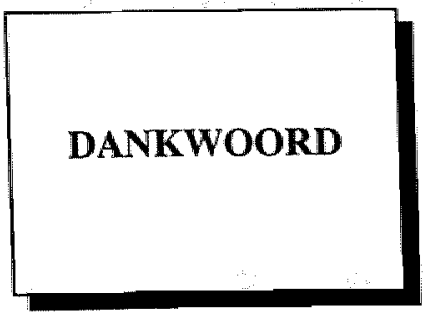


Dit dankwoord biedt mij de gelegenheid om te benadrukken dat mijn proefschrift geen éénmans productie is geweest. Velen droegen bij aan mijn onderzoek, aan het bewerken van de resultaten, aan het schrijven en herschrijven van het boekje en aan het scheppen van een structurur waarin dit alles mogelijk is geweest.

ledereen wil ik bedanken die er op enigerlei wijze aan heeft bijgedragen, vooral degene(n) die ik op dit moment vergeet apart te vermelden.

Hooggeleerde Prof. Dr. P.J.C. van Breda Vriesman, beste Peter, jouw kennis en creativiteit stonden borg voor een stroom aan originele ideeên waarvan ik er slechts enkele heb kunnen uitwoeren. Naar jouw inzicht ongetwijfeld de minst interessante! Desondanks verschafte je mij langdurig personele ondersteuning.

Prof. Dr. E.H.M.A. Marres, beste Ed, ik dank je voor mijn opleiding tot KNO-arts, voor het scheppen van een klimaat waarin de basis voor dit proefschrift kon worden gelegd. Je oprechte belangstelling heeft mij steeds gestimuleerd.

In het bijzonder dank ik mijn copromotores dr. F.I.C.R.S. de Jong en dr. A.M. Duijvestijn. Beste Felix, het onderzoek waaruit dit proefschrift voortkwam is door jou gestart. We hebben uren boven de microscoop gehangen waarbij je me de weg wees naar het Waldeyer ring equivalent. Veel tijd werd doorgebracht met het berekenen en bediscussiëren van de experimenten. Aan het eind van de rit hebben we samen de tekst doorgewerkt en achter de computer geprobeerd om onze tabellen nog mooier te maken. Met je persoonlijke inzet en je optimisme wist je mij telkens weer te inspireren waarvoor mijn dank.

Thia, ik heb Felix vele dagen van je mogen lenen en intensief van je gastvrijheid gebruik gemaakt. Ik waardeer dit bijzonder!

Beste Ad, toen Felix vertrok nam jij de begeleiding van het onderzoek enthousiast van hem over. Ik heb dankbaar gebruik gemaakt van je deskundigheid op lymfocytadherentie. $\mathrm{Na}$ mijn vertrek uit Maastricht hing je vaak langdurig aan de telefoon. Slechts door resultaten toe te zeggen en deadlines te accepteren kon ik je afschudden. Tegelijkertijd wist ook jij uit te stralen dat een boekje binnen mijn bereik lag.

De medewerkers van de afdeling Immunologie ben ik dankbaar voor hun hulp en kameraad schap.

Wineke Vlek, samen hebben we uren aan de werkbank gestaan. Jij hebt me ingewerkt in de wereld van pipetten en cellen. Ik vind het. een eer je als paranymph naast me te hebben. Henk van Rie, je hulp bij het uitvoeren van de vele kleuringen, fluorescentie microscopie, fotografie en bij het archiveren waren onontbeerlijk.

Een bijzonder woord van dank aan Prof. Dr. J. Drukker voor de geboden faciliteiten en de prettige wijze waarop U Uw kritiek op het manuscript naar voren bracht.

Medewerkers van de van de vakgroep Anatomie wil ik danken voor hun gastvrijheid en de verleende assistentie.

Paul van Dijk Johan Hekking, Arno Lataster en Hans Rensema dank voor jullie medewerking en suggesties. 
Bert Schutte en Michelle dank voor jullie deskundigheid en hulp bij de FACS analyses.

Dr. P. Frederics ben ik erkentelijk woor zijn hulp bij het bekijken van de EM foto's.

Medewerkers van de vakgroep elektronenmicroscopie met name Paul wil ik danken woor hun enthousiaste ondersteuning.

Prof. Dr. J.J. Woodruff. I would like to thank you for the given opportunity to work in your lab and to learn all about lymphocyte adhesion. Michael, Denise and Juran thanks for being my colleagues and making fun in and outside the lab.

Anita en Anouk wil ik danken voor secretariële ondersteuning.

Francien Teng, jou wil ik danken voor je adminisratieve hulp, assistentie bij het gebruik van de tekstverwerker en de gezelligheid daaromheen.

Verder mijn dank aan de medewerkers van de vakgroep medische Fotografie en aan de medewerkers van de afdeling proefdiervoorziening.

Een belangrijke impuls om verder te gaan gaf Jan Dulfer, reklame fotograaf te Vlaardingen met zijn foto's en dia's.

Marco van Haren wist weerspannige hardware en software met elkaar te verzoenen en de layout van de tekst kloppend te maken.

Paul van der Linden, fijn dat ik in deze laatste ronde op je hulp kan rekenen. Bedankt voor je vriendschap.

Mijn moeder, mam bedankt voor alles!

Alma , Marja en Genevieve bedankt voor de opvang van de kinderen.

Rolf zal ik later op een andere manier bedanken.

Barbara en Bas, vanaf heden mogen tabellen en tekstvellen wel door jullie ingekleurd en in vliegtuigen veranderd worden.

Mooit had dit proofschrift or kunnen komen zonder do vele ratten die er letterlijh hun leven woor gaven. 


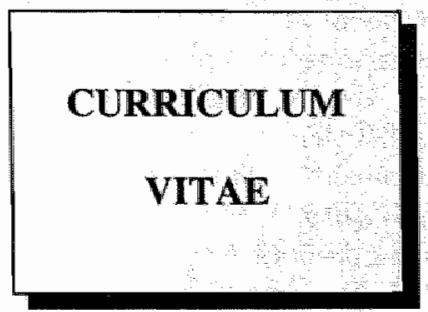




\section{Curricullum vitae}

Petra Koornstra werd geboren op 2 maart 1957 te Eindhoven.

In 1976 behaalde zij aan het Koninklijk Atheneum te Tongeren, België, het diploma Atheneum, studierichting wetenschappelijke B.

Van 1978 tot 1984 studeerde zij Geneeskunde aan de Rijksuniversiteit Limburg.

Aansluitend verrichtte zij voor de vakgroep Algemene Heelkunde van het Academisch Ziekenhuis Maastricht (Hoofd: Prof. Dr. J.M. Greep), o.l.v. Prof. Dr. J.W.J.L. Stapert en Dr. C.R. van den Hoogenband gedurende 1 jaar klinisch onderzoek naar vroege mobilisatie van midschacht femurfracturen bij kinderen en was zij betrokken bij het opstarten van een prospectief onderzoek naar behandelingsresultaten van enkelfracturen .

In juli 1986 trad zij in dienst van de vakgroep Keel-, Neus- en Oorheelkunde aan de Universiteit Maastricht. In nauwe samenwerking met de vakgroep Immunologie van deze universiteit werd onder leiding van Prof. Dr. P.J.C. van Breda Vriesman in deze periode een aanvang gemaakt met onderzoek naar het oro-nasopharyngeale immuunsysteem bij de rat, hetgeen resulteerde in dit proefschrift.

Van januari tot julli 1987 was zij als research fellow werkzaam op de afdeling Pathologie van de State University New York, Brookllyn, New York waar zij onderzoek deed naar adherentie van lymfoìce cellen onder leiding van Prof. Dr. J.J. Woodruff.

Van 1 juli 1987 tot 1 juli 1991 werd zij door Prof. Dr. E.H.M.A. Marres in het Academisch Ziekenhuis Maastricht opgeleid tot Keel-, Neus- en Oorarts. Te Roermond en Sittard beoefende zij vervolgens de $\mathrm{KNO}$-heelkunde in respectievelijk het Maasland en het Laurentius ziekenhuis. Terzelfdertijd werd het promotieonderzoek te Maastricht voortgezet. Van 1 juli 1992 tot 1 oktober 1995 voerde zij een KNO-praktijk in het Ruwaard van Putten Ziekenhuis te Spijkenisse.

Momenteel is zij als consulent KNO-arts onder andere verbonden aan de Koninklijke Ammanstichting te Rotterdam. 